\title{
A tegzesek (Trichoptera) kutatásának eredményei a Dráva hazai vízgyüjtőjén az elmúlt negyven évben
}

\author{
UHERKovich ÁKos \& NóGrÁdi SÁRA
}

H-7633 Pécs, Építők útja 3/b. I. 6. e-mail: uhu941@gmail.com

\begin{abstract}
Uherkovich Á. \& NóGrÁDi S.: Results of caddisfly (Trichoptera) examination in the Hungarian catchment area of Drava river (SW Hungary) during the last forty years.

Abstract: 143 caddisfly species were documented in the investigated area during the past forty years. 98 of them lived along the main branches of Drava and Mura river. In the richest subregion, alongside Kerka river and tributaries, 108 species were detected. Only single adult of Micrasema setiferum (Pictet, 1834) and Hydroptila pulchricornis Pictet, 1834 was collected also here. Helicopsyche bacescui Orghidan \& Botosaneanu, 1953 was recorded only in this area in SW Hungary, and most of the total known specimens of Platyphylax frauenfeldi Brauer, 1857 were taken along the Drava river and its catchment area. This latter species is strictly protected, and also protected ones are Limnephilus elegans Curtis, 1834, Oligotricha striata (Linnaeus, 1758) and Rhyacophila hirticornis McLachlan, 1879. The western part of Drava river and its catchment area is rich in caddisfly species in Hungary.
\end{abstract}

Keywords: Caddisfly, Trichoptera, Drava, SW Hungary, faunistics, nature conservation

\section{Bevezető}

\section{A Dráva hazai vízgyüjtője}

A Dráva teljes vízgyújtője $43238 \mathrm{~km}^{2}$-en terül el, ennek csaknem egyötöde (19,95\%, $8431 \mathrm{~km}^{2}$ ) jut hazánk területére. A vízgyüjtő a Délnyugat-Dunántúl jelentős területét elfoglalja. Legnagyobb mellékfolyója a Mura, amelyet néhány bővebb vizü folyó és patak táplál hazánkban is (például Kerka, Cserta). Magába a Drávába csak kisebb vizek ömlenek a magyarországi szakaszon, ezek vízhozama a folyóhoz képest elenyésző.

Alacsony domb- és síkvidéki karakterü folyó, csak a Mecsek délnyugati részén, kis területen emelkedik a térszín 5-600 méterig (Jakab-hegy, Tubes-Misina-csoport). Az itt fakadó és végső soron a Drávába ömlő kisebb patakok jellemzően 150-300 méteres magasságban folynak.

A Dráva közepes vízhozama - a Murával való egyesülés alatt - $600 \mathrm{~m}^{3} / \mathrm{sec}$. A vízjárás viszonylag egyenletes, azonban a horvátországi vízierőmüvek napszakos müködése miatt a Dráva magyarországi szakaszán, Örtilos környékén a napi vízszint-ingadozás jelentős (közel 100 centiméteres) Ez az ingadozás a hazai szakaszon lefelé haladva jelentősen csökken. A folyó vízminősége hazai nagyobb folyóink közül itt a legjobb.

A vízgyüjtő nyugati és középső része meglehetősen csapadékos, ott az évi átlagos csapadékösszeg akár 750-800 mm is lehet. Délkelet felé ez mintegy $600 \mathrm{~mm}$-re csökken. 


\section{Rövid kutatástörténet}

Először Ujhelyi Sándor gyüjtött tegzeseket a területen a múlt század hetvenes éveiben, részben a Barcsi Tájvédelmi Körzet szervezett kutatása keretében, részben pedig a szombathelyi Savaria Múzeum által szervezett Örség-kutatás programjában. Az első, területre vonatkozó publikációk is az ő nevéhez füződnek (UJHELYI 1981a, 1981b).

Szerzők a nyolcvanas évek eleje óta folytattak intenzív kutatásokat a vízgyüjtőn. Ezek eredményeit több publikációban adták közre. Elsőként a Barcsi TK volt vizsgálatuk tárgya (NóGRÁDI 1985a), később ezt kiterjesztették a Dráva mentére (UHERKOVICH, NóGRÁDI 1992b, UhERKOVICH 2005), valamint az Örségre is (UHERKOVICH, NóGrÁDI 1992a). A Mura és Kerka vízrendszerét ugyancsak tanulmányozták (NóGRÁDI, UHERKOVICH 2002b), ugyanígy a Mecsek délnyugati, a drávai vízgyüjtőhöz tartozó részét is (UHERKOVICH, NóGRÁDI 2006). A Zselicben végzett gyüjtőmunka kiterjedt ehhez a vízgyüjtőhöz tartozó dél-zselici vidékre is (NóGRÁDI, UHERKOVICH 1990). Kisebb, itt most fel nem sorolt (de az irodalomjegyzékben szereplő) cikkek ugyancsak ismertettek előfordulási adatokat a vízgyüjtőről. A Dráva vízgyüjtőjén kívül az ország számos más vizét illetve tájegységét is kutatták a szerzők, ezek eredményeit itt nem részletezik.

\section{Anyag és módszer}

\section{Módszerek}

Nappali hálózás segítségével elsősorban a nappal aktív fajokat gyüjtöttük. Az aljnövényzet vagy a vízparti cserjék, belógó lombozat hálózásával ugyanakkor az éjjel aktív, nappal itt pihenő imágókat is fogtuk. Tipikusan nappali aktivitású fajok: Brachycentrus subnubilus, Oligostomis reticulata, Lithax obscurus, Hagenella clathrata, ez utóbbi néha fényre is repül.

Mind fajok, mind pedig a példányok számát tekintve a legeredményesebb gyüjtési módszer a fényen történő gyüjtés. Személyes gyüjtésnél - amelyet általában „lámpázásnak" neveznek a rovarászok - többnyire 230 V 125 vagy 250 wattos higanygőzlámpa a fényforrás, ezeket általában hordozható áramfejlesztő látja el árammal. Az éjjel aktív tegzesek pozitív fototaxisát használjuk ki ezzel. Egy-egy ilyen lámpázás során kedvezőbb esetekben akár 30-40 faj is megjelenik a gyüjtőlepedőn, a beérkező példányok száma olykor több tízezerre tehető. Két gyüjtő 3-4 óra alatt legfeljebb 3-4000 példányt tud eltenni és konzerválni a későbbi feldolgozás számára. Sokszor felkeresett helyek személyes éjjeli gyűjtés céljából: Drávapalkonya, Vejti, Drávasztára, Pécs-Deindol, Hetvehely, Szentborbás, Barcs (Rinya-Ó-Dráva), Vízvár, Bélavár, Somogyudvarhely, Örtilos, Muraszemenye, Kerkaszentkirály, Kercaszomor, Magyarszombatfa. Az összes gyüjtőhelyet az 1. táblázat tartalmazza.

Az automata fénycsapdák egy-egy éjszakai mintája általában kevesebb fajt illetve példányt tartalmaz, szakember jelenlétét nem kívánja. Müködési ideje folyamatos lehet a teljes aktivitási időszakban (május-november), vagy legalábbis havonta 5-10 napon keresztül, ezért óriási mennyiségú anyagot eredményezhet. Így például Szentborbáson, a Dráva-parton álló fénycsapda több mint húszezer, az örtilosi - ugyancsak a Dráva partjára telepített csapda - pedig mintegy száztízezer tegzes imágót fogott. Emellett még Magyarszombatfán, Vízváron és Szentpéterföldén - ez utóbbi az ERTI (Erdészeti Tudományos Intézet) kezelésében - volt fontosabb csapdánk. A csapdákban általában 80 wattos higanygőzlámpa világított.

Hordozható fénycsapdát több helyen használtunk, rendszerint a személyes gyüjtés kiegészítésére vagy pedig önmagában is. Az áramfejlesztő közelségében különbözö 
$(80 \mathrm{~W}, 125 \mathrm{~W}$ vagy $160 \mathrm{~W})$ higanygőzlámpt használtunk. Áramfejlesztőtől és villamos hálózattól távol pedig alacsony feszültségü fénycsöveket alkalmaztunk a csapdákban, ezeket akkumulátorról tápláltuk.

\section{Lelöhelyek}

Számos lelőhelyen csak alkalmi gyüjtést végeztünk (amely egy-két faj kevés példányát eredményezte). Az anyag túlnyomó hányadát a rendszeresen felkeresett éjjeli gyüjtőhelyeken gyüjtöttük be, illetve a telepített fénycsapdák anyagai között találtuk. Több helyen állt fénycsapda, igen jelentős faj- és egyedszámú anyaggal, több ezer, több tízezer vagy esetleg százezret is meghaladó mennyiségü feldolgozott tegzessel. Az előző bekezdésekben a legfontosabb, rendszeres mintavételi helyünket megemlítettük. Az eredeti feljegyzésekben az itt közöltnél kissé részletesebb lelőhelyi feljegyzések voltak, ezek közül az azonos település határában lévő, egymástól legfeljebb néhányszáz méterre fekvő, hasonló biotópban lévő lelőhelyet összevontunk. A lelőhelyek elnevezését és földrajzi koordinátáit (legközelebbi fokpercre kerekítve) az 1. táblázat sorolja fel.

\section{Gyüjtemény, dokumentáció}

Gyüjteménybe került lehetőség szerint minden lelőhelyről, az összes fajból több-kevesebb példány. A fénycsapdák számtalanszor ismétlődő, tömeges fajai példányainak csak egy kisebb részét őriztük meg. A gyüjteményi anyag legnagyobb részét a pécsi Janus Pannonius Múzeumban és a kaposvári Rippl-Rónai Múzeumban őrzik. Reprezentatív anyagok kerültek a Naturmuseum Senckenbergbe (Frankfurt a/M.), a Smithsonian Institutionba (Washington), Hans Malicky (Lunz am See) gyüjteményébe és a budapesti Magyar Természettudományi Múzeum Állattárába. A gyújteményi példányok túlnyomó részét alkoholos fiolákban konzerváltuk (izopropil- vagy etilalkohol); a tüzött, montírozott példányok száma csekély, ezeket a Janus Pannonius Múzeumban őrzik. A szerzők saját gyüjteményt nem tartanak fenn.

A teljes feldolgozott anyag elsődlegesen a szerzők kézzel írt terepnaplóiban található, amelyek jelenleg még saját birtokukban vannak. Az adatok a kilencvenes évek második felétől - visszamenőleg is - a szerzők adatbázisába kerültek, de ugyanezen adatokat átadták a linzi természettudományi múzeum adatbankjának (ZOBODAT) - ahol bizonyos feltételekkel hozzáférhetők -, illetve a nemrég megjelent Distribution Atlas of Europaean Trichoptera (Neu et al. 2018) adatbázisa illetve nemrég megjelent nyomtatott verziója részére is.

\section{Eredmények}

Ebben a fejezetben az egyes fajokra vonatkozó irodalmi forrásokat, valamint az eddig nem közölt adatainkat adtuk közre. A lelöhelyek közül több, hasonló élőhelyen lévő, egymáshoz közel (t. k. 1 km-en belül) fekvőt összevontuk. Ezt a tényt is megadtuk az 1. táblázatban, annak 7. oszlopában. Ugyanebben a táblázatban jeleztük azokat az irodalmi forrásokat, amelyek az adott lelőhelyre (illetve lelőhely-csoportra) vonatkoztak. A lelőhelyek koordinátáit egész percre kerekítve adjuk meg (az eredeti adatbázisokban ezek másodperc pontossággal szerepelnek), és ugyancsak megadtuk a régebben is használt UTM gridet.

A munkáinkban korábban használt rendszertani beosztást és nevezéktant követjük, ahogy egyébként az európai „Atlaszban” is szerepelnek az egyes fajok illetve családok (MALICKY 2004). 
Az egyes fajoknál elöször a már publikált lelöhelyi adatokat idézzük, majd egy hosszú kötőjellel elválasztva az eddig nem közölt elöfordulásokat adjuk meg. Utóbbiaknál a lelőhelyen kívül az egyes gyűjtési időpontokat, az egyedek számát (hím és nőstény), valamint a gyüjtö(k) nevének rövidítését közöljük, az alábbiak szerint:

\section{Gyüjtők és cikkek szerzőinek rövidítése:}

$\begin{array}{llll}\text { Á } & \text { Ábrahám Levente } & \text { O } & \text { Oláh János } \\ \text { GT } & \text { Gergely Tibor } & \text { Ö } & \text { Ötvös Károly } \\ \text { GÁ } & \text { Gáborik Ákos } & \text { Sz } & \text { Szivák Ildikó } \\ \text { Ma } & \text { Malicky, Hans } & \text { U } & \text { Uherkovich Ákos } \\ \text { M } & \text { Molnár Dániel } & \text { UP } & \text { Uherkovich Péter } \\ \text { Mo } & \text { Móra Arnold } & \text { USz } & \text { Uherkovich Szaniszló }\end{array}$

N Nógrádi Sára

\section{Rhyacophilidae}

Rhyacophila dorsalis (Curtis, 1834) - Bélavár, Dráva (N \& U 1998); Drávasztára (N \& U 1995); Muraszemenye (U 2004); Örtilos, Dráva (N \& U 1995, 1998); Rédics, Kebele-p. (U 2004); Vejti, Dráva (N \& U 1995); Vízvár, Dráva (N \& U 1998) - Bélavár, Dráva 2002. VI. 18. 1 đ̊ (N, U), 2002. X. 17.3 đ 1 \& (N,

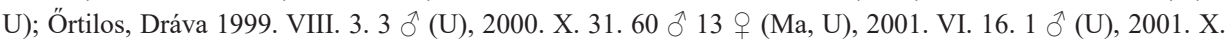

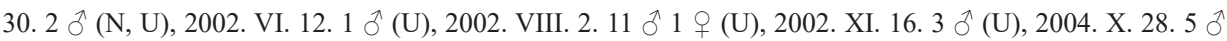

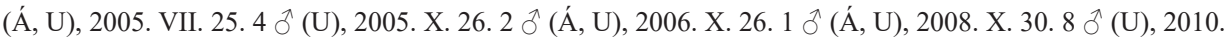

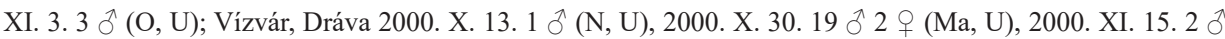

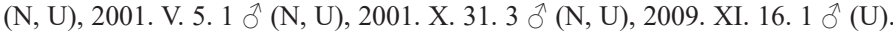

Rhyacophila fasciata Hagen, 1859 - Abaliget, Nyáras-v. (U \& N 2006); Bükkösd, Gorica (N et al. 1985); Bükkösd, Korpád, Sormás-v. (N et al. 1985); Hetvehely, Bükkösdi-v. (N \& U 1990, U \& N 2006); Hetvehely, Káni-p. (N \& U 1990); Hetvehely, Nyáras-v. (N et al. 1985, U \& N 2006); Magyarszombatfa (U \& N 1992a);

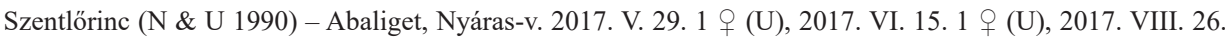

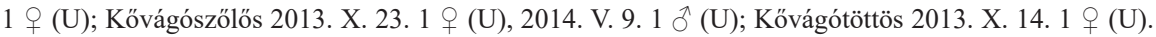
Rhyacophila hirticornis McLachlan, 1879 - Pécs, Éger-völgy (N et al. 1985, U \& N 2006) - Pécs, Éger-v. 2013. V. 10.9 万人 6 ㅇ (U).

Rhyacophila pascoei McLachlan, 1879 - Magyarszombatfa (U \& N 1992a).

\section{Glossosomatidae}

Glossosoma boltoni Curtis, 1834 - Magyarszombatfa (U \& N 1992a); Örtilos, Dráva (N \& U 1995) -

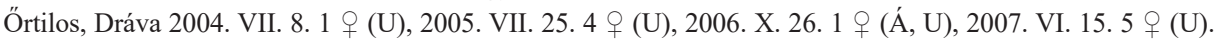
Glossosoma conformis Neboiss, 1963 - Magyarszombatfa (U \& N 1992a).

Agapetus delicatulus McLachlan, 1884 - Barcs, halastó (N 1985a, 1986); Magyarszombatfa (U \& N 1992a).

Agapetus laniger (Pictet, 1834) - Barcs, halastó (N 1985a); Dobri (U 2004); Kercaszomor (U 2004); Kerkaszentkirály, Kerka (U 2004); Magyarszombatfa (U \& N 1992a); Örtilos, Dráva (N \& U 1995) -

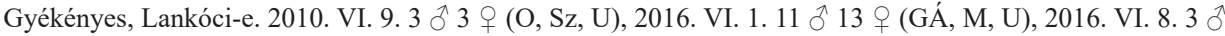

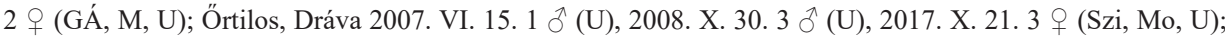
Vízvár, Dráva 2007. VI. 3.1 đ (U), 2009. XI. 16. 1 đ̊ (U), 2015. IX. 16. 2 đ 1 q (GÁ, M, U), 2016. V. 28. 40 ô 25 우 (GÁ, U).

Agapetus ochripes Curtis, 1834 - Örtilos, Dráva 2008. X. 30.1 đิ (U).

Synagapetus mosely (Ulmer, 1938) - Abaliget, Nyáras-v. (U \& N 2006); Bakonya, Sás-v. (U \& N 2006); Hetvehely, Nyáras-v. (U \& N 2006); Pécs, Éger-völgy (N et al. 1985, U \& N 2006) - Abaliget, Nyáras-v. 2017.

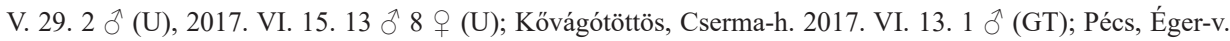
2013. V. 10. 1 đิ 2 ๆ (U); Pécs, Mecsekszentkút, Szunyola 2014. VI. 22.1 đ (GT, U). 


\section{Hydroptilidae}

Orthotrichia angustella (McLachlan, 1865) - Drávaszabolcs, Holt-Fekete-víz (N \& U 1998); Drávasztára (N \& U 1995); Kisdobsza (N 1986, N \& U 1988); Komlósd (N \& U 1998); Rédics, Kebele-p. (U 2004); Vejti, Dráva (N \& U 1995); Vízvár, Dráva-p. (N \& U 1995) - Bélavár, Lókai-mező 2002. VI. 20. 1 \& (U); Gyékényes, Lankóci-e. 2016. VI. 8. 1 † (GÁ, M, U); Örtilos, Dráva 2001. VI. 16. 1 \& (U); Vízvár, Dráva 2003. V. 30. 1 § 1 ㅇ (N, U).

Orthotrichia costalis (Curtis, 1834) - Abaliget, Nyáras-v. (U \& N 2006); Babócsa, Rinya (N \& U 1998); Barcs, halastó (N 1985a, N \& U 1995); Barcs, halastó I. (N \& U 1998); Barcs, Kisbók (N \& U 1998); Barcs, Rinya-Ó-Dráva (N \& U 1998); Bélavár, Lókai-mező (N \& U 1998); Bükkösd, Szentdomján (U \& N 2006); Csertő (N \& U 1990); Darány, Nagyberek (N \& U 1998); Drávapalkonya (N \& U 1995, 1998); Drávasztára (N \& U 1998); Felsőszentmárton, Mrtvica (N \& U 1998); Gordisa, Mattyi-tó (N \& U 1995); Gyékényes, kavicsbányató (N \& U 1995); Heresznye (N \& U 1998); Kerkaszentkirály, Kerka (U 2004); Kisdobsza (N \& U 1988); Komlósd (N \& U 1998); Magyarföld (U 2004); Magyarszombatfa (U \& N 1992a); Örtilos, Dráva (N \& U 1995); Patosfa (N \& U 1990); Pellérd, halastavak (U \& N 2006); Somogyudvarhely, Dombó-csat. (N \& U 1998); Szentborbás (U \& N 1992b); Vejti, Dráva (N \& U 1995); Zalabaksa (U 2004) - Bakonya, Nagy-Rege 2017. VI. 12. 1 † (U); Barcs, Kis-bók 1999. VIII. 5. 60 § 66 o (U); Bélavár, Lókai-mező 2002. VI. 20. 1 †

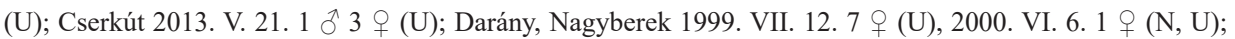
Drávapalkonya 1999. VI. 28. 1 † (U); Drávasztára 1999. VI. 12. 1 đ (N, U), 1999. VIII. 9. 1 q (U); Felsőszentmárton, Mrtvica 1999. VI. 20. 1 đ 20 q (U); Gordisa, Mattyi-tó 1999. VII. 5. 6 q (N, U); Gyékényes, Lankóci-e. 2006. VI. 14. 1 \& (U), 2010. VI. 9. 1 \& (O, Sz, U), 2011. V. 19. 1 † (O, U); Pécs, Mecsekszentkút, Szunyola 2014. VI. 29. 2 † (U); Somogyudvarhely 1999. VIII. 4. 6 đ 18 q (U); Vízvár, Dráva 2001. VII. 14. 1 q (U, UP), 2001. VIII. 4.1 đ(N, U), 2002. VI. 9.2 q (U), 2002. VIII. 26.1 q (N, U), 2003. V. 30. 1 § 1 \& (N, U), 2016. V. 28. 1 \& (GÁ, U).

Orthotrichia tragetti Mosely, 1930 - Almamellék, Sas-rét (N \& U 1990); Babócsa, Rinya (N \& U 1998); Barcs, halastó (N 1985a, 1985b, N \& U 1995); Barcs, halastó I. (N \& U 1998); Barcs, Kisbók (N \& U 1998); Bélavár, Dráva (N \& U 1998); Bélavár, Lókai-mező (N \& U 1998); Csertő (N \& U 1990); CsesztregKerkaújfalu (U 2004); Darány, Nagyberek (N \& U 1995, 1998); Diósviszló (N 2000); Drávapalkonya (N \& U 1995); Drávasztára (N \& U 1995); Drávaszabolcs, Holt-Fekete-víz (N \& U 1998); Drávasztára (N \& U 1998); Felsőszentmárton, Mrtvica (N \& U 1998); Gordisa, Mattyi-tó (N \& U 1995); Gyékényes, kavicsbányató (N \& U 1995); Heresznye (N \& U 1998); Kemse, Háromfa (N \& U 1995); Kerkaszentkirály, Kerka (U 2004); Kisdobsza (N 1986, N \& U 1988); Kisszentmárton, Majláthpuszta (N \& U 1995); Komlósd (N \& U 1998); Magyarföld (U 2004); Magyarszombatfa (U \& N 1992a); Örtilos, Dráva (N \& U 1995, 1998); Patosfa (N \& U 1990); Rédics, Kebele-p. (U 2004); Somogyudvarhely, Dombó-csat. (N \& U 1998); Szaporca, Kisinci (N \& U 1998); Szentborbás (U \& N 1992b, N \& U 1998); Tótszerdahely (U 2004); Vejti, Dráva (N \& U 1995, 1998); Vízvár, Dráva (N \& U 1995, 1998); Zalabaksa (U 2004) - Almamellék, Almás-p. 1998. VII. 19. 6 q (U); Barcs, Kis-bók 1999. VIII. 5. 145 đ 1020 q (U); Bélavár, Dráva 2002. VI. 18. 8 đ33 o (N, U), 2003. VI. 12.

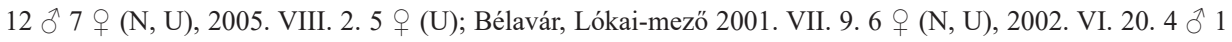
ㅇ (U); Darány, Nagyberek 1998. IX. 25. 1 ㅇ (N, U), 1999. VII. 12. 1 đ (U), 2000. VI. 6. 1 ㅇ (N, U); Drávapalkonya 1999. VI. 28. 1 đ 5 (U); Drávasztára 1999. VI. 12. 1 q (N, U); Felsőszentmárton, Mrtvica 1999. VI. 20. 1 đ 62 † (U); Gordisa, Mattyi-tó 1999. VII. 5. 11 q (N, U); Gyékényes, Lankóci-e. 2000. V. 28.

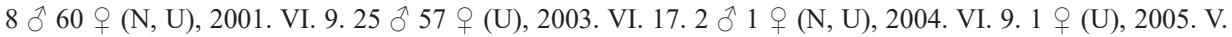

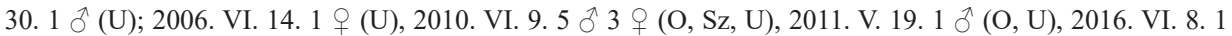

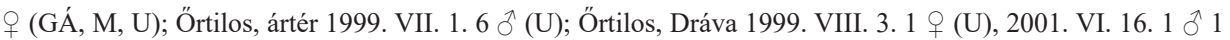
q (U), 2002. VI. 12. 1 ð(U), 2002. VIII. 2. 2 (U), 2003. VI. 26. 1 (U), 2004. VII. 8.1 q (U), 2005. VII. 25. 2 ^ 2 (U); Somogyudvarhely 1999. VIII. 4. 2 đ 18 (U); Vízvár, Dráva 2000. V. 25. 2 q (N, U), 2001.

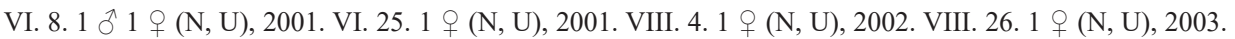

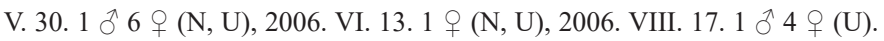

Ithytrichia lamellaris Eaton, 1873 - Barcs, halastó (N 1985a); Kerkaszentkirály, Kerka (U 2004); Kisdobsza (N \& U 1988); Magyarföld (U 2004); Magyarszombatfa (U \& N 1992a); Örtilos, Dráva (N \& U 1995); Szentborbás (U \& N 1992b); Zalabaksa (U 2004). 
Oxyethira falcata Morton, 1893 - Alsószenterzsébet (U 2004); Babócsa, Rinya (N \& U 1998); Barcs, halastó (N 1985a, N \& U 1995); Bükkösd, Bükkösdi-v. (U \& N 2006); Csertő (N \& U 1990); Csesztreg-Kerkaújfalu (U 2004); Diósviszló (N 2000); Homokszentgyörgy (N \& U 1988); Kercaszomor (U 2004); Kerkaszentkirály, Kerka (U 2004); Kisdobsza (N \& U 1988); Magyarföld (U 2004); Magyarszombatfa (U \& N 1992a); Örtilos, Dráva (N \& U 1995); Rédics, Kebele-p. (U 2004); Tótszerdahely (U 2004); Vejti, Dráva (N \& U 1998); Zalabaksa (U 2004) - Pécs, Mecsekszentkút, Szunyola 2014. VI. 29. 1 ठ̊ (U).

Oxyethira flavicornis (Pictet, 1834) - Babócsa, ártér (N \& U 1998); Barcs, halastó (N 1985a, 1985b); Barcs, halastó I. (N \& U 1998); Barcs, Rinya-Ó-Dráva (N \& U 1998); Bélavár, Dráva (N \& U 1998); Bélavár, Lókaimező (N \& U 1998); Belezna, Mura (N \& U 1998); Dobri (U 2004); Drávasztára (N \& U 1998); Gyékényes, kavicsbányató (N \& U 1995); Kerkaszentkirály, Kerka (U 2004); Magyarföld (U 2004); Örtilos, Dráva (N \& U 1995); Örtilos, ártér (N \& U 1998); Somogyudvarhely, Dombó-csat. (N \& U 1998); Tótszerdahely (U 2004); Vízvár, Dráva (N \& U 1998) - Bélavár, Dráva 2002. VI. 18. 2 \& (N, U), 2002. X. 17. 1 q (N, U); Bélavár,

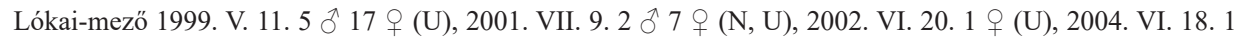
o 4 \& (U); Darány, Nagyberek 1998. IX. 25. 1 † (N, U); Felsőszentmárton, Mrtvica 1999. VI. 20. 1 q (U);

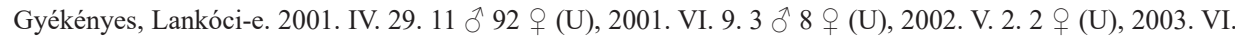

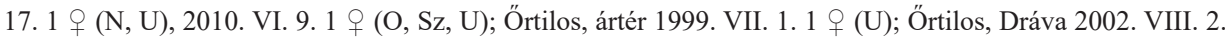
1 đ (U); Somogyudvarhely 1999. VIII. 4. 1 đิ 11 \& (U); Vízvár, Dráva 2000. IV. 28.1 \& (N, U), 2001. V. 5.

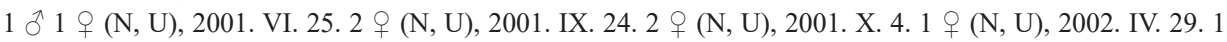

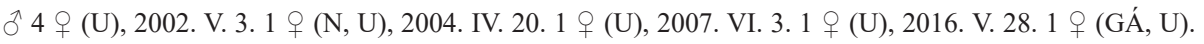

Oxyethira tristella Klapálek, 1895 - Pécs, Mecsekszentkút, Szunyola 2014. VII. 19. 1 ठ̊ (U).

Hydroptila angustata Mosely, 1939 - Alsószenterzsébet (U 2004); Örtilos, Dráva (N \& U 1995); Szentborbás (U \& N 1992b) - Bélavár, Dráva 2002. VI. 18. 7 q (N, U), 2003. VI. 12.1 q (N, U), Örtilos, Dráva 1999. VIII. 3.2 (U), 2002. VIII. 2. 6 11 (U), 2003. VI. 26.3 12 9 (U); Pécs, Mecsekszentkút, Szunyola 2014. VI. 29. 3 ภ 2 q (U); Vízvár, Dráva 2001. V. 5.1 đ (N, U), 2002. V. 3.1 đ (N, U), 2002. VI. 9.1 ô (U), 2002. VI.

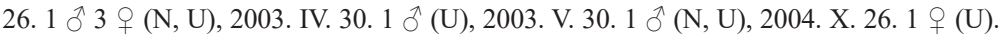

Hydroptila dampfi Ulmer, 1929 - Almamellék, Sas-rét (N \& U 1990); Gyékényes, kavicsbányató (N \& U 1995).

Hydroptila forcipata (Eaton, 1873) - Alsószenterzsébet (U 2004); Bélavár, Dráva (N \& U 1998); Bélavár, Lókai-mező (N \& U 1998); Csesztreg-Kerkaújfalu (U 2004); Dobri (U 2004); Kercaszomor (U 2004); Kerkaszentkirály, Kerka (U 2004); Kisdobsza (N 1986, N \& U 1988); Magyarföld (U 2004); Örtilos, Dráva (N \& U 1995); Rédics, Kebele-p. (U 2004); Tótszerdahely (U 2004); Vejti, Dráva (N \& U 1995) - Bélavár, Dráva 2003. V. 2.1 ô 1 q (U); Bélavár, Lókai-mező 2004. VI. 18. 1 \& (U); Gyékényes, Lankóci-e. 2001. VI.

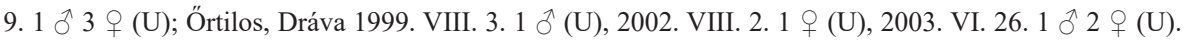

Hydroptila lotensis Mosely, 1930 - Alsószenterzsébet (U 2004); Csesztreg-Kerkaújfalu (U 2004); Kerkaszentkirály, Kerka (U 2004); Kisdobsza (N \& U 1988); Magyarföld (U 2004); Magyarszombatfa (U \& N 1992a); Örtilos, Dráva (N \& U 1995); Vejti, Dráva (N \& U 1995); Zalabaksa (U 2004) - Gyékényes, Lankóci-e. 2004. VI. 9. 1 ठิ (U); Örtilos, Dráva 2005. VII. 25. 1 † (U), 2007. VI. 15. 2 đ 5 q (U); Pécs, Mecsekszentkút, Szunyola 2014. VII. 20. 1 q (U); Vízvár, Dráva 2000. X. 13.1 \& (N, U), 2004. V. 20. 3 ๙ (U), 2007. VII. 2. $2 \AA 4$ (U).

Hydroptila occulta (Eaton, 1873) - Barcs, halastó (N 1985a); Magyarszombatfa (U \& N 1992a).

Hydroptila pulchricornis Pictet, 1834 - Barcs, halastó I. (N \& U 1998).

Hydroptila sparsa Curtis, 1834 - Alsószenterzsébet (U 2004); Babócsa, Rinya (N \& U 1998); Barcs, halastó (N 1985a); Barcs, halastó I. (N \& U 1998); Barcs, Rinya-Ó-Dráva (N \& U 1998); Bélavár, Dráva (N \& U 1998); Bélavár, Lókai-mezö (N \& U 1998); Belezna, Mura (N \& U 1998); Berzence, Dombó-csat. (N \& U 1998); Bükkösd, Bükkösdi-v. (U \& N 2006); Bükkösd, Szentdomján (U \& N 2006); Csesztreg-Kerkaújfalu (U 2004); Diósviszló (N 2000); Dobri (U 2004); Drávapalkonya (N \& U 1995, 1998); Drávaszabolcs, HoltFekete-víz (N \& U 1998); Drávasztára (N \& U 1995, 1998); Drávatamási (N \& U 1998); Gordisa, Mattyi-tó (N \& U 1995); Gyékényes, kavicsbányató (N \& U 1995); Heresznye (N \& U 1998); Hetvehely, Bükkösdi-v. (U \& N 2006); Kemse, Háromfa (N \& U 1995); Kercaszomor (U 2004); Kerkaszentkirály, Kerka (U 2004); Kisdobsza (N \& U 1988); Komlósd (N \& U 1998); Magyarföld (U 2004); Magyarszombatfa (U \& N 1992a); 


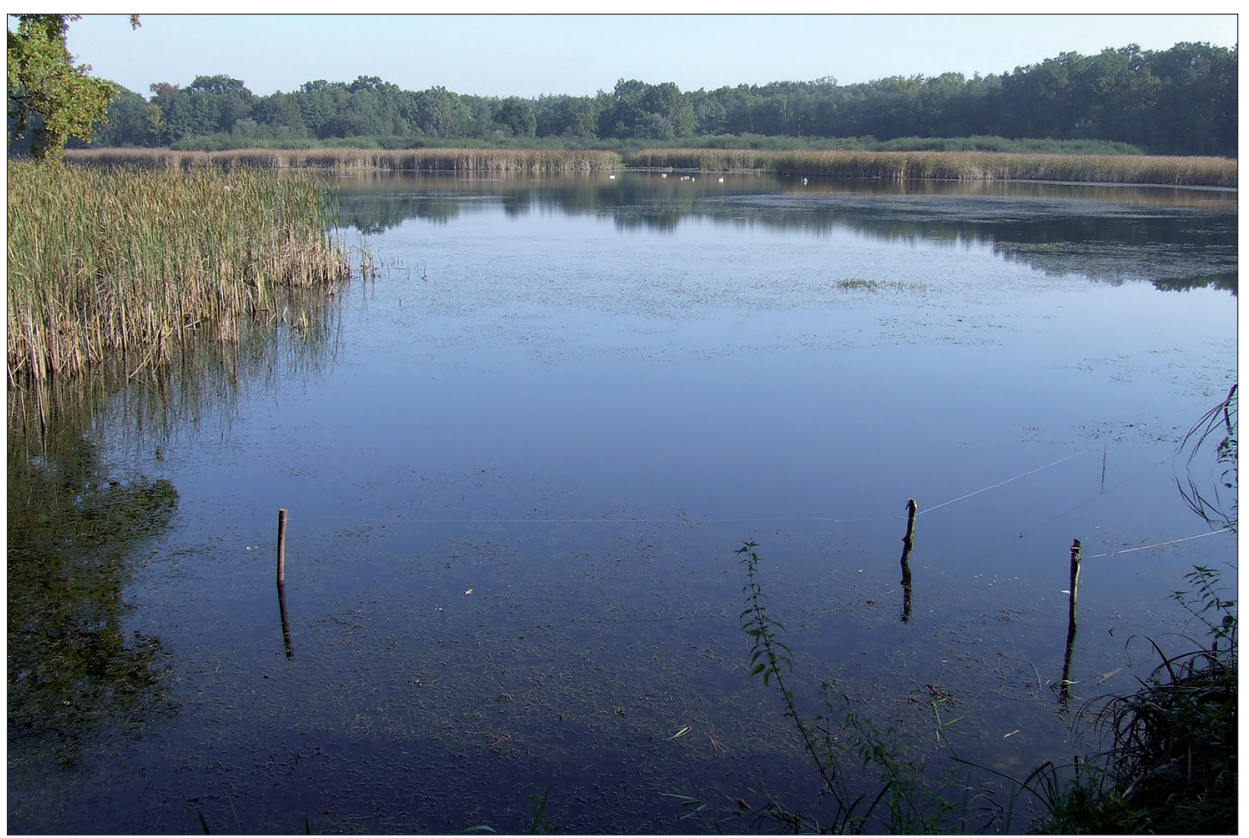

1. ábra: A IX. halastó Középrigócnál (Bares)

Fig. 1: Fish pond No 9 at Középrigóc (Barcs)

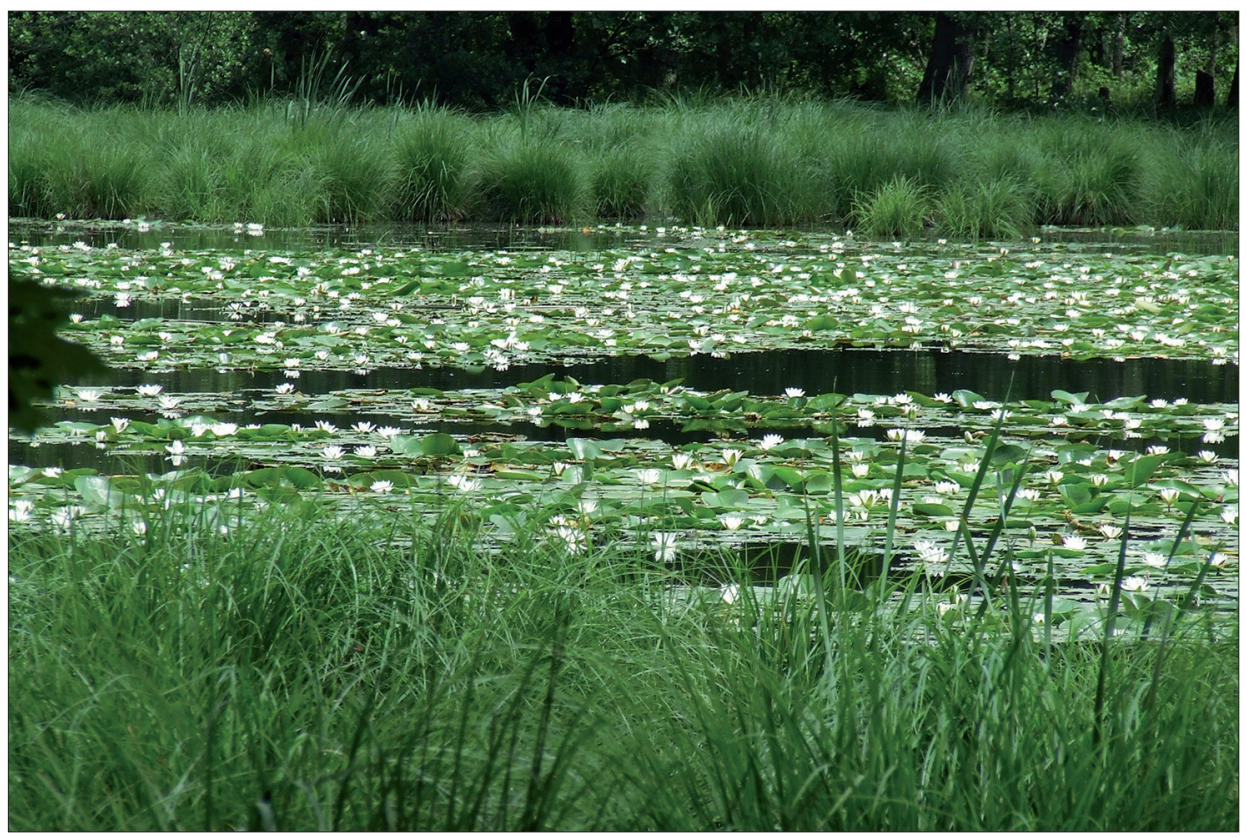

2. ábra: A darányi Nagy-berek Tündérrózsás-tava magas vízállásnál, gazdag tündérrózsa állománnyal

Fig. 2: The Tündérrózsás-tó of Nagy-berek at Darány, high water level, with abundant water lily stand 


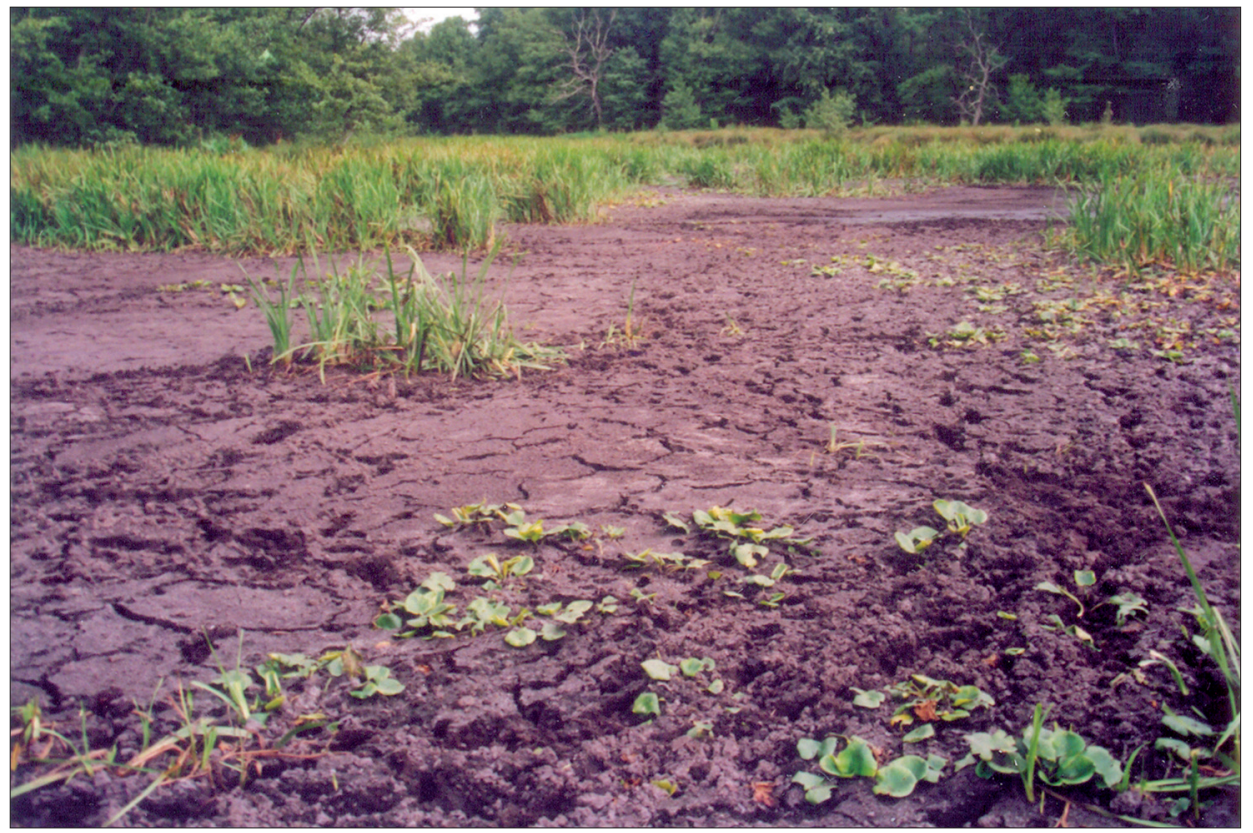

3. ábra: Ugyanaz egy hosszabb száraz időszak után: csak az iszapos mederágy látszik

Fig. 3: Same site after a long dry period: only the muddy bed seems

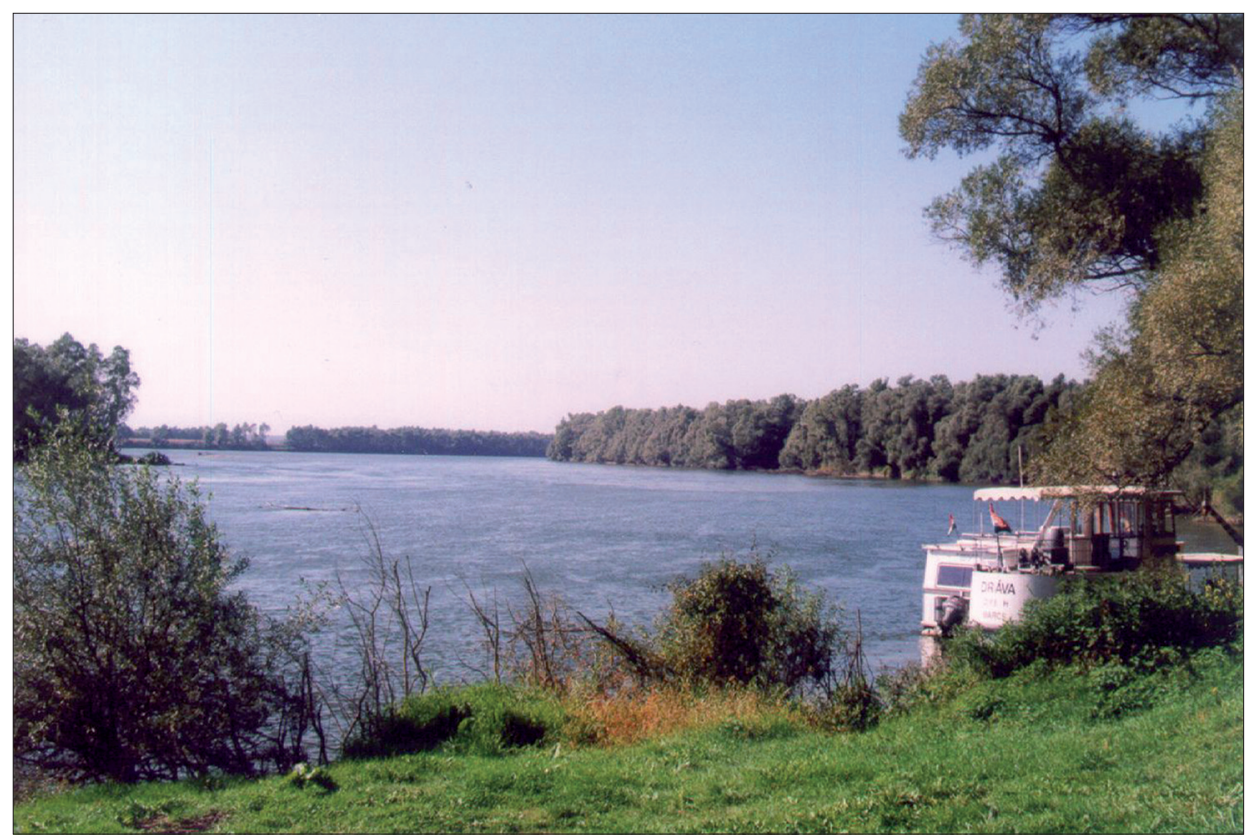

4. ábra: A Dráva Drávasztáránál, magas vízállás mellett

Fig. 4: Drava river with high water level at Drávasztára 
Örtilos, Dráva (N \& U 1995); Örtilos, Új-Zrínyi-vár (N \& U 1998); Rédics, Kebele-p. (U 2004); Somogyudvarhely, Dombó-csat. (N \& U 1998); Szava (N 2000); Szentborbás (N \& U 1998); Tótszerdahely (U 2004); Tótújfalu, Dráva (N \& U 1998); Vejti, Dráva (N \& U 1995, 1998); Vízvár, Dráva (N \& U 1995, 1998); Zalabaksa (U 2004) - Almamellék, Almás-p. 1998. VII. 19. 1 đิ 1 \& (U); Bakonya, Nagy-Rege 2017.

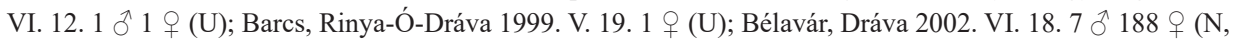

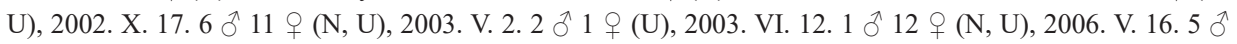
18 q (U); Bélavár, Lókai-mezö 2001. VII. 9.4 \& (N, U), 2002. VI. 20. 1 đ 1 q (U), 2004. VI. 18.1 \& (U);

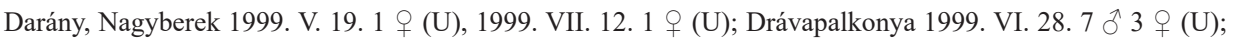

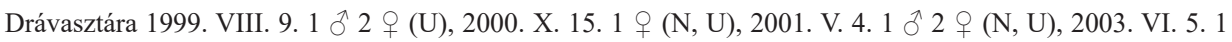
q (U), 2004. VIII. 18. 3 q (U), 2006. V. 23. 2 đ 24 † (U); Gordisa, Mattyi-tó 1999. VII. 5.1 đ (N, U); Gyékényes, Lankóci-e. 2000. V. 28. 4 q (N, U), 2003. VI. 17. 2 q (N, U), 2004. VI. 9.1 q (U), 2005. V. 30.

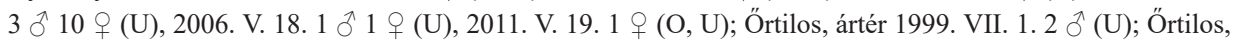
Dráva 1999. VI. 30.436 \& (U), 1999. VIII. 3.3 o 14 (U), 2001. VI. 16.1 q (U), 2002. VI. 12.3 6 \%

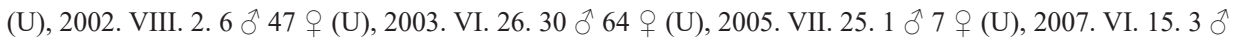

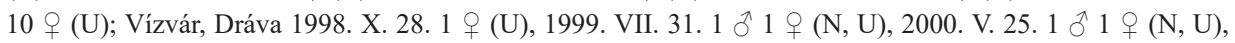

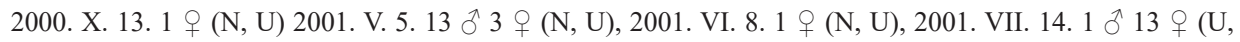
UP), 2001. VIII. 4.5 q (N, U), 2001. IX. 24. 36 क 53 क (N, U), 2001. X. 4.112 o 37 ㅇ (N, U), 2002. IV. 29.

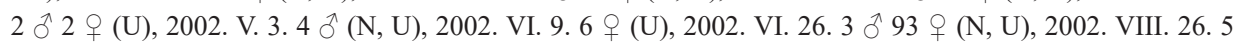

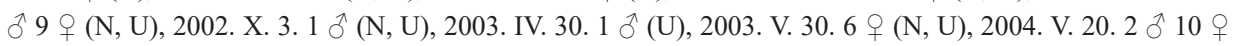

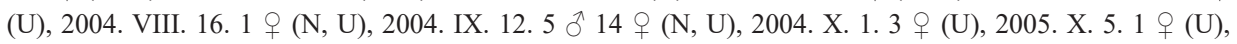

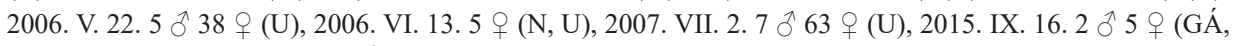
M, U), 2016. V. 28. 1 ô 1 † (GÁ, U).

Hydroptila tineoides Dalman, 1819 - Kisdobsza (N \& U 1988); Magyarszombatfa (N 1985b, U \& N 1992a).

Hydroptila vectis Curtis, 1834 - Örtilos, Dráva (N \& U 1995) - Bélavár, Lókai-mező 2002. VI. 20. 2 q (U);

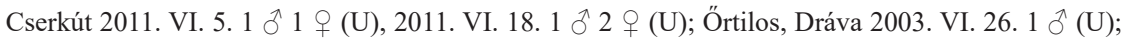

Agraylea sexmaculata Curtis, 1834 - Barcs, halastó (N 1985a, N \& U 1995); Barcs, halastó I. (N \& U 1998); Barcs, Rinya-Ó-Dráva (N \& U 1998); Bélavár, Dráva (N \& U 1998); Bélavár, Lókai-mező (N \& U 1998); Bükkösd, Bükkösdi-v. (U \& N 2006); Csertő (N \& U 1990); Drávapalkonya (N \& U 1998); Drávasztára (N \& U 1995, 1998); Gordisa, Mattyi-tó (N \& U 1995); Gyékényes, kavicsbányató (N \& U 1995); Kerkaszentkirály, Kerka (U 2004); Magyarszombatfa (U \& N 1992a); Patosfa (N \& U 1990); Örtilos, Dráva (N \& U 1995); Rédics, Kebele-p. (U 2004); Somogyapáti (N \& U 1990); Szava (N 2000); Szentborbás (U \& N 1992b, N \& U 1998); Szentlőrinc (N \& U 1990); Tótújfalu, Dráva (N \& U 1998); Vejti, Dráva (N \& U 1995) - Almamellék, Almás-p. 1998. VII. 19. 19 ô 7 q (U); Barcs, Kis-bók 1999. VIII. 5. 1 o 3 q (U); Bélavár, Dráva 2002. VI.

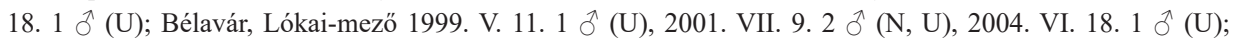
Darány, Nagyberek 1999. VII. 12. 1 đ(U), 2000. VI. 6.3 đ 1 \& (N, U); Felsőszentmárton, Mrtvica 1999. VI.

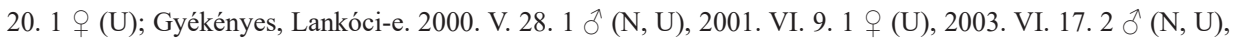
2004. VI. 9.1 (U); Örtilos, ártér 1999. VII. 1.2 đ (U); Vízvár, Dráva 2001. V. 5.1 ô 1 † (N, U), 2001. VI.

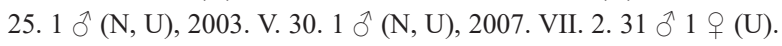

Allotrichia pallicornis (Eaton, 1873) - Magyarszombatfa (U \& N 1992a).

\section{Philopotamidae}

Wormaldia occipitalis (Pictet, 1834) - Pécs, Éger-völgy (N et al. 1985).

\section{Hydropsychidae}

Hydropsyche angustipennis (Curtis, 1834) - Almamellék, Sas-rét (N \& U 1990); Almamellék, Szentmártonpuszta (N \& U 1990); Alsószenterzsébet (U 2004); Babarcszőlős (N 2000); Babócsa, Rinya (N \& U 1995, 1998); Barcs, halastó I. (N \& U 1998); Barcs, Barcs-Komlósdi-Rinya (N \& U 1998); Bélavár, Almásberek (N \& U 1998); Bélavár, Lókai-mező (N \& U 1998); Belezna, Kakonyapuszta (N \& U 1998); Berzence, Dombó-csat. (N \& U 1998); Berzence, Tekeres-berki-p. (N \& U 1998); Böhönye (N \& U 1992); Csertő (N \& 
U 1990); Csesztreg-Kerkaújfalu (U 2004); Drávaszentes, Komlósdi-Rinya (N \& U 1998); Drávasztára (N \& U 1998); Hedrehely (N et al. 1985); Hegyszentmárton (N 2000); Heresznye (N \& U 1998); Kerkaszentkirály, Kerka (U 2004); Kerkaszentmihály-Margitmajor, Lendva (U 2004); Kisdobsza (N \& U 1988); Kisharsány (N 2000); Komlósd (N \& U 1998); Magyarszombatfa (U \& N 1992a); Nagydobsza (N \& U 1988); Örtilos, Dráva (N \& U 1995); Örtilos, Új-Zrínyi-vár (N \& U 1998); Patosfa (N \& U 1990); Resznek, Szentgyörgyvölgyi-p. (U 2004); Somogyapáti (N \& U 1990); Somogyhatvan (N \& U 1990); Somogyudvarhely, Dombó-csat. (N \& U 1998); Szava (N 2000); Szécsisziget, Petrócpuszta, Cserta (U 2004); Szentlőrinc (N \& U 1990); Szulimán (N \& U 1990); Vejti, Dráva (N \& U 1995); Vízvár, Dráva (N \& U 1995) - Babócsa, Rinya 1999. V. 19.1 đ (U); Bélavár, Almás-berek 2000. V. 4.18 đ (U), 2002. IV. 16.5 đ (U); Bélavár, Dráva 2003. V. 2.1 đ(U); Berzence, Dombó-csatorna 2000. V. 4.5 đิ (U); Darány, Nagyberek 2000. VI. 6. 1 đ (N, U); Drávapalkonya 1999. V. 2.1 ô (U); Drávasztára 2003. VI. 5.1 đ (U); Gyékényes, Lankóci-e. 2000. V. 28.1 đ (N, U), 2004.

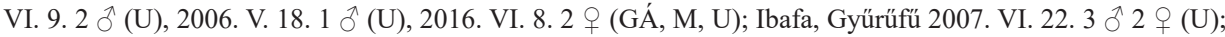
Kisdobsza 2005. IV. 29. 8 1 क (U); Komlósd 2005. V. 3.1 đ (U); Örtilos, Dráva 1999. VIII. 3.1 (U), 2002. VI. 12. 1 (U), 2004. VII. 8. 1 (U), 2007. VI. 15. 2 (U); Pécs, Nagypostavölgy 2017. VII. 10-18.

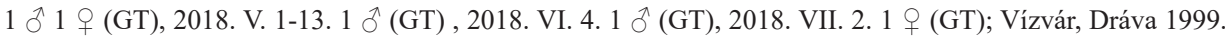

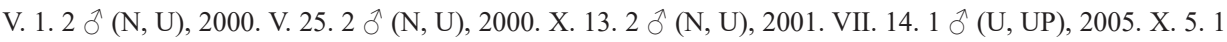
§ (U), 2016. V. 28.1 § 2 \& (GÁ, U).

Hydropsyche bulbifera McLachlan, 1878 - Alsószenterzsébet (U 2004); Böhönye (N \& U 1992); Kercaszomor (U 2004); Kisdobsza (N et al. 1985); Magyarföld (U 2004); Magyarszombatfa (U \& N 1992a); Örtilos, Dráva (N \& U 1995); Somogyudvarhely, Dombó-csat. (N \& U 1998); Szentlőrinc (N \& U 1990); Vízvár, Dráva (N \& U 1995); Vízvár, község (N \& U 1995) - Bélavár, Lókai-mező 2004. VI. 18.1 ô (U);

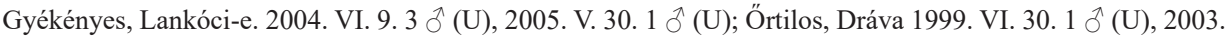

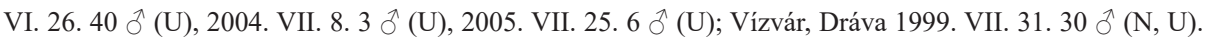

Hydropsyche bulgaromanorum Malicky, 1977 - Almamellék, Sas-rét (N \& U 1990); Babócsa, ártér (N \& U 1998); Babócsa, Rinya (N \& U 1998); Barcs, Csikota (N 1985a); Barcs, Dráva-part (N \& U 1995, 1998); Barcs, erdészet (N 1985a); Barcs, erdészház (N 1985a); Barcs, halastó (N 1985a, N \& U 1995); Barcs, Kisbók (N \& U 1998); Barcs, szakiskola (N \& U 1998); Bélavár, Dráva (N \& U 1998); Bélavár, Kerék-hegy (N \& U 1998); Bélavár, Lókai-mező (N \& U 1998); Belezna, Mura (N \& U 1998); Böhönye (N \& U 1992); Csarnóta (N 2000); Cserkút (N et al. 1985); Csertő (N \& U 1990); „Darány“ (UJHELYI 1981a); Darány, Kuti őrház (N 1985a, N \& U 1998); Darány, Nagyberek (N \& U 1995); Diósviszló (N 2000); Drávapalkonya (N \& U 1995, 1998); Drávaszabolcs, Holt-Fekete-víz (N \& U 1998); Drávaszentes, Ferenctelep (N \& U 1998); Drávasztára (N \& U 1995, 1998); Drávatamási (N \& U 1995, 1998); Felsőszentmárton, Korcsina-csat. (N \& U 1998); Felsőszentmárton, Mrtvica (N \& U 1998); Gordisa, Mattyi-tó (N \& U 1995); Gyékényes, kavicsbányató (N \& U 1995); Heresznye (N \& U 1998); Homokszentgyörgy (N \& U 1988); Kemse, Háromfa (N \& U 1995); Kercaszomor (U 2004); Kisdobsza (N \& U 1988); Kisharsány (N 2000); Kisszentmárton, Dráva (N \& U 1998); Kisszentmárton, Majláthpuszta (N \& U 1995); Magyarszombatfa (U \& N 1992a); Matty, Keselyősfapuszta (N \& U 1995); Örtilos, ártér (N \& U 1998); Örtilos, Dráva (N \& U 1995); Patosfa (N \& U 1990); Pécs, Deindol (U \& N 2006); Pellérd, halastavak (U \& N 2006); Péterhida (N \& U 1998); Potony (N \& U 1998); Siklós, Csukma-h. (N 2000); Siklós, Göntér (N 2000); Siklós-Máriagyüd (N 2000); Somogyapáti (N \& U 1990); Somogyudvarhely, Dombó-csat. (N \& U 1998); Szaporca, Kisinci (N \& U 1998); Szentborbás (U \& N 1992b, N \& U 1998); Szulimán (N \& U 1990); Tótszerdahely (U 2004); Tótújfalu, Dráva (N \& U 1998); Vejti, Dráva (N \& U 1995, 1998); Vízvár, Dráva (N \& U 1995, 1998); Zákány (N \& U 1998); Zaláta, Lajos-tanya (N \& U

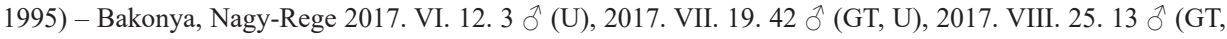
U); Barcs, Kis-bók 1999. VIII. 5. 11 đิ (U); Barcs, Szilonics-p. 1999. V. 19. 1 đૈ (U); Bélavár, Dráva 2002. VI.

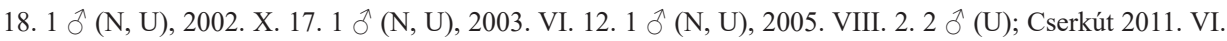

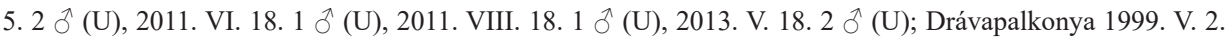

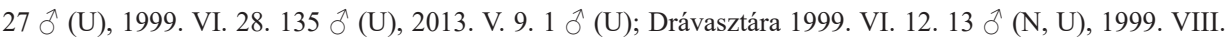

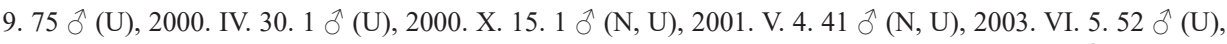

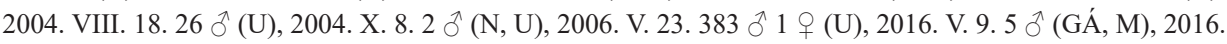

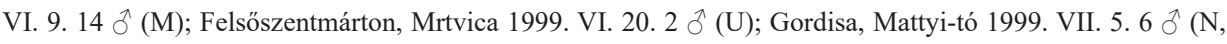




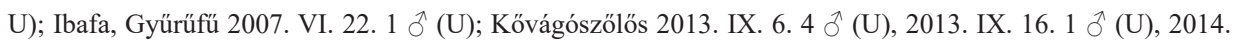
VI. 28.2 (GT, U); Kövágószőlős, Jakab-h. 2016. VII. 31. 1 (GT, U), 2017. VI. 27. 2 § (GT); Kővágótöttös,

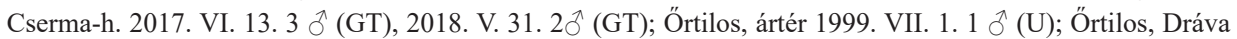

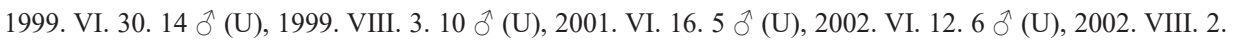

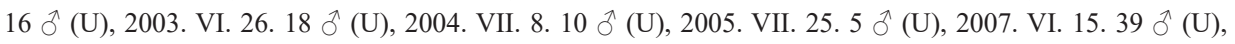

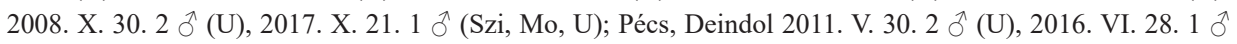

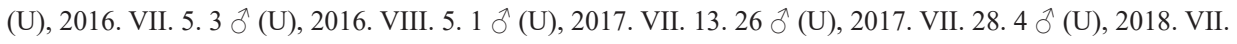
5. 13 ठ (U), 2018. VIII. 13. 1 đ (U); Pécs, Mecsekszentkút, Szunyola 2014. VI. 29. 2 đ (U); Pécs, Nagyárpád,

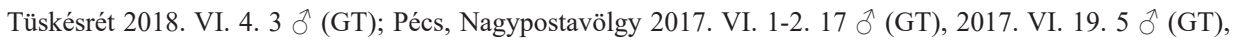

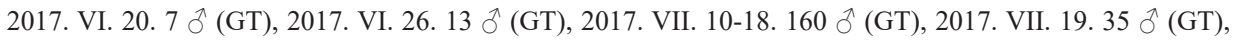

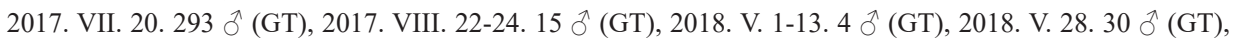

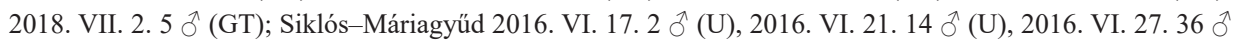

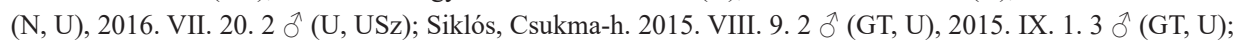
Somogyudvarhely 1999. VIII. 4. 1 đิ (U); Vízvár, Dráva 1999. VII. 31. 4 o (N, U), 1999. IX. 30.2 ô(U),

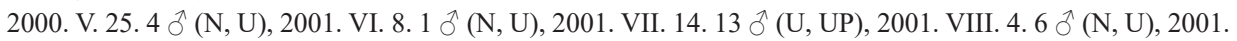

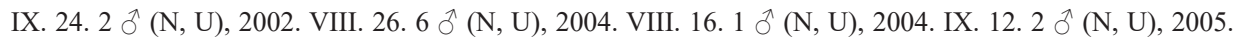

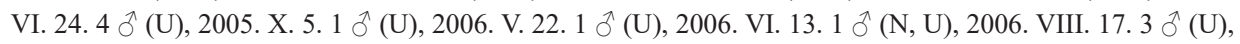

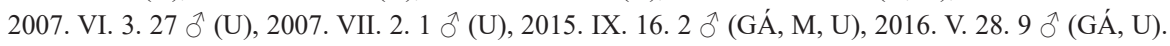

Hydropsyche contubernalis McLachlan, 1865 - Abaliget, Nyáras-v. (N et al. 1985); Almamellék, Sas-rét (N \& U 1990); Alsószenterzsébet (U 2004); Babócsa, ártér (N \& U 1998); Babócsa, Rinya (N \& U 1998); Barcs, Csikota (N 1985a); Barcs, Dráva-part (N \& U 1995); Barcs, erdészet (N 1985a); Barcs, erdészház (N 1985a); Barcs, halastó (N 1985a, N \& U 1995); Barcs, Kisbók (N \& U 1998); Barcs, Rinya-Ó-Dráva (N \& U 1998); Barcs, szakiskola (N \& U 1998); Barcs, Szilonics-p. (N \& U 1998); Bélavár, Dráva (N \& U 1998); Bélavár, Kerék-hegy (N \& U 1998); Bélavár, Lókai-mező (N \& U 1998); Belezna, Mura (N \& U 1998); Böhönye (N \& U 1992); Bükkösd, Bükkösdi-v. (U \& N 2006); Bükkösd, Szentdomján (U \& N 2006); Csarnóta (N 2000); Cserkút (N et al. 1985); Csertő (N \& U 1990); Csesztreg-Kerkaújfalu (U 2004); Darány, Kuti őrház (N 1985a, N \& U 1998); Darány, Nagyberek (N 1985a, N \& U 1995, 1998); Diósviszló (N 2000); Dobri (U 2004); Drávapalkonya (N \& U 1995, 1998); Drávaszabolcs, Holt-Fekete-víz (N \& U 1998); Drávaszentes, Ferenctelep (N \& U 1998); Drávasztára (N \& U 1995, 1998); Drávatamási (N \& U 1998); Felsőszentmárton, Korcsina-csat. (N \& U 1998); Felsőszentmárton, Mrtvica (N \& U 1998); Gordisa, Mattyi-tó (N \& U 1995); Gyékényes, kavicsbányató (N \& U 1995); Gyékényes, Lankóci-e. (N \& U 1998); Heresznye (N \& U 1998); Hetvehely, Káni-v. (U \& N 2006); Hetvehely, Nyáras-v. (U \& N 2006); Homokszentgyörgy (N \& U 1988); Kemse, Háromfa (N \& U 1995); Kercaszomor (U 2004); Kerkaszentkirály, Kerka (U 2004); Kisdobsza (N et al. 1985; N \& U 1988); Kisharsány (N 2000); Kisszentmárton, Majláthpuszta (N \& U 1995); Komlósd (N et al. 1985, N \& U 1998); Kővágószőlős (N et al. 1985); „Középrigóc“ (UJHELYI 1981a); Magyarföld (U 2004); Magyarszombatfa (U \& N 1992a); Matty, Keselyősfapuszta (N \& U 1998); Murarátka, Holt-Mura (U 2004); Murarátka, Mura (U 2004); Muraszemenye (U 2004); Örtilos, ártér (N \& U 1998); Örtilos, Dráva (N \& U 1995, 1998); Pécs, Deindol (U \& N 2006); Pellérd, halastavak (U \& N 2006); Péterhida (N \& U 1998); Patosfa (N \& U 1990); Potony, Lugi-erdő (N \& U 1995, 1998); Rédics, Kebele-p. (U 2004); Siklós, Csukma-h. (N 2000); Siklós, Göntér (N 2000); Siklós-Máriagyüd (N 2000); Somogyapáti (N \& U 1990); Somogyudvarhely, Dombó-csat. (N \& U 1998); Szaporca, Kisinci (N \& U 1998); Szava (N 2000); Szentborbás (U \& N 1992b, 1998); Szentlőrinc (N \& U 1990); Szulimán (N \& U 1990); Tormafölde (N et al. 1985); Tótszerdahely (U 2004); Tótújfalu, Dráva (N \& U 1998); Tótújfalu, Lugi-e. (N \& U 1998); Vejti, Dráva (N \& U 1995, 1998); Vízvár, Dráva (N \& U 1995, 1998); Zákány (N \& U 1998); Zalabaksa (U 2004) - Almamellék, Almás-p. 1998.

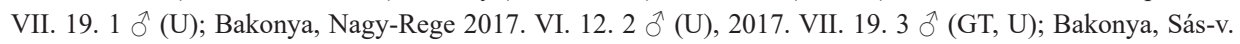

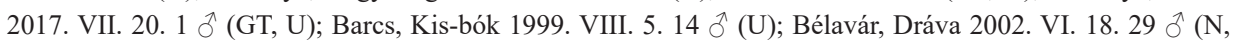

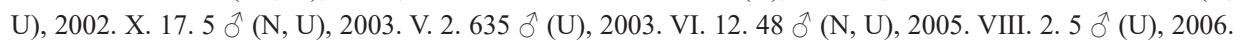

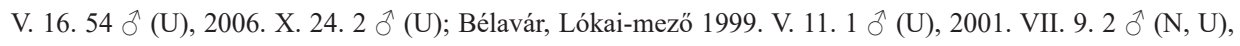

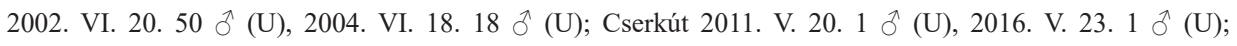

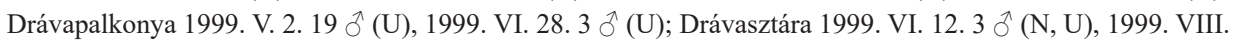




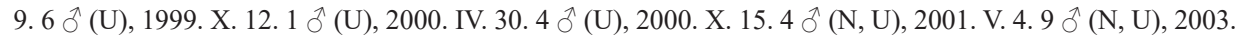

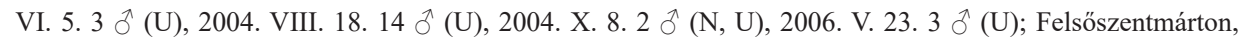

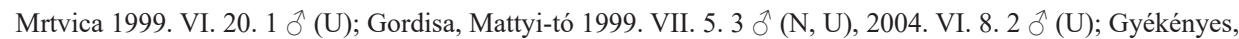

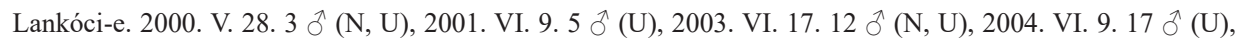

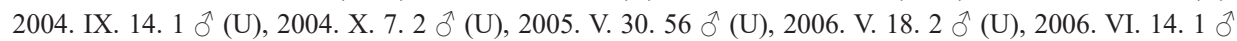

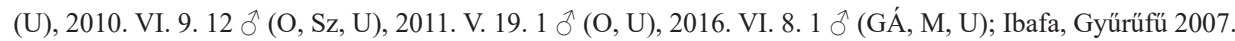

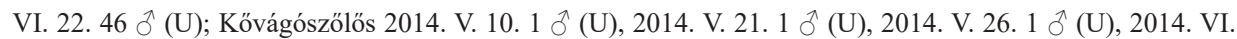
28.3 (GT, U); Kővágótöttös, Cserma-h. 2018. V. 31.1 đ (GT); Örtilos, ártér 1999. VII. 1. 27 đે (U); Örtilos,

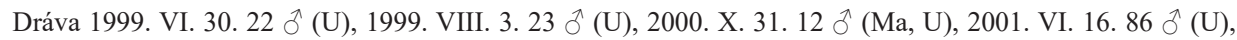

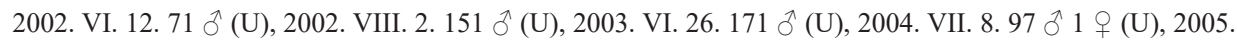

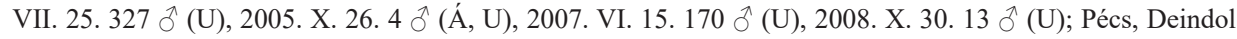

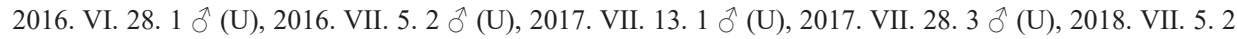
§ (U); Pécs, Mecsekszentkút, Szunyola 2014. VI. 22. 1 đิ (GT, U), 2014. VII. 20.1 (U); Pécs, Nagyárpád,

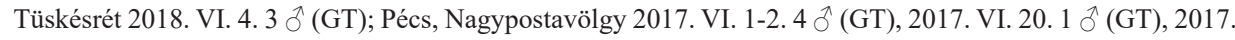

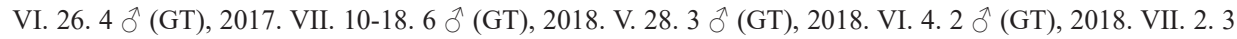

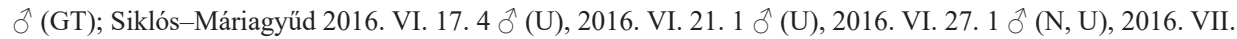

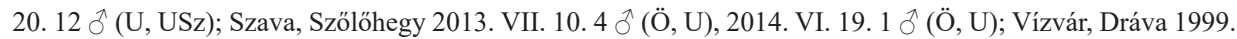

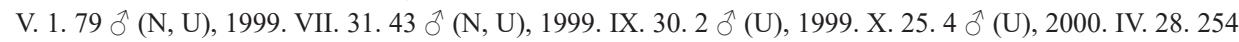

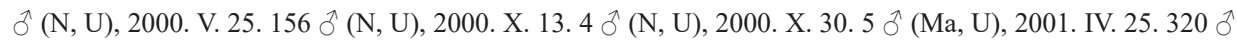

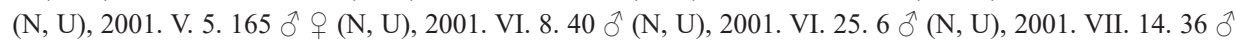

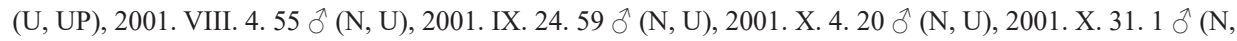

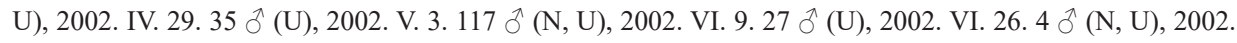

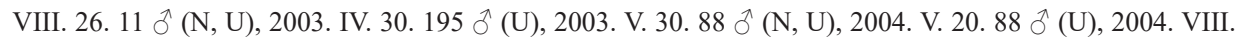

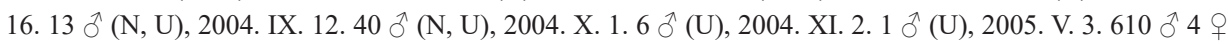

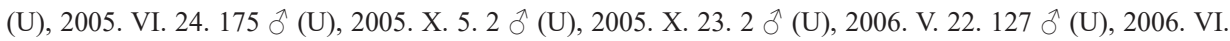

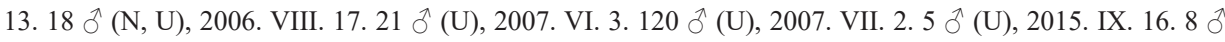
(GÁ, M, U).

Hydropsyche fulvipes (Curtis, 1834) - Abaliget, Nyáras-v. (U \& N 2006); Cserkút (N et al. 1985); Pécs, Éger-völgy (N et al. 1985) - Abaliget, Nyáras-v. 2017. VIII. 26. 8 + (U); Bakonya, Sás-v. 2017. VII. 20. 2 o 6 (GT, U); Cserkút 2011. VI. 29. 1 (U), 2011. VII. 27. 1 (U), 2011. VIII. 18.1 3 \% (U), 2011. VIII.

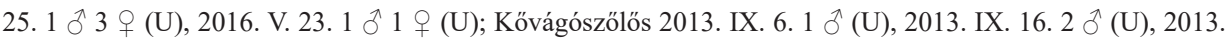
IX. 25. 2 (U), 2014. V. 21. 1 (U), 2014. VIII. 19. 5 § (GT, U); Kövágótöttös, Cserma-h. 2017. VI. 13. 1

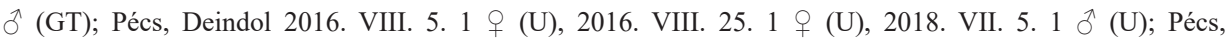
Mecsekszentkút, Szunyola 2014. VI. 29. 1 (U), 2014. VII. 19. 1 ○ (U), 2014. VIII. 26.2 + (GT, U), 2016. VII. 22. 1 ते (GT, U).

Hydropsyche instabilis (Curtis, 1834) - Kercaszomor (U 2004); Magyarszombatfa (U \& N 1992a).

Hydropsyche modesta Navás, 1925 - Alsószenterzsébet (U 2004); Babócsa, ártér (N \& U 1998); Barcs, halastó (N \& U 1995); ); Barcs, Rinya-Ó-Dráva (N \& U 1998); Barcs, szakiskola (N \& U 1998); Barcs, Szilonics-p. (N \& U 1998); Bélavár, Lókai-mező (N \& U 1998); Belezna, Mura (N \& U 1998); Bükkösd, Szentdomján (U \& N 2006); Darány, Nagyberek (N \& U 1995); Diósviszló (N 2000); Drávapalkonya (N \& U 1995); Drávasztára (N \& U 1995, 1998); Kemse, Háromfa (N \& U 1995); Kercaszomor (U 2004); Kerkaszentkirály, Kerka (U 2004); Kisdobsza (N et al. 1985, N \& U 1988); Kisszentmárton, Majláthpuszta (N \& U 1995); Komlósd (N et al. 1985); Magyarföld (U 2004); Magyarszombatfa (U \& N 1992a); Muraszemenye (U 2004); Örtilos, Dráva (N \& U 1995); Patosfa (N \& U 1990); Pécs, Deindol (U \& N 2006); Péterhida (N \& U 1998); Somogyudvarhely, Dombó-csat. (N \& U 1998); Szava (N 2000); Szentborbás (U \& N 1992b); Szentlőrinc (N \& U 1990); Szulimán (N \& U 1990); Tótszerdahely (U 2004); Tótújfalu, Dráva (N \& U 1998); Vejti, Dráva (N \& U 1995); Vízvár, Dráva (N \& U 1998); Vízvár, község (N \& U 1995) - Abaliget, Nyáras-v.

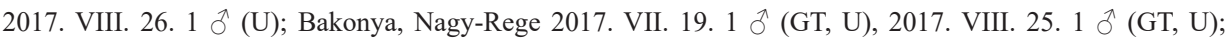
Bakonya, Sás-v. 2017. VII. 20. 2 đ (GT, U); Barcs, Kis-bók 1999. VIII. 5.1 đ (U); Bélavár, Dráva 2003. V.

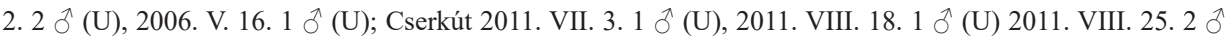




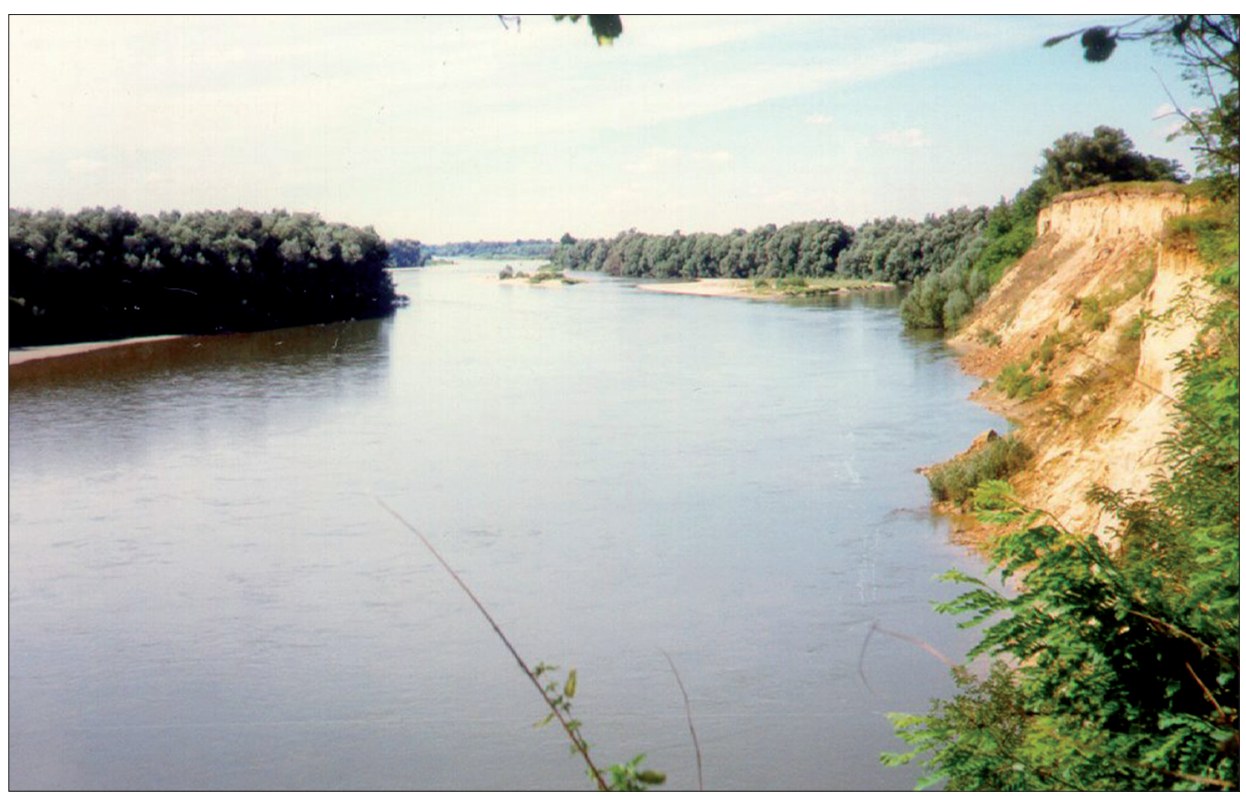

5. ábra: A Dráva Heresznye és Vízvár között, a magaspartról

Fig. 5: Dráva river between Heresznye and Vízvár, seeing from the high bank

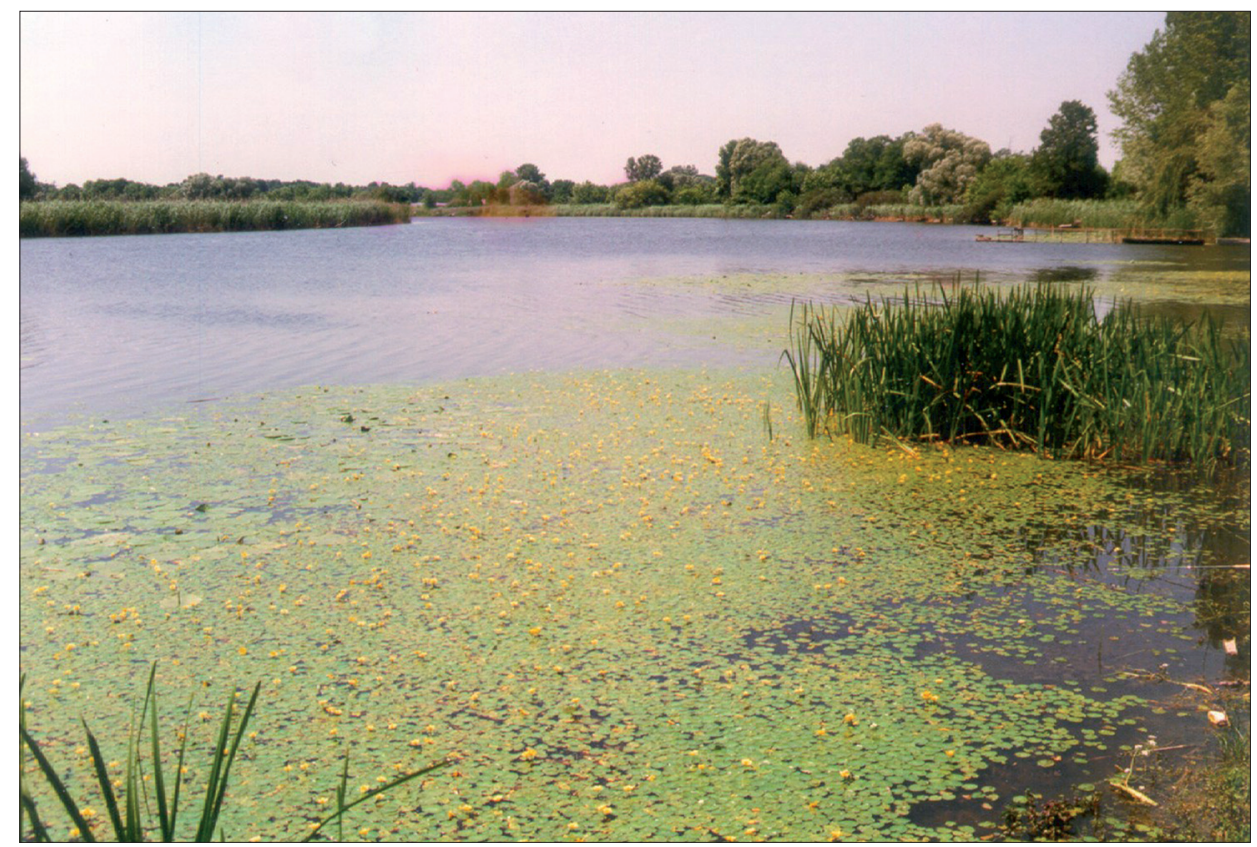

6. ábra: Egy Dráva holtág Mattynál, jelenleg horgászvíz

Fig. 6: An oxbow-lake of Dráva near Matty, recently anglers' lake 


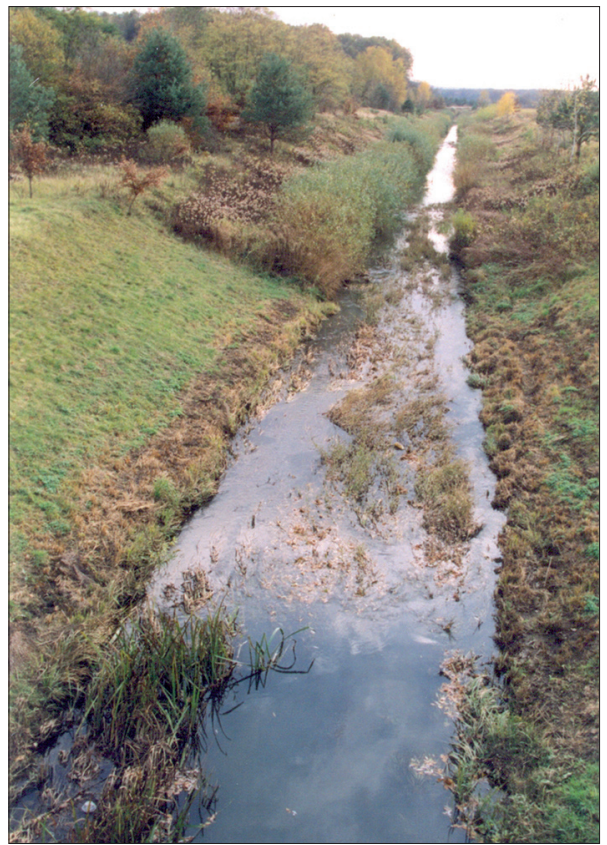

7. ábra: A Kerka folyó Lentitől északra, Bárszentmihályfa közelében, szabályozott, múvi mederrel

Fig. 7: Kerka river with regulated, artifical bed north from Lenti, near Bárszentmihályfa

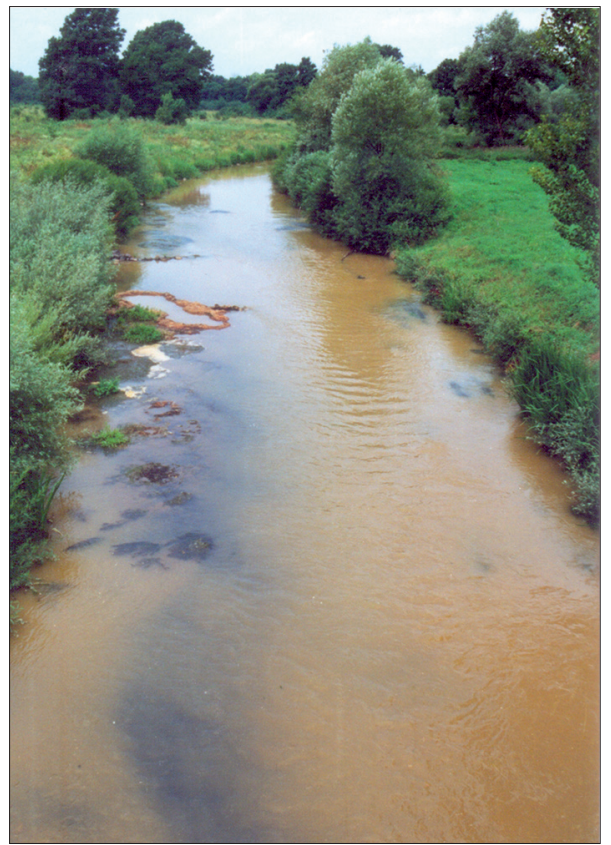

8. ábra: A Kerka Kerkaszentkirálynál, magas vízszintnél

Fig. 8: Kerka river with high water at Kerkaszentkirály

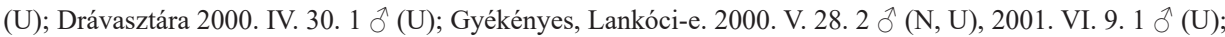
Ibafa, Gyürüfü 2007. VI. 22. 7 (U); Kővágószőlős 2014. VI. 28. 5 ô (GT, U); Kövágótötttös, Cserma-h.

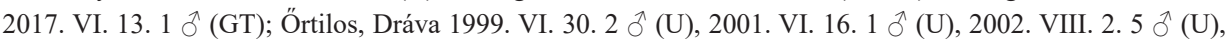
2003. VI. 26. 2 đิ (U); Pécs, Nagyárpád, Tüskésrét 2018. VI. 4.1 đ (GT); Pécs, Nagypostavölgy 2017. VI.

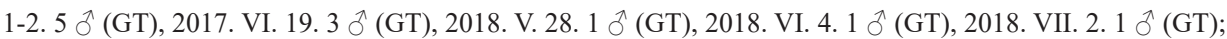
Vízvár, Dráva 1999. V. 1.1 đ (N, U), 1999. VII. 31.2 đ (N, U), 2000. IV. 28.1 đ (N, U), 2000. V. 25.8 (N, U), 2001. IV. 25. 1 (N, U), 2001. V. 5. 2 (N, U), 2001. VI. 8. 2 ๙ (N, U), 2001. VII. 14.1 ô (U, UP),

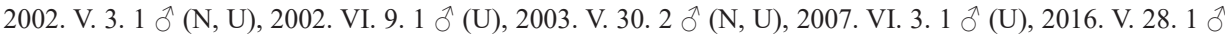
(GÁ, U).

Hydropsyche ornatula McLachlan, 1878 - Babócsa, ártér (N \& U 1998); Barcs, Dráva-part (N \& U 1998); Barcs, Kisbók (N \& U 1998); Barcs, halastó (N 1985a, N \& U 1995); Barcs, szakiskola (N \& U 1998); Bélavár, Dráva (N \& U 1998); Bélavár, Lókai-mező (N \& U 1998); Böhönye (N \& U 1992); Cserkút (N et al. 1985); Csertő (N \& U 1990); „Darány“ (Ujhelyi 1981a); Darány, Kuti őrház (N 1985a, N \& U 1998); Darány, Nagyberek (N 1985a); Drávapalkonya (N \& U 1995); Drávasztára (N \& U 1995); Felsőszentmárton, Mrtvica (N \& U 1998); Gordisa, Mattyi-tó (N \& U 1995); Heresznye (N \& U 1998); Homokszentgyörgy (N \& U 1988); Kemse, Háromfa (N \& U 1995); Kisdobsza (N et al. 1985, N \& U 1988); Kisszentmárton, Majláthpuszta (N \& U 1995); Komlósd (N \& U 1998); „Középrigóc“ (Ujhelyi 1981a); Magyarszombatfa (U \& N 1992a); Örtilos, ártér (N \& U 1998); Örtilos, Dráva (N \& U 1995); Patosfa (N \& U 1990); Pellérd, halastavak (U \& N 2006); Péterhida (N \& U 1998); Potony, Lugi-erdö (N \& U 1995); Siklós, Göntér (N 2000); Somogyapáti (N \& U 1990); Somogyudvarhely, Dombó-csat. (N \& U 1998); Szaporca, Kisinci (N \& U 1998); Szentborbás (U \& N 1992b, N \& U 1998); Szentlörinc (N \& U 1990); Tormafölde (N et al. 1985); Tótszerdahely (U 2004); 
Tótújfalu, Dráva (N \& U 1998); Vejti, Dráva (N \& U 1995, 1998); Vízvár, Dráva (N \& U 1995, 1998); Vízvár, község (N \& U 1995); Zákány (N \& U 1998) - Bélavár, Dráva 2002. VI. 18.3 đ̊ (N, U); Bélavár, Lókai-mező

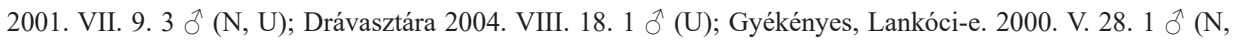

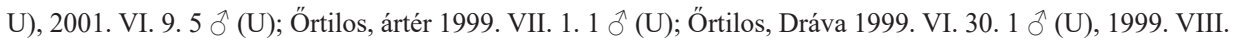

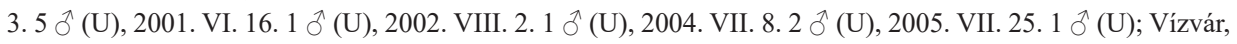

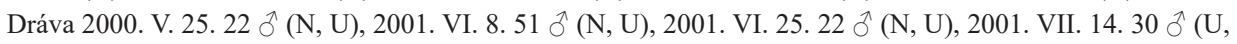
UP), 2001. VIII. 4. 5 ๙ (N, U), 2002. VI. $9.7 \lesssim(U)$, 2002. VIII. 26. 2 ๙ (N, U).

Hydropsyche pellucidula (Curtis, 1834) - Alsószenterzsébet (U 2004); Babócsa, ártér (N \& U 1998); Babócsa, Rinya (N \& U 1998); Barcs, erdészet (N 1985a); Barcs, erdészház (N 1985a); Barcs, halastó (N 1985a); Barcs, Kisbók (N \& U 1998); Barcs, szakiskola (N \& U 1998); Barcs, Szilonics-p. (N \& U 1998); Bélavár, Dráva (N \& U 1998); Bélavár, Kerék-hegy (N \& U 1998); Bélavár, Lókai-mező (N \& U 1998); Belezna, Mura (N \& U 1998); Böhönye (N \& U 1992); Csesztreg-Kerkaújfalu (U 2004); Csörnyefölde (N et al. 1985); Darány, Kuti-őrház (N \& U 1998); Diósviszló (N 2000); Drávaszentes (N \& U 1998); Drávasztára (N \& U 1995); Gyékényes, kavicsbányató (N \& U 1995); Gyékényes, Lankóci-e. (N \& U 1998); Heresznye (N \& U 1998); Kemse, Háromfa (N \& U 1995); Kisdobsza (N et al. 1985, N \& U 1988); Kisszentmárton, Majláthpuszta (N \& U 1995); „Középrigóc“ (Ujhelyi 1981a); Magyarszombatfa (U \& N 1992a); Örtilos, ártér (N \& U 1998); Örtilos, Dráva (N \& U 1998); Pécs, Éger-völgy (N et al. 1985); Péterhida (N \& U 1998); Potony (N \& U 1998); Somogyapáti (N \& U 1990); Somogyudvarhely, Dombó-csat. (N \& U 1998); Szentborbás (U \& N 1992b); Tormafölde (N et al. 1985); Tótszerdahely (U 2004); Tótújfalu, Dráva (N \& U 1998); Vejti, Dráva (N \& U 1995); Vízvár, Dráva (N \& U 1995, 1998); Vízvár, község (N \& U 1995); Zákány (N \& U 1998); Zalabaksa (U 2004) - Barcs, Kis-bók 1999. VIII. 5. 1 đ (U); Bélavár, Dráva 2002. VI. 18. 2 đิ (N, U), 2003. V. 2.8 đ(U), 2003. VI. 12. 23 đ(N, U), 2006. V. 16. 3 đ(U); Bélavár, Lókai-mező 1999. V. 11.1 (U),

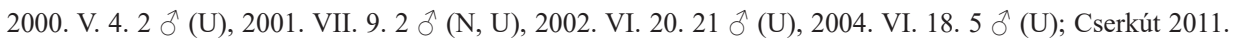
VI. 18. 1 đ(U); Darány, Nagyberek 1999. V. 19. 1 đ(U); Drávasztára 2004. VIII. 18. 1 đ(U); Gyékényes, Lankóci-e. 2000. V. 28. $3 \delta(\mathrm{N}, \mathrm{U}), 2001$. VI. $9.7 \delta(\mathrm{U}), 2002$. V. 2.1 (U), 2003. VI. 17. $3 \delta$ (N, U), 2004.

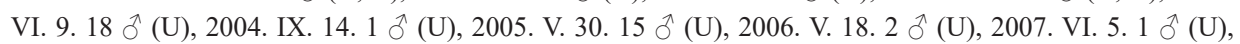

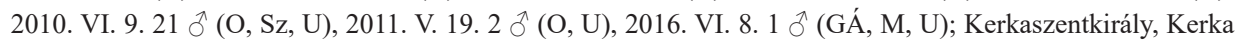

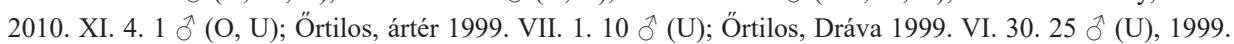

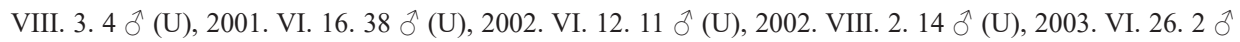

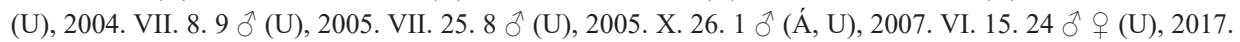
X. 21.1 đิ (Szi, Mo, U); Siklós-Máriagyüd 2016. VI. 27. 1 đ (N, U); Vízvár, Dráva 1998. IV. 28. 1 đ (N, U),

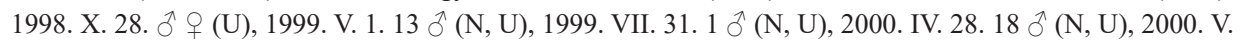

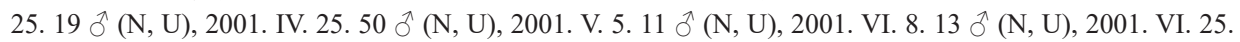

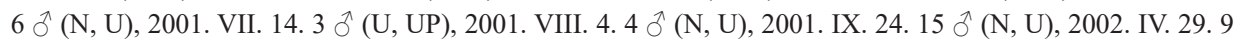

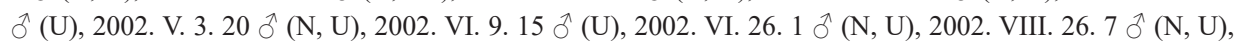
2003. IV. 30. $68 \widehat{\jmath}(\mathrm{U}), 2003$. V. 30. $43 \hat{\jmath}(\mathrm{N}, \mathrm{U}), 2004$. V. 20. $6 \widehat{\jmath}(\mathrm{U}), 2004$. VIII. 16. $9 \widehat{\delta}(\mathrm{N}, \mathrm{U}), 2004$. IX.

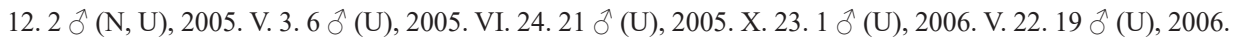

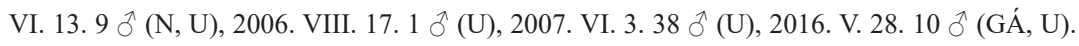

Hydropsyche saxonica McLachlan, 1884 - Almamellék, Sas-rét (N \& U 1990); Alsószenterzsébet (U 2004); Bakonya, Sás-v. (U \& N 2006); Belezna, Kakonyapuszta (N \& U 1998); Böhönye (N \& U 1992); CsesztregKerkaújfalu (U 2004); Csömödér (U 2004); Darány, Kuti-örház (N \& U 1998); Hegyszentmárton (N 2000); Hedrehely (N et al. 1985); Hetvehely, Bükkösdi-v. (U \& N 2006); Hetvehely, Káni-p. (N \& U 1990); Kercaszomor (U 2004); Kerkaszentkirály, Kerka (U 2004); Kisdobsza (N et al. 1985, N \& U 1988); Magyarszombatfa (U \& N 1992a); Nova-Zágorhida, Cserta (U 2004); Pécs, Éger-v. (U \& N 2006); Porrogszentpál, Rigócz-p. (N \& U 1998); Szava (N 2000); Szentgyörgyvölgy (U 2004); Szentlőrinc (N \& U 1990); Szulimán (N \& U 1990); Zákány (N \& U 1998) - Cserkút 2011. V. 20. 3 ð 2 ○ (U), 2011. V. 25. 2

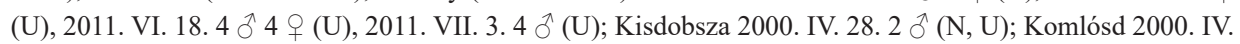

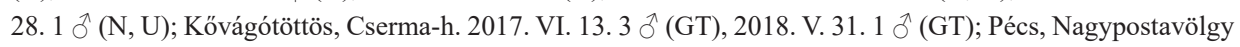

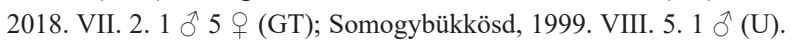


Hydropsyche siltalai Döhler, 1963 - Bükkösd, Szentdomján (U \& N 2006); Dobri (U 2004); Kercaszomor (U 2004); Magyarföld (U 2004); Örtilos, Dráva (U 2005); Vízvár, Dráva (U 2005) - Örtilos, Dráva 2004 . VII. 8. 1 đ(U); Vízvár, Dráva 2001. VI. 8. 1 đ (N, U).

\section{Polycentropodidae}

Neureclipsis bimaculata (Linnaeus, 1758) - Almamellék, Sas-rét (N \& U 1990); Babócsa, Rinya (N \& U 1998); Barcs, erdészet (N 1985a); Barcs, halastó (N 1985a, N \& U 1995); Barcs, Kisbók (N \& U 1998); Barcs, Rinya-Ó-Dráva (N \& U 1998); Barcs, szakiskola (N \& U 1998); Barcs, Szilonics-p. (N \& U 1998); Bélavár, Dráva (N \& U 1998); Bélavár, Kerék-hegy (N \& U 1998); Bélavár, Lókai-mező (N \& U 1998); Böhönye (N \& U 1992); Csarnóta (N 2000); Csertő (N \& U 1990); Darány, Kuti őrház; (N 1985a, N \& U 1998); Darány, Nagyberek (N \& U 1995); Diósviszló (N 2000); Drávapalkonya (N \& U 1995); Drávaszabolcs, Holt-Feketevíz (N \& U 1998); Drávasztára (N \& U 1995, 1998); Felsőszentmárton, Korcsina-csat. (N \& U 1998); Felsőszentmárton, Mrtvica (N \& U 1998); Gordisa, Mattyi-tó (N \& U 1995); Gyékényes, kavicsbányató (N \& U 1995); Gyékényes, Lankóci-e. (N \& U 1998); Kemse, Háromfa (N \& U 1995); Kercaszomor (U 2004); Kerkaszentkirály, Kerka (U 2004); Kisdobsza (N et al. 1985, N \& U 1988); Kisszentmárton, Majláthpuszta (N \& U 1995); Komlósd (N \& U 1998); „Középrigóc“ (Ujhelyi 1981a); Magyarszombatfa (U \& N 1992a); Örtilos, Dráva (N \& U 1995); Patosfa (N \& U 1990); Pécs, Deindol (U \& N 2006); Pellérd, halastavak (U \& N 2006); Péterhida (N \& U 1998); Potony, Lugi-erdő (N \& U 1995); Rédics, Kebele-p. (U 2004); Siklós, Göntér (N 2000); Somogyapáti (N \& U 1990); Somogyudvarhely, Dombó-csat. (N \& U 1998); Szaporca, Kisinci (N \& U 1998); Szentborbás (U \& N 1992b, N \& U 1998); Szentlőrinc (N \& U 1990); Szulimán (N \& U 1990); Vejti, Dráva (N \& U 1995, 1998); Vízvár, Dráva (N \& U 1995, 1998); Vízvár, község (N \& U 1995) - Barcs, Kis-bók 1999. VIII. 5. 2 q (U); Bélavár, Dráva 2002. VI. 18. 2 đ 9 (N, U), 2003. VI. 12. 2 § 1 \% (N, U), 2005. VIII. 2. 1 q (U); Bélavár, Lókai-mező 2001. VII. 9. 1 † (N, U); Darány, Nagyberek 1999. V. 19. 1 (U); Drávapalkonya 1999. VI. 28. 3 đ 5 q (U); Drávasztára 1999. VI. 12.1 đ 7 q (N, U), 1999. VIII. 9.

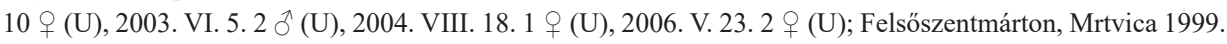

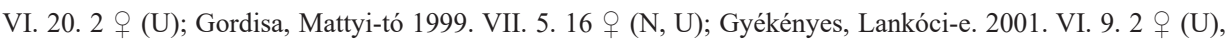
2004. VI. 9.3 (U); Örtilos, Dráva 1999. VI. 30.1 (U), 1999. VIII. 3.1 đ 1 (U), 2001. VI. 16. 2 q (U),

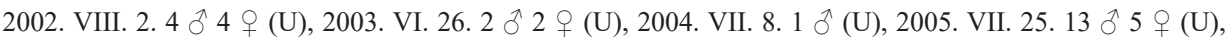
2006. X. 26. 1 † (Á, U), 2007. VI. 15. 5 đ 18 † (U); Pécs, Nagypostavölgy 2017. VI. 20. 1 † (GT); Siklós-

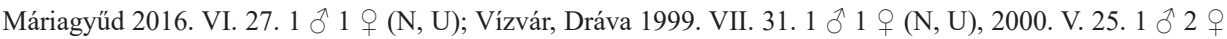
$(\mathrm{N}, \mathrm{U}), 2000$. X. 13. 1 q (N, U), 2001. VI. 8.1 \& (N, U), 2001. VI. 25. 2 q (N, U), 2001. VII. 14. 1 (U, UP), 2001. IX. 24. 1 (N, U), 2002. VI. 9.2 q (U), 2002. VIII. 26. 2 ^ 1 (N, U), 2004. V. 20. 3 (U),

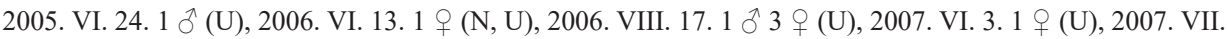

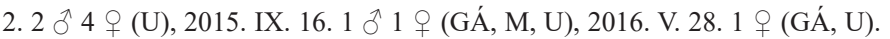

Plectrocnemia brevis McLachlan, 1871 - Bakonya, Erdészház (N et al. 1985); Magyarszombatfa (U \& N 1992a); Pécs, Deindol (U \& N 2006) - Pécs, Mecsekszentkút, Szunyola 2014. V. 20.1 q (U).

Plectrocnemia conspersa (Curtis, 1834) - Abaliget, Nyáras-v. (N et al. 1985, U \& N 2006); Almamellék, Sas-rét (N \& U 1990); Alsószenterzsébet (U 2004); Bakonya, Sás-v. (U \& N 2006); Bükkösd, Bükkösdi-v. (U \& N 2006); Cserkút (N et al. 1985); Diósviszló (N 2000); Hetvehely, Káni-p. (N \& U 1990); Hetvehely, Nyáras-v. (U \& N 2006); Hetvehely, Sás-v. (U \& N 2006); Kővágószőlős (N et al. 1985); Magyarszombatfa (U \& N 1992a); Örtilos, Dráva (N \& U 1995); Pécs, Deindol (U \& N 2006); Somogyudvarhely, források (N \& U 1998); Szava (N 2000) - Abaliget, Nyáras-v. 2017. VIII. 26. 1 q (U); Cserkút 2011. IV. 3.1 § (U), 2011.

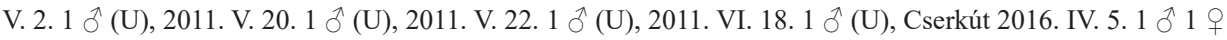

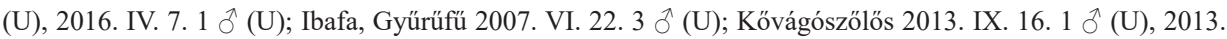

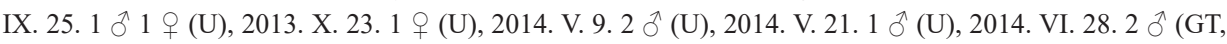
U); Kővágótöttös, Cserma-h. 2017. VI. 13. 1 đ(GT); Pécs, Deindol 2011. V. 26. 1 đิ (U) 2011. V. 30.1 q (U);

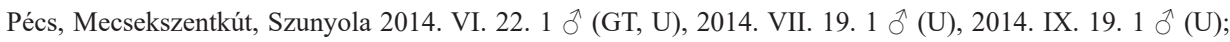
Pécs, Nagypostavölgy 2018. V. 1-13. 1 đ(GT).

Polycentropus flavomaculatus (Pictet, 1834) - Magyarszombatfa (U \& N 1992a). 
Polycentropus irroratus Curtis, 1834 - Csesztreg-Kerkaújfalu (U 2004); Kercaszomor (U 2004); Lenti, Bárszentmihályfa (U 2004); Magyarszombatfa (U \& N 1992a); Vejti, Dráva (N \& U 1995).

Holocentropus dubius (Rambur, 1842) - Alsószenterzsébet (U 2004); Bélavár, Dráva (N \& U 1998); Bélavár, Lókai-mező (N \& U 1998); Belezna, Mura (N \& U 1998); Gyékényes, Lankóci-e. (N \& U 1998); Somogyudvarhely, Dombó-csat. (N \& U 1998); Szentborbás (U \& N 1992b) - Bélavár, Dráva 2006. V. 16. 1 § (U); Bélavár, Lókai-mező 2002. VI. 20. 2 † (U), 2004. VI. 18. 1 đ 1 \& (U); Darány, Nagyberek 2000. VI. 6. 1 q (N, U); Gyékényes, Lankóci-e. 2000. V. 28.2 of 1 (N, U), 2001. VI. 9.1 (U), 2004. VI. 9.1 (U),

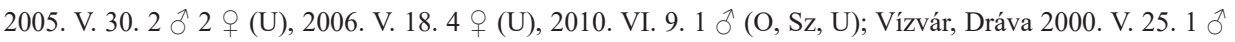

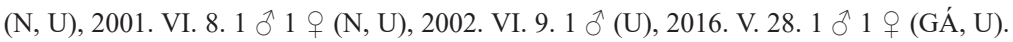

Holocentropus picicornis (Stephens, 1836) - Babócsa, ártér (N \& U 1998); Barcs, halastó (N 1985a, N \& U 1995); Barcs, halastó I. (N \& U 1998); Bélavár, Dráva (N \& U 1998); Bélavár, Lókai-mező (N \& U 1998); Csertő (N \& U 1990); Darány, Nagyberek (N \& U 1995); Drávapalkonya (N \& U 1995); Drávaszabolcs, HoltFekete-víz (N \& U 1998); Drávasztára (N \& U 1995); Gordisa, Mattyi-tó (N \& U 1995); Gyékényes, Lankóci-e. (N \& U 1998); Kisdobsza (N \& U 1988); Kisszentmárton, Majláthpuszta (N \& U 1995); Matty, Keselyősfapuszta (N \& U 1998); Örtilos, Dráva (N \& U 1995); Patosfa (N \& U 1990); Somogyapáti (N \& U 1990); Szaporca, Kisinci (N \& U 1998); Szentborbás (U \& N 1992b); Szentlőrinc (N \& U 1990); Szulimán (N \& U 1990 - Almamellék, Almás-p. 1998. VII. 19. 21 ㅇ (U); Bélavár, Dráva 2006. V. 16. 1 † (U); Bélavár, Lókai-mező 2002. VI. 20. 4 ๆ (U); Gordisa, Mattyi-tó 1999. VII. 5.2 † (N, U); Gyékényes, Lankóci-e. 2000.

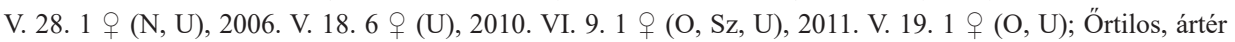

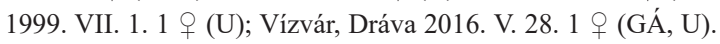

Holocentropus stagnalis (Albarda, 1874) - Barcs, halastó (N 1985a, N \& U 1995); Darány, Nagyberek (N 1985a, N \& U 1995, 1998) - Darány, Nagyberek 1999. V. 19. 1 đ̊ 3 q (U); Gordisa, Mattyi-tó 1999. VII. 5.1 q $(\mathrm{N}, \mathrm{U})$.

Cyrnus crenaticornis (Kolenati, 1859) - Barcs, halastó (N 1985a); Barcs, Rinya-Ó-Dráva (N \& U 1998); Barcs, szakiskola (N \& U 1998); Bélavár, Dráva (N \& U 1998); Bélavár, Lókai-mező (N \& U 1998); Böhönye (N \& U 1992); Csesztreg-Kerkaújfalu (U 2004); Darány, Nagyberek (N 1985a, N \& U 1998); Drávasztára (N \& U 1995, 1998); Gyékényes, Lankóci-e. (N \& U 1998); Kerkaszentkirály, Kerka (U 2004); Kisdobsza (N et al. 1985, N \& U 1988); Kisszentmárton, Majláthpuszta (N \& U 1995); Komlósd (N et al. 1985); Magyarszombatfa (U \& N 1992a); Potony, Lugi-erdő (N \& U 1995); Somogyudvarhely (N et al. 1985); Somogyudvarhely, Dombó-csat. (N \& U 1998); Szentborbás (U \& N 1992b, 1998); Szulimán (N \& U 1990); Tótújfalu, Dráva (N \& U 1998); Vejti, Dráva (N \& U 1998); Vízvár, Dráva (N \& U 1995); Vízvár, község (N \& U 1995) - Bélavár, Dráva 2002. VI. 18. 2 † (N, U); Bélavár, Lókai-mező 1999. V. 11. 15 đ 2 q (U), 2001.

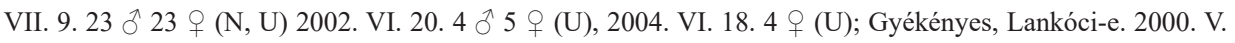

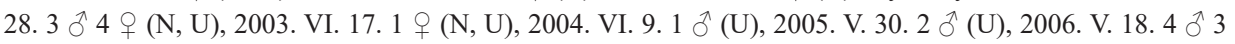

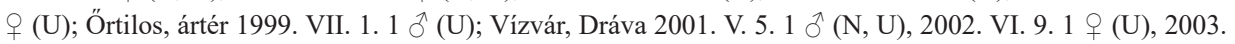
V. 30.1 Ґ 1 (N, U).

Cyrnus trimaculatus (Curtis, 1834) - Babócsa, ártér (N \& U 1998); Bakonya, Sás-v. (U \& N 2006); Barcs, Kisbók (N \& U 1998); Bélavár, Lókai-mező (N \& U 1998); Bükkösd, Bükkösdi-v. (U \& N 2006); Bükkösd, Szentdomján (U \& N 2006); Csesztreg-Kerkaújfalu (U 2004); Drávasztára (N \& U 1995); Felsőszentmárton, Korcsina-csat. (N \& U 1998); Hetvehely, Bükkösdi-v. (U \& N 2006); Kercaszomor (U 2004); Kerkaszentkirály, Kerka (U 2004); Lenti, Bárszentmihályfa (U 2004); Magyarföld (U 2004); Magyarszombatfa (U \& N 1992a); Rédics, Kebele-p. (U 2004); Somogyudvarhely, Dombó-csat. (N \& U 1998); Szentborbás (U \& N 1992b); Szentgyörgyvölgy (U 2004); Tormafölde (U 2004); Vejti, Dráva (N \& U 1995); Vízvár, Dráva (N \& U 1995 , 1998) - Bélavár, Lókai-mező 2001. VII. 9.1 † (N, U), 2002. VI. 20. 1 đ (U); Drávasztára 2001. V. 4.1 đ (N, U), 2003. VI. 5.1 (U); Gyékényes, Lankóci-e. 2000. V. 28. 3 † (N, U), 2011. V. 19. 1 q (O, U), 2016. VI.

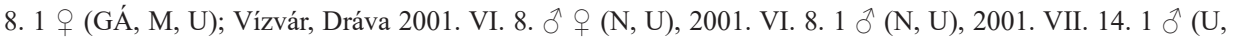

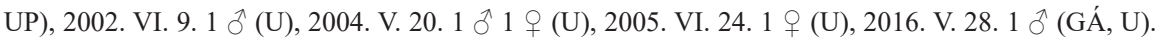




\section{Psychomyidae}

Psychomyia pusilla (Fabricius, 1781) - Alsószenterzsébet (U 2004); Babócsa, Rinya (N \& U 1998); Barcs, halastó (N 1985a, N \& U 1995); Barcs, halastó I. (N \& U 1998); Barcs, Kisbók (N \& U 1998); Barcs, RinyaÓ-Dráva (N \& U 1998); Barcs, szakiskola (N \& U 1998); Barcs, Szilonics-p. (N \& U 1998); Bélavár, Dráva (N \& U 1998); Bélavár, Lókai-mező (N \& U 1998); Belezna, Mura (N \& U 1998); Bükkösd, Bükkösdi-v. (U \& N 2006); Bükkösd, Szentdomján (U \& N 2006); Csesztreg-Kerkaújfalu (U 2004); Darány, Nagyberek (N 1985a, N \& U 1998); Dobri (U 2004); Drávapalkonya (N \& U 1995, 1998); Drávasztára (N \& U 1995, 1998); Drávatamási (N \& U 1998); Felsőszentmárton, Mrtvica (N \& U 1998); Gordisa, Mattyi-tó (N \& U 1995); Gyékényes, Lankóci-e. (N \& U 1998); Heresznye (N \& U 1998); Hetvehely, Bükkösdi-v. (U \& N 2006); Kemse, Háromfa (N \& U 1995); Kercaszomor (U 2004); Kerkaszentkirály, Kerka (U 2004); Kisdobsza (N \& U 1988); Magyarföld (U 2004); Magyarszombatfa (U \& N 1992a); Muraszemenye (U 2004); Örtilos, ártér (N \& U 1998); Örtilos, Dráva (N \& U 1995, 1998); Örtilos, Új-Zrínyi-vár (N \& U 1998); Patosfa (N \& U 1990); Potony, Lugi-erdő (N \& U 1995); Rédics, Kebele-p. (U 2004); Somogyudvarhely, Dombó-csat. (N \& U 1998); Szaporca, Kisinci (N \& U 1998); Szentborbás (U \& N 1992b, N \& U 1998); Tótszerdahely (U 2004); Tótújfalu, Dráva (N \& U 1998); Vejti, Dráva (N \& U 1995, 1998); Vízvár, Dráva (N \& U 1995, 1998); Vízvár, község (N \& U 1995); Zalabaksa (U 2004) - Barcs, Szilonics-p. 1999. V. 19. 2 đ 2 o (U); Bélavár, Dráva

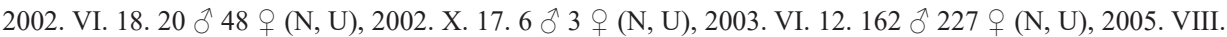

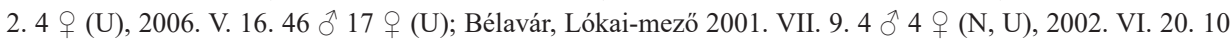

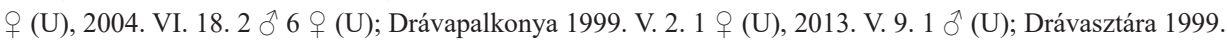

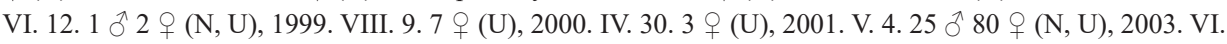

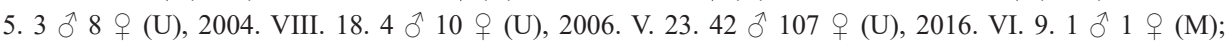
Gyékényes, Lankóci-e. 2000. V. 28. 5 ð 16 (N, U), 2001. VI. 9.40 万 52 q(U), 2003. VI. 17.1 (N, U),

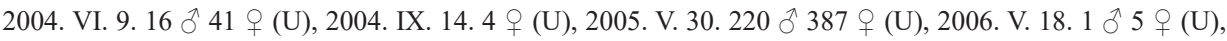

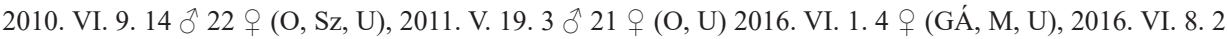
đ (GÁ, M, U); Örtilos, ártér 1999. VII. 1. 20 đ̊ q (U); Örtilos, Dráva 1999. VI. 30.7 đิ 26 q (U), 1999. VIII.

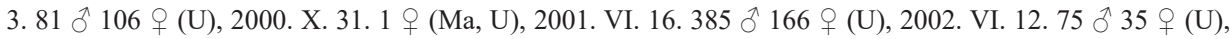

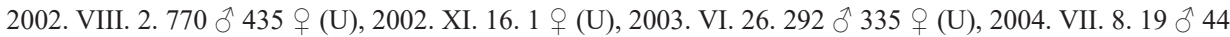

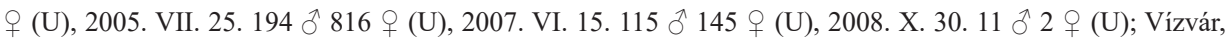

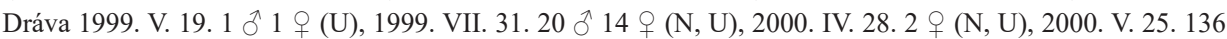

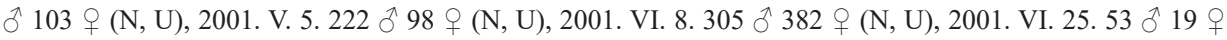

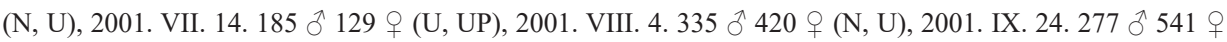

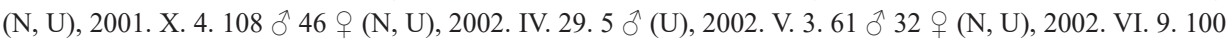

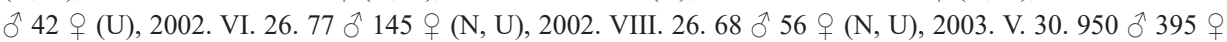

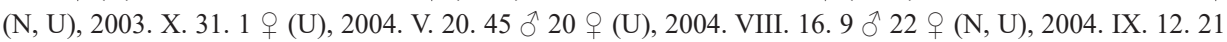

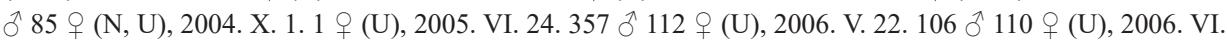

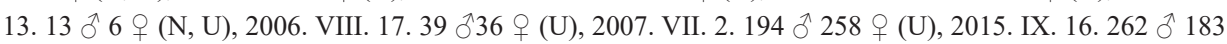
q (GÁ, M, U), 2016. V. 28. 59 Ґ 43 ㅇ (GÁ, U).

Lype phaeopa (Stephens, 1836) - Babócsa, Rinya (N \& U 1998); Barcs, Szilonics-p. (N \& U 1998); Bélavár, Dráva (N \& U 1998); Bélavár, Lókai-mező (N \& U 1998); Csesztreg-Kerkaújfalu (U 2004); Drávasztára (N \& U 1995, 1998); Drávatamási (N \& U 1995); Gyékényes, kavicsbányató (N \& U 1995); Őrtilos, Dráva (N \& U 1995); Patosfa (N \& U 1990); Szentborbás (U \& N 1992b); Vejti, Dráva (N \& U 1995, 1998); Vízvár, Dráva (N \& U 1995, 1998) - Bélavár, Dráva 2005. VIII. 2.1 đ (U), 2006. V. 16.1 q (U); Bélavár, Lókai-mező 1999.

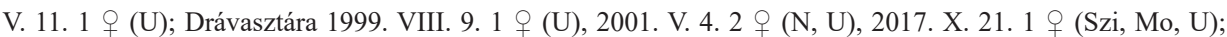
Vízvár, Dráva 1999. V. 1.3 đ (N, U), 1999. V. 19. 4 đ 1 q (U), 2000. IV. 28. 1 đ 1 q (N, U), 2000. X. 30. 1

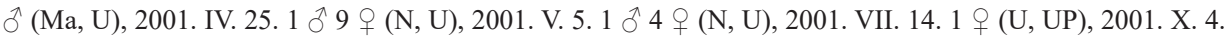

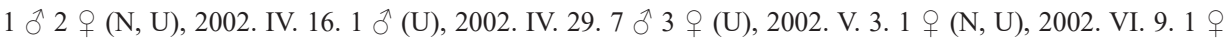
(U), 2002. VIII. 26. 1 \ 7 (N, U), 2003. IV. 30. 1 q (U), 2003. V. 30.1 (N, U), 2004. VIII. 16.4 (N, U), 2004. IX. 12. 1 ઈ 1 (N, U), 2005. V. 3.2 (U), 2006. V. 22. 1 q (U), 2006. VI. 13. 1 (N, U), 2006. VIII. 17. $1 \precsim(\mathrm{U}), 2007$. VI. 3. $170 \precsim 35$ 으 (U), 2015. IX. 16. 2 q (GÁ, M, U). 
Lype reducta (Hagen, 1868) - Babócsa, ártér (N \& U 1998); Babócsa, Rinya (N \& U 1998); Bélavár, Lókaimező (N \& U 1998); Belezna, Kakonyapuszta (N \& U 1998); Csesztreg-Kerkaújfalu (U 2004); Hetvehely, Bükkösdi-v. (U \& N 2006); Hetvehely, Káni-p. (N \& U 1990); Hetvehely, Nyáras-v. (N et al. 1985); Homokszentgyörgy (N \& U 1988); Komlósd (N \& U 1998); Lad (N \& U 1990); Magyarföld (U 2004); Magyarszombatfa (U \& N 1992a); Őrtilos, Dráva (N \& U 1995); Örtilos, Új-Zrínyi-vár (N \& U 1998); Pécs, Éger-v. (U \& N 2006); Porrogszentpál, Rigócz-p. (N \& U 1998); Somogyudvarhely, források (N \& U 1998); Szentborbás (U \& N 1992b); Szentgyörgyvölgy (U 2004); Vejti, Dráva (N \& U 1998); Zákány (N \& U 1998)

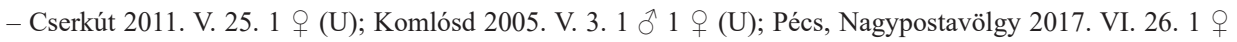
(GT); Vízvár, Dráva 1999. V. 1. 1 §ิ (N, U).

Tinodes pallidulus McLachlan, 1878 - Abaliget, Nyáras-v. (U \& N 2006); Bakonya, Sás-v. (U \& N 2006); Komlósd (U 2005) - Cserkút 2011. VI. 5. 2 ઈ(U), 2011. VIII. 25. 2 q (U).

Tinodes unicolor (Pictet, 1834) - Bakonya, Sás-v. 2017. VII. 20. 1 đ 1 q (GT, U); Pécs, Deindol 2016. VIII.

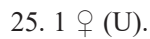

\section{Ecnomidae}

Ecnomus tenellus (Rambur, 1842) - Abaliget, Nyáras-v. (U \& N 2006); Almamellék, Sas-rét (N \& U 1990); Alsószenterzsébet (U 2004); Babócsa, ártér (N \& U 1998); Barcs, halastó (N 1985a, N \& U 1995); Barcs, halastó I. (N \& U 1998); Barcs, Kisbók (N \& U 1998); Barcs, Rinya-Ó-Dráva (N \& U 1998); Barcs, szakiskola (N \& U 1998); Bélavár, Dráva (N \& U 1998); Bélavár, Lókai-mező (N \& U 1998); Belezna, Kakonyapuszta (N \& U 1998); Belezna, Mura (N \& U 1998); Böhönye (N \& U 1992); Bükkösd, Bükkösdi-v. (U \& N 2006); Bükkösd, Szentdomján (U \& N 2006); Csertő (N \& U 1990); Csesztreg-Kerkaújfalu (U 2004); Darány, Kuti őrház (N 1985a); Darány, Nagyberek (N 1985a, N \& U 1995, 1998); Dobri (U 2004); Drávapalkonya (N \& U 1995, 1998); Drávaszabolcs, Holt-Fekete-víz (N \& U 1998); Drávasztára (N \& U 1995, 1998); Drávatamási (N \& U 1998); Felsőszentmárton, Korcsina-csat. (N \& U 1998); Felsőszentmárton, Mrtvica (N \& U 1998); Gordisa, Mattyi-tó (N \& U 1995); Gyékényes, kavicsbányató (N \& U 1995); Gyékényes, Lankóci-e. (N \& U 1998); Heresznye (N \& U 1998); Hetvehely, Nyáras-v. (U \& N 2006); Hetvehely, Sás-v. (U \& N 2006); Homokszentgyörgy (N \& U 1988); Kercaszomor (U 2004); Kerkaszentkirály, Kerka (U 2004); Kisdobsza (N et al. 1985, N \& U 1988); Komlósd (N \& U 1998); „Középrigóc“ (Ujhelyi 1981a); Kisszentmárton, Majláthpuszta (N \& U 1995); Magyarföld (U 2004); Magyarszombatfa (U \& N 1992a); Muraszemenye (U 2004); Patosfa (N \& U 1990); Örtilos, ártér (N \& U 1995, 1998); Örtilos, Dráva (N \& U 1995); Pécs, Deindol (U \& N 2006); Pellérd, halastavak (U \& N 2006); Potony, Lugi-erdő (N \& U 1995); Rédics, Kebele-p. (U 2004); Somogyapáti (N \& U 1990); Somogyudvarhely, Dombó-csat. (N \& U 1998); Szaporca, Kisinci (N \& U 1998); Szava (N 2000); Szentborbás (U \& N 1992b, N \& U 1998); Szentlörinc (N \& U 1990); Szulimán (N \& U 1990); Tormafölde (N et al. 1985); Tótszerdahely (U 2004); Tótújfalu, Dráva (N \& U 1998); Vejti, Dráva (N \& U 1995); Vízvár, Dráva (N \& U 1995, 1998); Vízvár, község (N \& U 1995); Zákány (N \& U 1998); Zalabaksa (U 2004) - Almamellék, Almás-p. 1998. VII. 19. 2 q (U); Barcs, Kis-bók 1999. VIII. 5.175 ð 160

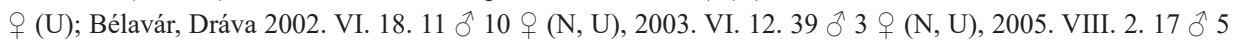

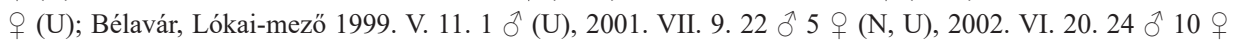

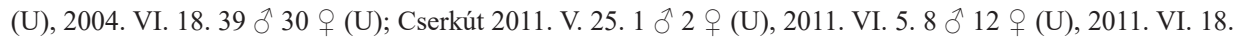

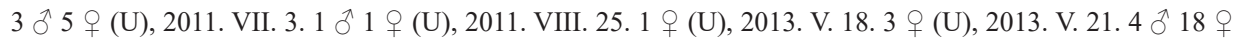

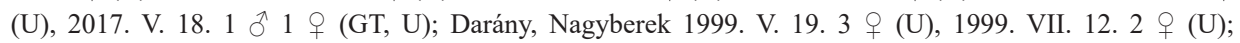
Drávapalkonya 1999. VI. 28. 7 đ(U); Drávasztára 1999. VI. 12. 9 đ 4 q (N, U), 1999. VIII. 9. 1 q (U), 2000.

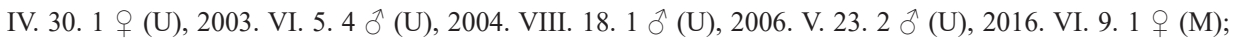
Felsőszentmárton, Mrtvica 1999. VI. 20. 13 ð 26 ㅇ (U); Gordisa, Mattyi-tó 1999. VII. 5. 47 § 72 q (N, U),

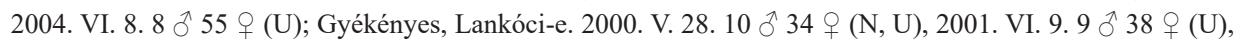

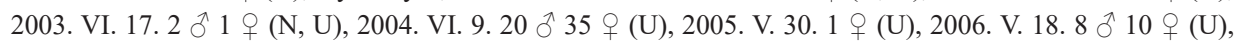

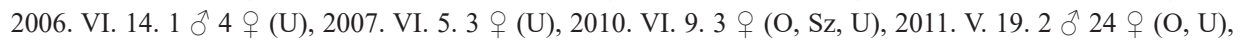
2016. VI. 1.6 đ 24 ๆ (GÁ, M, U), 2016. VI. 8. 4 đ 28 (GÁ, M, U); Ibafa, Gyürüfü 2007. VI. 22. 1 q (U);

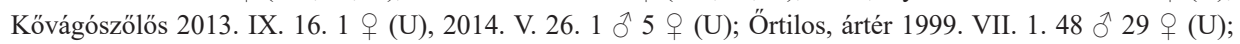

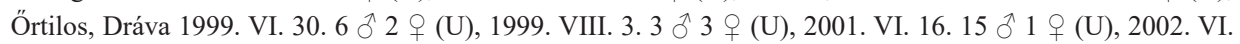




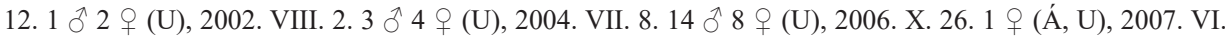
15. 14 万 6 (U); Pécs, Mecsekszentkút, Szunyola 2014. VI. 22. 1 q (GT, U); Pécs, Nagypostavölgy 2017. VI. 1-2. 1 (GT), 2018. V. 1-13. 2 (GT); 2018. V. 28. 1 † (GT); Siklós-Máriagyüd 2016. VI. 21. 1 $(\mathrm{U})$; Siklós, Csukma-h. 2015. V. 8.1 q (U); Somogyudvarhely 1999. V. 19. 1 § 1 q (U), 1999. VIII. 4. $114 \delta 68$

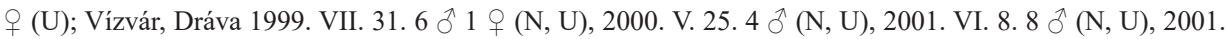

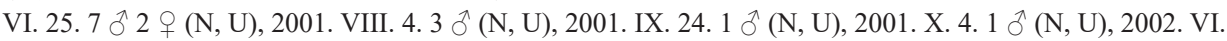

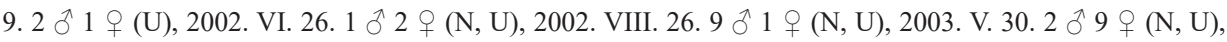

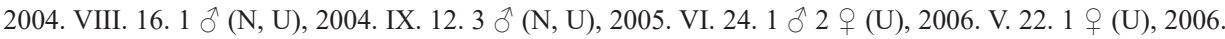

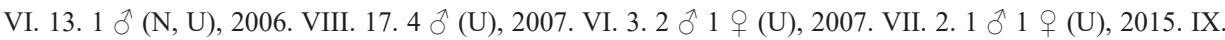
16. 9 え (GÁ, M, U), 2016. V. 28. 3 ๙ิ (GÁ, U).

\section{Phryganeidae}

Trichostegia minor (Curtis, 1834) - Babócsa, ártér (N \& U 1998); Barcs, Csikota (N 1985a); Barcs, erdészet (N 1985a); Barcs, halastó (N 1985a); Barcs, Kisbók (N \& U 1998); Barcs, Rinya-Ó-Dráva (N \& U 1998); Barcs, szakiskola (N \& U 1998); Bélavár, Dráva (N \& U 1998); Bélavár, Lókai-mező (N \& U 1998); Böhönye (N \& U 1992); Darány, Nagyberek (N 1985a, N \& U 1995, 1998); Drávasztára (N \& U 1998); Gyékényes, Lankóci-e. (N \& U 1998); Homokszentgyörgy (N \& U 1988); Kemse, Háromfa (N \& U 1995); Kisdobsza (N et al. 1985, N \& U 1988); Komlósd (N et al. 1985); „Középrigóc“ (Ujhelyi 1981a); Magyarszombatfa (U \& N 1992a); Matty, Keselyősfapuszta (N \& U 1998); Örtilos, Dráva (N \& U 1995); Somogyudvarhely, Dombócsat. (N \& U 1998); Szaporca, Kisinci (N \& U 1998); Szentborbás (N \& U 1998); Vejti, Dráva (N \& U 1995) - Almamellék, Almás-p. 1998. VII. 19. 1 đ (U); Barcs, Kis-bók 1999. VIII. 5.1 đ (U); Barcs, Rinya-Ó-Dráva 1999. V. 19. 1 đ (U); Bélavár, Lókai-mező 2001. VII. 9. 1 † (N, U); Darány, Nagyberek 1998. VI. 12.1 1

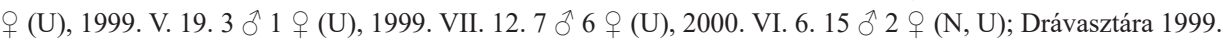

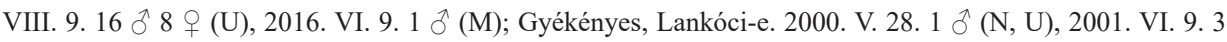

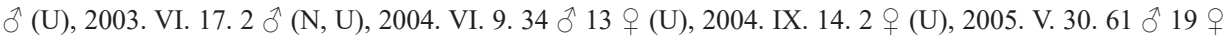

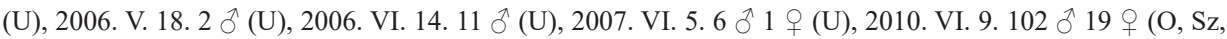
U), 2011. V. 19. 5 đ(O, U), 2016. VI. 1.1 (GÁ, M, U); Pécs, Nagypostavölgy 2017. VI. 1-2. 1 (GT); Vízvár, Dráva 1999. VII. 31. 7 đ 3 q (N, U), 2001. VI. 8. 2 đ (N, U), 2001. VII. 14. 3 (U, UP), 2001. VIII.

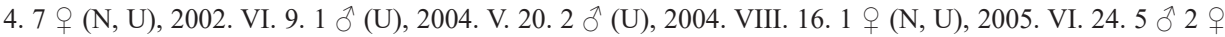
(U), 2006. V. 22. 1 क (U), 2006. VI. 13. 2 o (N, U), 2006. VIII. 17. 1 क (U).

Agrypnia pagetana Curtis, 1835 - Mike (N et al. 1985).

Agrypnia varia (Fabricius, 1793) - Barcs, erdészet (N 1985a); Barcs, erdészház (N 1985a); Barcs, halastó (N 1985a); Csesztreg-Kerkaújfalu (U 2004); Bélavár, Dráva (N \& U 1998); Belezna, Kakonyapuszta (N \& U 1998); „Darány“ (Ujhelyi 1981a); Darány, Kuti-őrház (N \& U 1998); Darány, Nagyberek (N 1985a, N \& U 1995, 1998); Drávaszentes, Ferenctelep (N \& U 1998); Drávasztára (N \& U 1998); Iharos, Ágneslak (N et al. 1985); „Középrigóc“ (Ujhelyi 1981a); Örtilos, Dráva (N \& U 1995); Patosfa (N \& U 1990); Pécs, Deindol (U \& N 2006); Siklós-Máriagyüd (N 2000); Tótújfalu, Dráva (N \& U 1998); Vízvár, Dráva (N \& U 1995); Zákány (N \& U 1998); Zalabaksa (U 2004) - Barcs, Kis-bók 1999. VIII. 5.3 đ̋ (U); Bélavár, Dráva 2002. VI. 18. 1 đึ (N, U); Darány, Nagyberek 2000. VI. 6. 1 đ (N, U); Drávasztára 1999. VIII. 9.1 đ(U); Gyékényes, Lankóci-e. 2004. VI. 9.1 \& (U); Örtilos, Dráva 2001. VI. 16. 1 ô (U), 2007. VI. 15.1 q (U); Pécs, Deindol 2018. VIII. 31. $1 \hat{\jmath}(\mathrm{U})$.

Phryganea bipunctata Retzius, 1783 - Alsószenterzsébet (U 2004); Bélavár, Ó-Dráva (U 2005).

Phryganea grandis Linnaeus, 1758 - Alsószenterzsébet (U 2004); Babócsa, ártér (N \& U 1998); Bakonya, Erdészház ( $\mathrm{N}$ et al. 1985); Barcs, Csikota (N 1985a); Barcs, Dráva-part (N \& U 1998); Barcs, erdészház (N 1985a); Barcs, Kisbók (N \& U 1998); Barcs, Rinya-Ó-Dráva (N \& U 1998); Barcs, szakiskola (N \& U 1998); Bélavár, Lókai-mezö (N \& U 1998); Bükkösd, Korpád, Sormás-v. (N et al. 1985); Csarnóta (N 2000); Csertő (N \& U 1990); Csesztreg-Kerkaújfalu (U 2004); Csörnyefölde (N et al. 1985); Darány, Kuti örház (N 1985a); Darány, temető (N 1985a); Diósviszló (N 2000); Drávapalkonya (N \& U 1995, 1998); Drávaszentes, Ferenctelep (N \& U 1998); Gyékényes, Lankóci-e. (N \& U 1998); Iharos, Ágneslak (N et al. 1985); Kisdobsza (N et al. 1985); Kisszentmárton, Majláthpuszta (N \& U 1995); Komlósd (N et al. 1985); Magyarszombatfa (U 


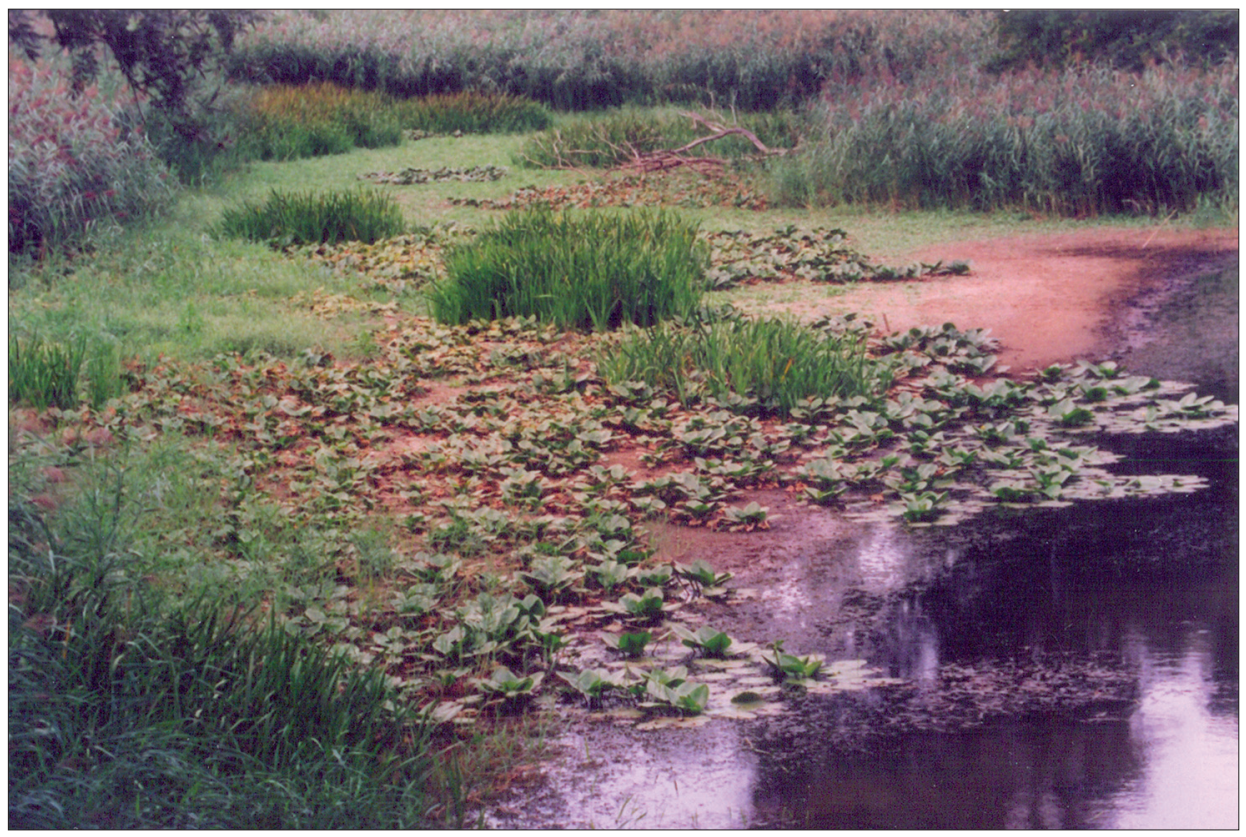

9. ábra: A Mura levágott holtága Murarátkánál, alacsony vízállásnál

Fig. 9: Oxbow lake of Mura river with low water level at Murarátka

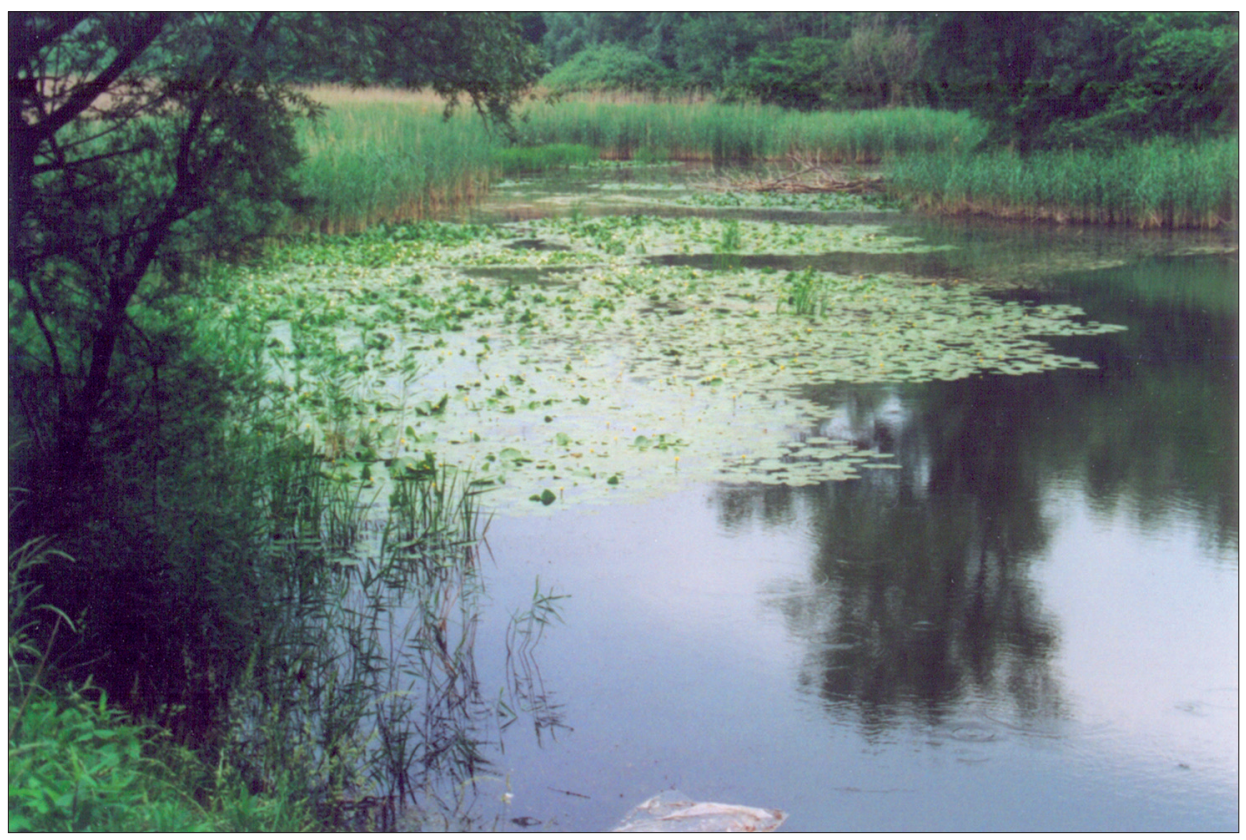

10. ábra: A Mura levágott holtága Murarátkánál, magas vízállásnál

Fig. 10: Oxbow lake of Mura river with high water level at Murarátka 


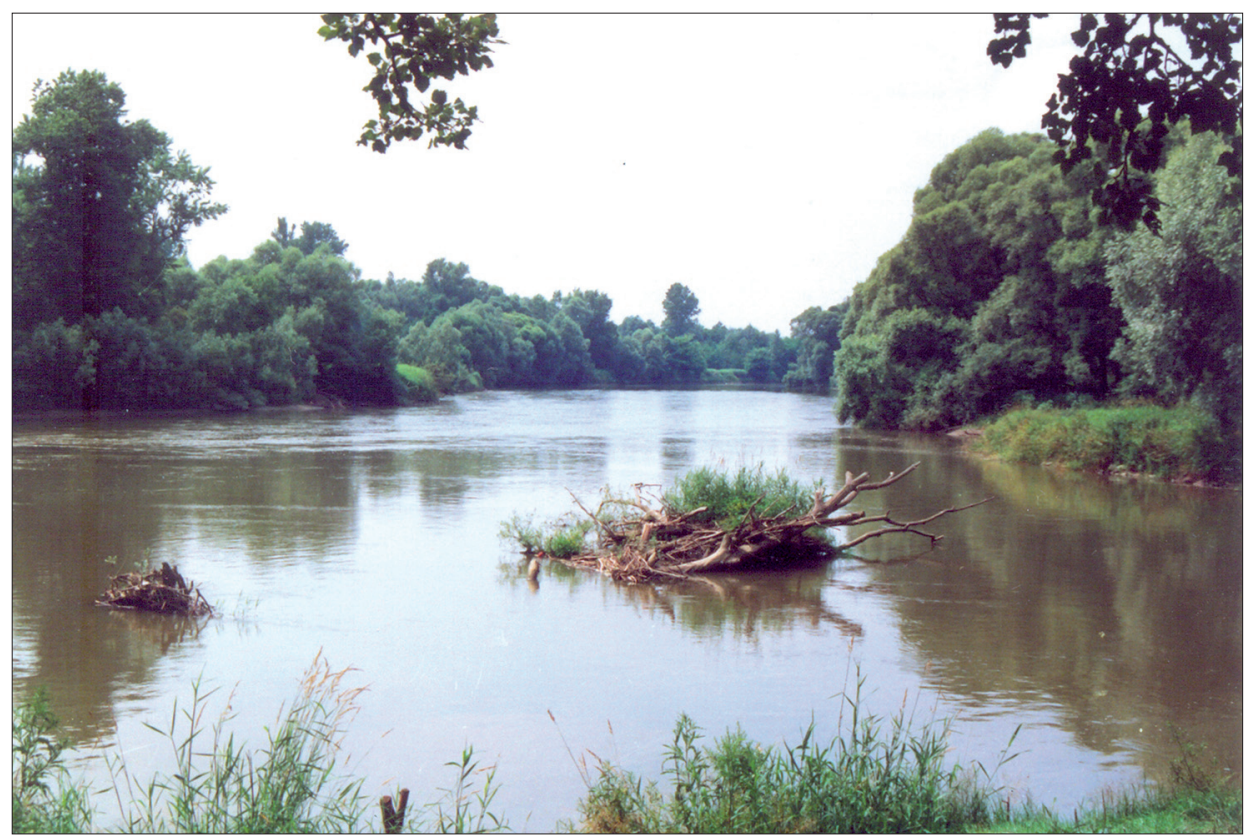

11. ábra: A Mura Muraszemenyénél

Fig. 11: Mura river at Muraszemenye

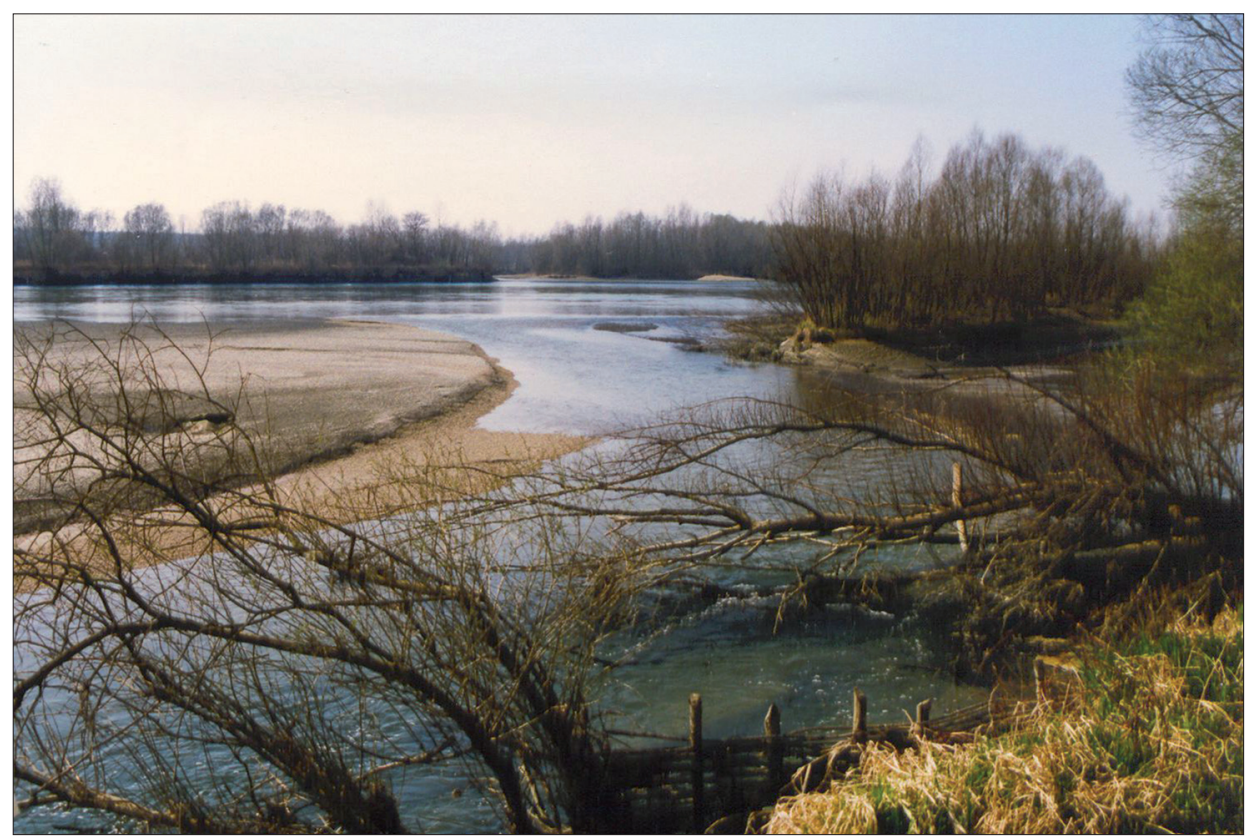

12. ábra: Épülő kavicszátonyok a Dráván, Vízvárnál

Fig. 12: Building gravel shoals in Dráva river, near Vízvár 
\& N 1992a); Örtilos, Dráva (N \& U 1995); Péterhida (N \& U 1998); Rédics, Kebele-p. (U 2004); Siklós, Csukma-h. (N 2000); Somogyapáti (N \& U 1990); Somogyudvarhely, Dombó-csat. (N \& U 1998); Szentborbás (U \& N 1992b); Szentlőrinc (N \& U 1990); Tormafölde (N et al. 1985); Tótújfalu, Dráva (N \& U 1998); Vízvár, Dráva (N \& U 1995) - Bakonya, Nagy-Rege 2017. VIII. 25. 1 q (GT, U); Barcs, Kis-bók 1999. VIII.

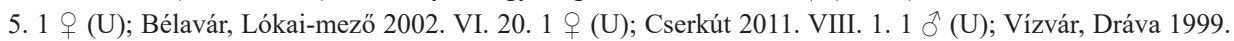

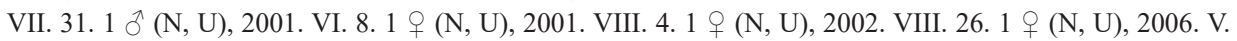
22. $1 \hat{\jmath}(\mathrm{U}), 2006$. VIII. 17. $1 \lesssim(\mathrm{U}), 2016$. V. 28. $1 \lesssim$ (GÁ, U).

Oligotricha striata (Linnaeus, 1758) - Magyarszombatfa (U \& N 1992a).

Hagenella clathrata (Kolenati, 1848) - Barcs, erdészház (N 1985a); Homokszentgyörgy (N \& U 1988); Kisdobsza (N et al. 1985, N \& U 1988); Magyarszombatfa (U \& N 1992a); Pellérd (N et al. 1985); Somogyudvarhely, Dombó-csat. (N \& U 1998); Szava (N 2000); Szentlőrinc (N et al. 1985) - Gyékényes,

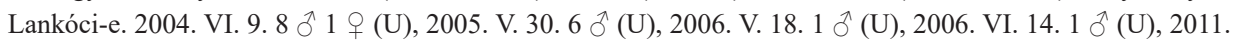
V. $19.1 \lesssim(\mathrm{O}, \mathrm{U})$.

Oligostomis reticulata (Linnaeus, 1761) - Babarcszőlős (N 2000); Hegyszentmárton (N 2000); Komlósd (N \& U 1998); Örtilos, Új-Zrínyi-vár (N \& U 1998) - Bélavár, Lókai-mező 2000. IV. 13. 4 đ̋ (U), 2002. IV. 15. $4 \lesssim 1$ (U), 2003. IV. 22. 1 ઈ 1 (U), 2004. IV. 22. 15 え 2 (U); Komlósd 2003. IV. 22.1 (U).

\section{Brachycentridae}

Brachycentrus subnubilus Curtis, 1834 - Barcs, Dráva-part (N \& U 1998); Barcs, Szilonics-p. (N \& U 1998); Bélavár, Dráva (N \& U 1998); Belezna, Mura (U 2004); Dobri (U 2004); Csarnóta (N 2000); Drávapalkonya (N \& U 1995, 1998); Drávasztára (N \& U 1995, 1998); Hirics, Dráva (N \& U 1998); Kerkaszentkirály, Kerka (U 2004); Kerkaszentmihály-Margitmajor, Lendva (U 2004); Kisdobsza (N et al. 1985, N \& U 1988); Muraszemenye (U 2004); Örtilos, ártér (N \& U 1998); Örtilos, Dráva (N \& U 1998); Szentlörinc (N \& U 1990); Tótszerdahely (U 2004); Tótújfalu, Dráva (N \& U 1998); Vejti, Dráva (N \& U 1995, 1998); Vízvár, Dráva (N \& U 1995, 1998); Zaláta, Adravica (N \& U 1998) - Barcs, Dráva 2000. IV. 13.3 §ै

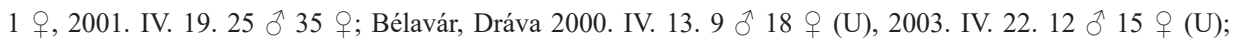

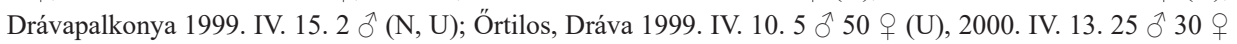

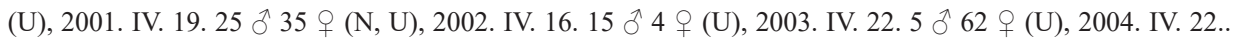
45 万 5 (U), 2005. IV. 29. 1 q (U); Somogyudvarhely 2000. IV. 13. 4 đ 2 (U); Szentborbás 2001. IV. 19.

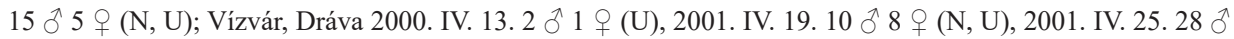

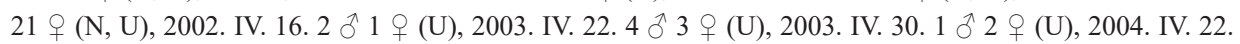
$5 \curvearrowright 5$ 元).

Micrasema setiferum (Pictet, 1834) - Barcs, halastó (N 1985a, 1985b).

\section{Limnephilidae}

Ironoquia dubia (Stephens, 1837) - Almamellék, Sas-rét (N \& U 1990); Barcs, Csikota (N 1985a); Barcs, erdészet (N 1985a); Barcs, halastó (N 1985a); Böhönye (N \& U 1992); Bükkösd, Korpád, Sormás-v. (N et al. 1985); Csurgó (N \& U 1998); Darány, Nagyberek (N \& U 1995); Kisdobsza (N et al. 1985, N \& U 1988); „Középrigóc“(Ujhelyi 1981a); Magyarszombatfa (U \& N 1992a); Pécs, Éger-völgy (N et al. 1985); Szentlőrinc (N \& U 1990).

Limnephilus affinis Curtis, 1834 - Barcs, erdészet (N 1985a); Barcs, erdészház (N 1985a); Barcs, halastó (N 1985a); Barcs, Rinya-Ó-Dráva (N \& U 1998); Barcs, szakiskola (N \& U 1998); Böhönye (N \& U 1992); Bükkösd, Korpád, Sormás-v. (N et al. 1985); Cserkút (N et al. 1985); Csertő (N \& U 1990); „Darány“ (Ujhelyi 1981a); Darány, Kuti őrház (N 1985a, N \& U 1998); Darány, Nagyberek (N 1985a, N \& U 1995, 1998); Darány, Szürühely-folyás (N 1985a); Drávasztára (N \& U 1995, 1998); Gilvánfa, erdészház (N et al. 1985); Hedrehely ( $\mathrm{N}$ et al. 1985); Homokszentgyörgy (N \& U 1988); Kisdobsza ( $\mathrm{N}$ et al. 1985, N \& U 1988); „Középrigóc“(Ujhelyi 1981a); Mike (N et al. 1985); Magyarszombatfa (U \& N 1992a); Matty, Keselyősfapuszta (N \& U 1998); Örtilos, Dráva (N \& U 1995); Pécs, Deindol (U \& N 2006); Pécs, Dömörkapu (U \& N 2006); Pécs, Misina (U \& N 2006); Siklós, Göntér (N 2000); Siklós-Máriagyüd (N 2000); Somogyudvarhely (N et al. 1985); Szentborbás (U \& N 1992b); Szentlőrinc (N \& U 1990); Vízvár, Dráva (N \& U 1995) - Bélavár, 


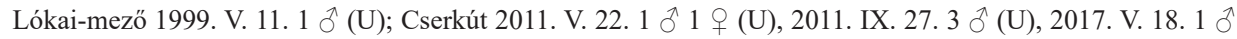
1 (GT, U); Drávasztára 2015. X. 19. 2 \& (GÁ, M); Gyékényes, Lankóci-e. 2006. V. 18. 1 đ 1 q (U), 2006.

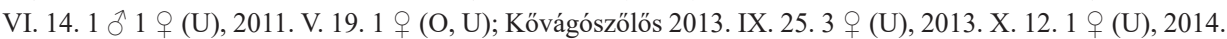
V. 9.1 (U), 2014. V. 21. 1 (U); Nagyharsány 2001. X. 10. 2 q (U); Örtilos, Dráva 2000. X. 31.2 \ 2 \%

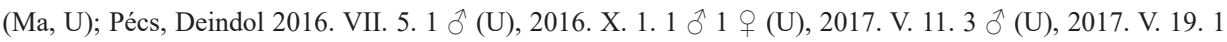

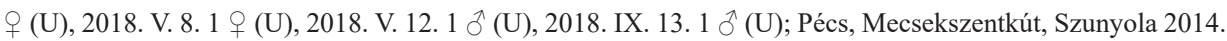

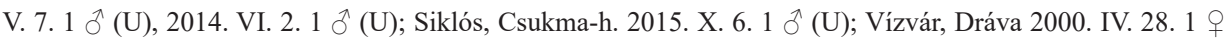

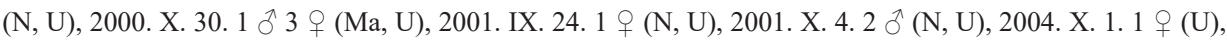
2006. V. 22. 1 q (U).

Limnephilus auricula Curtis, 1834 - Almamellék, Sas-rét (N \& U 1990); Babócsa, ártér (N \& U 1998); Bakonya, Erdészház (N et al. 1985); Barcs, Csikota (N 1985a); Barcs, halastó (N 1985a); Barcs, Rinya-ÓDráva (N \& U 1998); Barcs, szakiskola (N \& U 1998); Böhönye (N \& U 1992); Csarnóta (N 2000); Cserkút (N et al. 1985); „Darány“ (Ujhelyi 1981a); Darány, Kuti őrház (N 1985a); Darány, Nagyberek (N \& U 1995); Drávapalkonya (N \& U 1995); Drávasztára (N \& U 1998); Kemse, Háromfa (N \& U 1995, 1998); Kisdobsza (N et al. 1985, N \& U 1988); Kisszentmárton, Majláthpuszta (N \& U 1995); Komlósd (N et al. 1985); „Középrigóc“ (Ujhelyi 1981a); Magyarszombatfa (U \& N 1992a); Matty, Keselyősfapuszta (N \& U 1998); Örtilos, Dráva (N \& U 1995); Pécs, Éger-völgy (N et al. 1985); Pécs, Deindol (U \& N 2006); Pécs, Dömörkapu (U \& N 2006); Pécs, város (U \& N 2006); Potony, Lugi-erdő (N \& U 1995); Siklós, Göntér (N 2000); Somogyudvarhely (N et al. 1985); Szentlőrinc (N \& U 1990); Vejti, Dráva (N \& U 1995); Vízvár, Dráva (N \& U 1995, 1998) - Drávasztára 1999. X. 12. 1 đ 1 q (U); Gyékényes, Lankóci-e. 2002. V. 2.1 đ (U), 2005. V. 30. 1 §ิ 3 ㅇ (U), 2006. V. 18. 2 ㅇ (U); Ibafa, Gyürüfü 2008. X. 11. 1 † (U); Kerkaszentkirály, Kerka 2010.

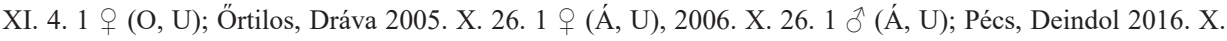
25. 1 q (U), 2018. V. 12.1 (U), 2018. V. 4.1 (U); Pécs, Nagypostavölgy 2018. V. 1-13. 1 q (GT); Siklós,

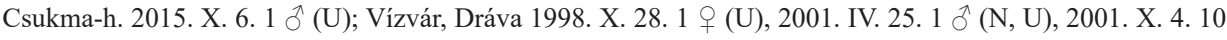

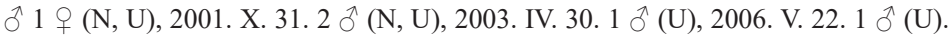

Limnephilus bipunctatus Curtis, 1834 - Almamellék, Sas-rét (N \& U 1990); Babócsa, ártér (N \& U 1998); Bakonya, Erdészház ( $\mathrm{N}$ et al. 1985); Barcs, Csikota (N 1985a); Barcs, szakiskola (N \& U 1998); Böhönye (N \& U 1992); Bükkösd, Korpád, Sormás-v. (N et al. 1985); Cserkút ( $\mathrm{N}$ et al. 1985); Darány, Nagyberek (N 1985a); Gilvánfa, erdészház ( $\mathrm{N}$ et al. 1985); Homokszentgyörgy (N \& U 1988); Kisdobsza (N et al. 1985, N \& U 1988); Magyarszombatfa (U \& N 1992a); Matty, Keselyősfapuszta (N \& U 1998); Pécs, Deindol (U \& N 2006); Pécs, Dömörkapu (U \& N 2006); Pécs, Misina (U \& N 2006); Szentborbás (U \& N 1992b, N \& U 1998); Vízvár, Dráva (N \& U 1995) - Gyékényes, Lankóci-e. 2002. V. 2.1 \& (U); Siklós-Máriagyűd 2006. X. 13. 1 ○ (U).

Limnephilus decipiens (Kolenati, 1848) - Barcs, Csikota (N 1985a); Böhönye (N \& U 1992); Gilvánfa, erdészház (N et al. 1985); Kisharsány (N 2000); Komlósd (N et al. 1985); Örtilos, Dráva (N \& U 1995); Somogyudvarhely (N et al. 1985) - Bakonya, Nagy-Rege 2017. VI. 12.1 đ̊ (U); Pécs, Deindol 2018. V. 8. 1

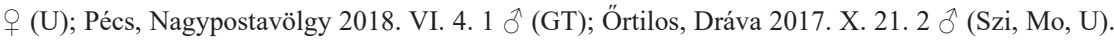

Limnephilus elegans Curtis, 1834 - Magyarszombatfa (U \& N 1992b).

Limnephilus extricatus McLachlan, 1865 - Almamellék, Sas-rét (N \& U 1990); Barcs, halastó (N 1985a); Böhönye (N \& U 1992); Csesztreg-Kerkaújfalu (U 2004); Darány, Kuti-őrház (N \& U 1998); Homokszentgyörgy (N \& U 1988); Magyarszombatfa (U \& N 1992a); Mike (N et al. 1985); Pécs, Deindol (U \& N 2006).

Limnephilus flavicornis (Fabricius, 1787) - Almamellék, Sas-rét (N \& U 1990); Babócsa, ártér (N \& U 1998); Bakonya, Erdészház (N et al. 1985); Barcs, Csikota (N 1985a); Barcs, halastó (N 1985a, N \& U 1995); Barcs, Rinya-Ó-Dráva (N \& U 1998); Barcs, szakiskola (N \& U 1998); Barcs, Szilonics-p. (N \& U 1998); Bélavár, Dráva (N \& U 1998); Bélavár, Kerék-hegy (N \& U 1998); Bélavár, Lókai-mező (N \& U 1998); Belezna, Kakonyapuszta (N \& U 1998); Berzence, Dombó-csat. (N \& U 1998); Böhönye (N \& U 1992); Cserkút (N et al. 1985); Csertő (N \& U 1990); „Darány“ (Ujhelyi 1981a); Darány, Kuti-őrház (N \& U 1998); Darány, Nagyberek (N 1985a, N \& U 1995, 1998); Darány, Szürühely-folyás (N 1985a); Diósviszló (N 2000); Drávapalkonya (N \& U 1995); Drávasztára (N \& U 1995, 1998); Gilvánfa, erdészház (N et al. 1985); Gyékényes, Lankóci-e. (N \& U 1998); Hedrehely (N et al. 1985); Homokszentgyörgy (N \& U 1988); 
Kisdobsza (N et al. 1985, N \& U 1988); Kisharsány (N 2000); Kisszentmárton, Majláthpuszta (N \& U 1995); Komlósd (N et al. 1985); „Középrigóc“ (Ujhelyi 1981a); Magyarszombatfa (U \& N 1992a); Matty, Keselyősfapuszta (N \& U 1998); Mike (N et al. 1985); Örtilos, Dráva (N \& U 1995); Pécs, Deindol (U \& N 2006); Potony, Lugi-erdő (N \& U 1995); Siklós, Csukma-h. (N 2000); Siklós, Göntér (N 2000); SiklósMáriagyüd (N 2000); Somogyudvarhely (N et al. 1985); Somogyudvarhely, Dombó-csat. (N \& U 1998); Szentborbás (U \& N 1992b, N \& U 1998); Tótújfalu, Dráva (N \& U 1998); Vejti, Dráva (N \& U 1995, 1998); Vízvár, Dráva (N \& U 1995) - Bélavár, Dráva 2002. X. 17. 2 \& (N, U); Cserkút 2011. V. 25. 1 q (U), 2011. IX. 28. 1 đ 1 q (U); Darány, Nagyberek 1998. VI. 12. 1 q (U), 1998. IX. 25.3 đ 4 q (N, U), 1999. V. 19. 3

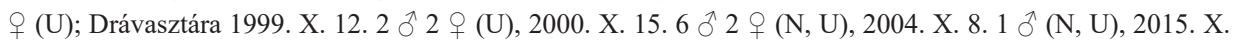

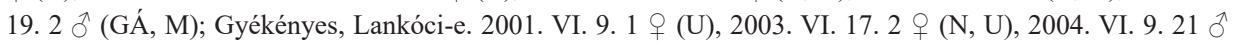

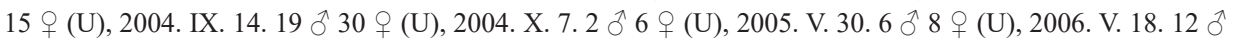

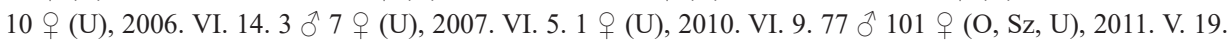

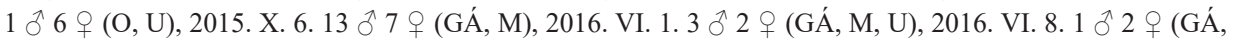
M, U); Kerkaszentkirály, Kerka 2010. XI. 4. 1 † (O, U); Kővágótöttös, Cserma-h. 2018. V. 31. 1 § (GT); Nagyharsány 2001. X. 10. 1 q (U); Örtilos, Dráva 2000. X. 31. 2 đ (Ma, U), 2006. X. 26. 1 đ̊ (Á, U); Pécs,

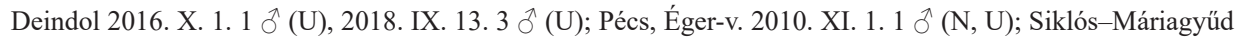

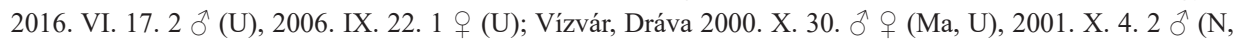

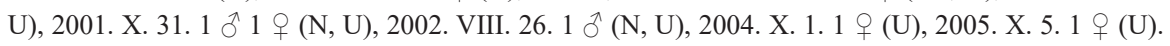

Limnephilus griseus (Linnaeus, 1758) - Bakonya, Erdészház (N et al. 1985); Barcs, Csikota (N 1985a); Barcs, erdészház (N 1985a); Barcs, halastó (N 1985a); Bélavár, Dráva (N \& U 1998); Böhönye (N \& U 1992); Bükkösd, Korpád, Sormás-v. (N et al. 1985); Cserkút (N et al. 1985); Darány, Kuti őrház (N 1985a); Darány, Nagyberek (N 1985a, N \& U 1995); Darány, Szürühely-folyás (N 1985a); Gilvánfa, erdészház (N et al. 1985); Kisdobsza (N et al. 1985, N \& U 1988); „Középrigóc“ (Ujhelyi 1981a); Őrtilos, Dráva (N \& U 1995); Pécs, Deindol (U \& N 2006); Pécs, Dömörkapu (U \& N 2006); Siklós, Csukma-h. (N 2000); Siklós-Máriagyüd (N 2000); Szulok (N et al. 1985); Magyarszombatfa (U \& N 1992a); Szentborbás (U \& N 1992b); Vízvár, Dráva (N \& U 1995, 1998 - Bakonya, Nagy-Rege 2017. X. 5. 2 § (GT, U); Cserkút 2011. IX. 27.1 đ(U), 2011. IX.

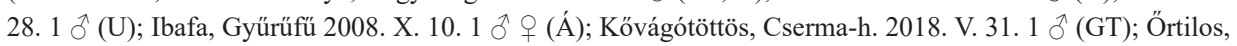

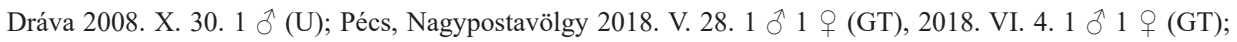

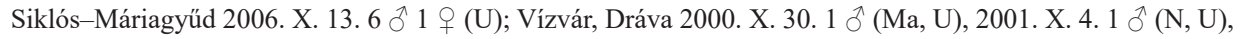
2001. X. 31. 1 ふै (N, U).

Limnephilus hirsutus (Pictet, 1834) - Almamellék, Sas-rét (N \& U 1990); Barcs, halastó (N 1985a); Cserkút ( $N$ et al. 1985); Csertő (N \& U 1990); Kisdobsza ( $N$ et al. 1985, $N$ et al. 1988); Magyarszombatfa (U \& N 1992a); Pécs, Deindol (U \& N 2006); Pécs, Tubes (N et al. 1985).

Limnephilus ignavus McLachlan, 1865 - Almamellék, Sas-rét (N \& U 1990); Barcs, halastó (N 1985a, N \& U 1995); Böhönye (N \& U 1992); Bükkösd, Korpád, Sormás-v. (N et al. 1985); Csarnóta (N 2000); Cserkút (N et al. 1985); Kisdobsza (N \& U 1988); Kisharsány (N 2000); Magyarszombatfa (U \& N 1992a); Pécs, Deindol (U \& N 2006); Siklós, Csukma-h. (N 2000); Siklós-Máriagyüd (N 2000) - Bakonya, Sás-v. 2017. VII.

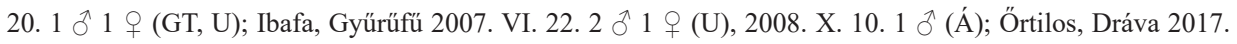

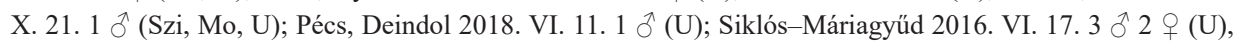
2016. VII. 20. 1 ð (U, USz), 2006. IX. 14. 1 † (U); Szava, Szőlőhegy 2014. VI. 19. 1 \& (Ö, U).

Limnephilus incisus Curtis, 1834 (Colpotaulius i.) - Bélavár, Dráva (N \& U 1998); Böhönye (N \& U 1992); Csertő (N \& U 1990); Drávasztára (N \& U 1995, 1998); Gordisa, Mattyi-tó (N \& U 1995); Hedrehely (N et al. 1985); Kisdobsza (N \& U 1988); Komlósd (N \& U 1998); Magyarszombatfa (U \& N 1992a); Pécs, Deindol (U \& N 2006); Pellérd, halastavak (U \& N 2006); Szentlőrinc (N \& U 1990); Szulimán (N \& U 1990); Vejti, Dráva (N \& U 1995) - Almamellék, Almás-p. 1998. VII. 19. 1 (U); Bakonya, Nagy-Rege 2017. VI. 12. 1 ㅇ

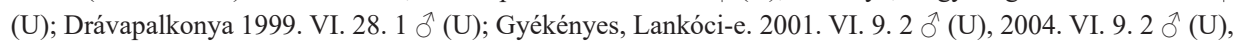
2005. V. 30. 1 † (U); Pécs, Nagypostavölgy 2017. VII. 10-18. 1 đ(GT).

Limnephilus lunatus Curtis, 1834 - Almamellék, Sas-rét (N \& U 1990); Alsószenterzsébet (U 2004); Babócsa, ártér (N \& U 1998); Barcs, Csikota (N 1985a); Barcs, halastó (N 1985a); Barcs, halastó I. (N \& U 1998); Barcs, Rinya-Ó-Dráva (N \& U 1998); Barcs, szakiskola (N \& U 1998); Bélavár, Dráva (N \& U 1998); 
Bélavár, Lókai-mezö (N \& U 1998); Böhönye (N \& U 1992); Csarnóta (N 2000); Cserkút (N et al. 1985); Csesztreg-Kerkaújfalu (U 2004); Darány, Szürühely-folyás (N 1985a); „Darány“ (Ujhelyi 1981a); Drávapalkonya (N \& U 1995); Drávaszentes, Ferenctelep (N \& U 1998); Gilvánfa, erdészház (N et al. 1985); Hedrehely (N et al. 1985); Kercaszomor (U 2004); Kerkaszentkirály, Kerka (U 2004); Kisdobsza (N et al. 1985, N \& U 1988); Kisharsány (N 2000); Kisszentmárton, Majláthpuszta (N \& U 1995); Komlósd (N et al. 1985); „Középrigóc“ (Ujhelyi 1981a); Lenti, Bárszentmihályfa (U 2004); Magyarföld (U 2004); Magyarszombatfa (U \& N 1992a); Mike (N et al. 1985); Őrtilos, Dráva (N \& U 1995); Pécs, Deindol (U \& N 2006); Pécs, Dömörkapu ( $\mathrm{N}$ et al. 1985); Pécs, Éger-völgy ( $\mathrm{N}$ et al. 1985); Pécs, Tubes ( $\mathrm{N}$ et al. 1985); Pécs, város (U \& N 2006); Siklós, Csukma-h. (N 2000); Siklós-Máriagyűd (N 2000); Somogyudvarhely (N et al. 1985, N \& U 1998); Szentborbás (U \& N 1992b, N \& U 1998); Szentlászló (N \& U 1990); Szentlőrinc (N \& U 1990); Tormafölde (N et al. 1985); Tótújfalu, Dráva (N \& U 1998); Vejti, Dráva (N \& U 1995, 1998); Vízvár, Dráva (N \& U 1998) - Bakonya, Nagy-Rege 2017. V. 28. 1 đ 1 o (U), 2017. VI. 12.1 đ (U), 2017. X. 5. 1

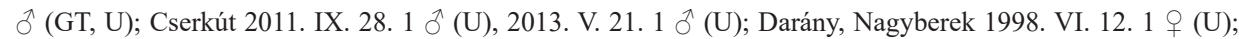

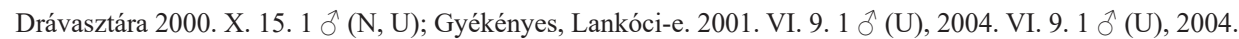

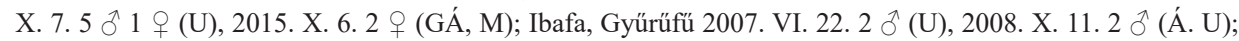

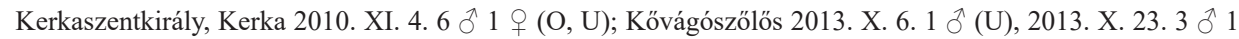

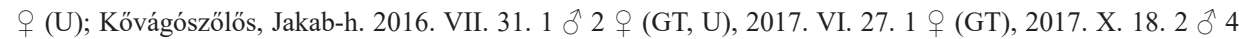

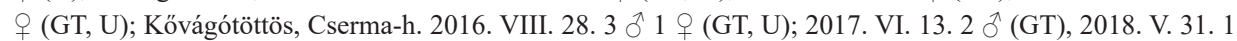

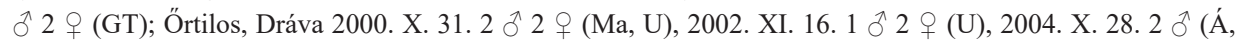
U), 2010. XI. 3.1 (O, U), 2017. X. 21. 2 đ (Szi, Mo, U); Pécs, Deindol 2011. V. 30. 1 q (U), 2015. XI. 9.

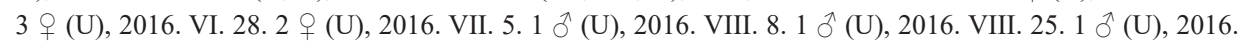
IX. 4. $1 \lesssim(U)$, 2016. IX. 7. $1 \lesssim(U)$, 2016. X. $1.2 \lesssim(U), 2016$. XI. $2.2 \lesssim(U), 2017$. VI. $4.2 \lesssim 1$ (U),

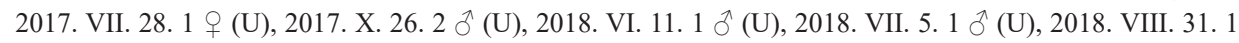

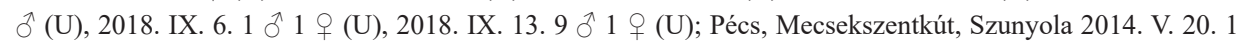

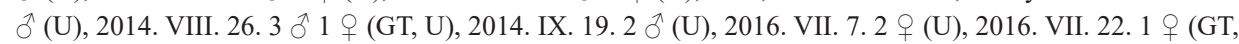

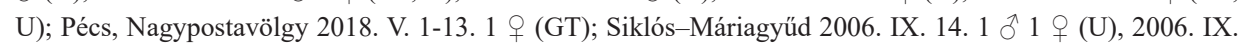
22. 1 đ(U), 2006. X. 13. 1 q (U), 2015. VI. 13. 1 đ(U); Somogyudvarhely 2000. V. 4.1 q (U); Vízvár, Dráva 2001. X. 4. $2 \precsim$ (N, U), 2004. X. $1.4 \lesssim 1$ (U), 2004. XI. 2.1 (U), 2006. V. 22.1 (U), 2009. XI. 16.1 ô (U), 2015. XI. 10. 1 ㅇ (GÁ, M).

Limnephilus rhombicus (Linnaeus, 1758) - Almamellék, Sas-rét (N \& U 1990); Alsószenterzsébet (U 2004); Babócsa, Rinya (N \& U 1995); Bakonya, Erdészház (N et al. 1985); Barcs, halastó (N 1985a); Böhönye (N \& U 1992); Bükkösd, Korpád, Sormás-v. (N et al. 1985); Csarnóta (N 2000); Csesztreg-Kerkaújfalu (U 2004); Darány, Nagyberek (N 1985a); „Darány“ (Ujhelyi 1981a); Kisdobsza (N et al. 1985, N \& U 1988); Komlósd (N et al. 1985); Magyarszombatfa (U \& N 1992a); Örtilos, Dráva (N \& U 1995); Pécs, Deindol (U \& N 2006); Péterhida (N \& U 1998); Siklós, Csukma-h. (N 2000); Siklós-Máriagyűd (N 2000); Somogyudvarhely (N et al. 1985); Szentlőrinc (N \& U 1990); Szulimán (N \& U 1990); Vízvár, Dráva (N \& U 1995) - Cserkút 2011.

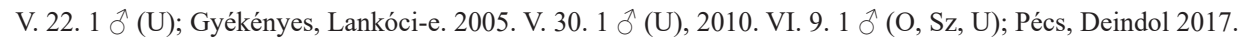

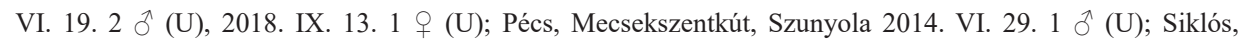
Csukma-h. 2015. VI. 13. 1 $\precsim(\mathrm{U})$.

Limnephilus sparsus Curtis, 1834 - Abaliget, Nyáras-v. (U \& N 2006); Almamellék, Sasrét (N et al. 1985, N \& U 1990); Bakonya, Erdészház (N et al. 1985); Böhönye (N \& U 1992); Bükkösd, Korpád, Sormás-v. (N et al. 1985); Cserkút ( $\mathrm{N}$ et al. 1985); Darány, Kuti őrház (N 1985a); Hetvehely, Nyáras-v. (N et al. 1985); Homokszentgyörgy (N \& U 1988); Kisdobsza (N et al. 1985); Magyarszombatfa (U \& N 1992a); Patosfa (N \& U 1990); Pécs, Deindol (U \& N 2006) - Ibafa, Gyürüfü 2007. VI. 22. 1 ð (U), 2008. X. 10. 1 § (Á), 2008. X. 11.1 ( 1 (U).

Limnephilus stigma Curtis, 1834 - Gyékényes, Lankóci-e. (N \& U 1998, U 2005) - Gyékényes, Lankóci-e.

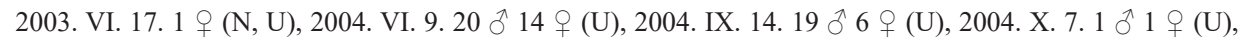

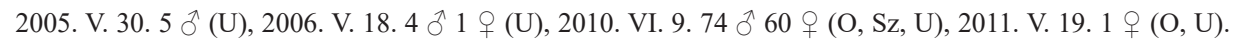

Limnephilus subcentralis Brauer, 1857 - Böhönye (N \& U 1992); Darány, Nagyberek (N 1992a, N \& U 1995). 
Limnephilus vittatus (Fabricius, 1798) - Almamellék, Sas-rét (N \& U 1990); Babócsa, ártér (N \& U 1998); Barcs, Csikota (N 1985a); Barcs, erdészház (N 1985a); Barcs, halastó (N 1985a); Barcs, szakiskola (N \& U 1998); Böhönye (N \& U 1992); Cserkút (N et al. 1985); Darány, Kuti őrház (N 1985a); Darány, Nagyberek (N 1985a, N \& U 1995); Darány, Szűrühely-folyás (N 1985a); Homokszentgyörgy (N \& U 1988); Kisdobsza (N et al. 1985, N \& U 1988); Kisszentmárton, Majláthpuszta (N \& U 1995); Komlósd ( $\mathrm{N}$ et al. 1985); Magyarszombatfa (U \& N 1992a); Matty, Keselyősfapuszta (N \& U 1998); Pécs, Deindol (U \& N 2006); Pécs, Dömörkapu (U \& N 2006); Pécs, Misina (N et al. 1985, U \& N 2006); Siklós, Göntér (N 2000); Szentborbás (U \& N 1992b); Szentlörinc (N \& U 1990); Vízvár, Dráva (N \& U 1998); Zaláta, rét (N \& U 1995) - Darány, Nagyberek 1999. V. 19. 1 § (U); Gyékényes, Lankóci-e. 2005. V. 30.1 † (U); Kerkaszentkirály, Kerka 2010. XI. 4. 1 đ (O, U); Nagyharsány 2001. X. 10. 1 đ (U); Örtilos, Dráva 2000. X. 31. 1 ㅇ (Ma, U); SiklósMáriagyüd 2006. X. 13. 1 đ̊ (U); Vízvár, Dráva 2001. X. 31.1 đ̊ 1 \& (N, U).

Limnephilus xanthodes Curtis, 1834 - Barcs, szakiskola (N \& U 1998); Kisdobsza (N et al. 1985).

Grammotaulius nigropunctatus (Retzius, 1783) - Abaliget, Nyáras-v. (N et al. 1985); Almamellék, Sasrét (N et al. 1985); Bakonya, Erdészház ( $\mathrm{N}$ et al. 1985); Barcs, Csikota (N 1985a); Barcs, erdészház ( $\mathrm{N}$ 1985a); Barcs, halastó (N 1985a, N \& U 1995); Barcs, Rinya-Ó-Dráva (N \& U 1998); Barcs, szakiskola (N \& U 1998); Barcs, Szilonics-p. (N \& U 1998); Bélavár, Dráva (N \& U 1998); Böhönye (N \& U 1992); Bükkösd, Korpád, Sormás-v. (N et al. 1985); Csarnóta (N 2000); Cserkút (N et al. 1985); Csertő (N \& U 1990); Darány, Kuti őrház (N 1985a); Darány, Nagyberek (N 1985a, N \& U 1995, 1998); Darány, Szürühely-folyás (N 1985a); Darány, temető (N 1985a); Diósviszló (N 2000); Gilvánfa, erdészház (N et al. 1985); Gyékényes, Lankóci-e. (N \& U 1998); Hedrehely ( $N$ et al. 1985); Homokszentgyörgy (N \& U 1988); Kemse, Háromfa (N \& U 1995); Kisdobsza (N et al. 1985, N \& U 1988); Kisszentmárton, Majláthpuszta (N \& U 1995); Komlósd (N et al. 1985); „Középrigóc“ (Ujhelyi 1981a); Magyarszombatfa (U \& N 1992a); Matty, Keselyősfapuszta (N \& U 1998); Pécs, Deindol (U \& N 2006); Pécs, Dömörkapu (U \& N 2006); Pécs, Kertváros (N et al. 1985); Pécs, Misina (U \& N 2006); Potony (N \& U 1998); Sellye (N et al. 1985); Siklós, Göntér (N 2000); SiklósMáriagyüd (N 2000); Somogyudvarhely (N et al. 1985); Szentborbás (U \& N 1992b); Szentlőrinc (N \& U 1990); Vejti, Dráva (N \& U 1995); Vízvár, Dráva (N \& U 1995) - Cserkút 2011. V. 2.2 q (U), 2011. V. 22.1 § (U), 2011. IX. 28. 1 đ (U); Darány, Nagyberek 1998. IX. 25. 1 † (N, U), 1999. V. 19. 1 † (U); Drávasztára 2015. X. 19. 1 q (GÁ, M); Gyékényes, Lankóci-e. 2001. IV. 29. 2 § 1 (U), 2002. V. 2.4 đ 3 (U), 2004. X. 7. 2 ภ 4 ㅇ (U), 2006. V. 18. 3 ㅇ (U), 2015. X. 6. 3 ㅇ (GÁ, M); Ibafa, Gyürüfü 2006. V. 20. 1 đ (Á); Kővágószőlős, Jakab-h. 2017. IV. 26. 1 † (GT, U); Örtilos, Dráva 2000. X. 31. 2 §ิ (Ma, U); Pécs, Deindol 2014. VI. $1.1 \delta(U), 2018$. V. 8. 1 §(U), 2018. V. 12. 1 q (U); Pécs, Mecsekszentkút, Szunyola 2014. VI. 2. 1 ô (U); Pécs, Nagypostavölgy 2017. VI. 15. 1 † (GT), 2017. VI. 26. 1 đ(GT); Siklós, Csukma-h. 2015. V.

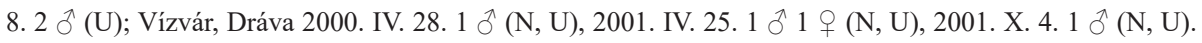

Glyphotaelius pellucidus (Retzius, 1783) - „Abaliget” (U \& N 2006); Abaliget, Nyáras-v. (U \& N 2006); Babócsa, ártér (N \& U 1998); Bakonya, Erdészház (N et al. 1985); Bakonya, Sás-v. (U \& N 2006); Barcs, erdészet (N 1985a); Barcs, erdészház (N 1985a); Barcs, halastó (N 1985a, N \& U 1988); Barcs, Rinya-ÓDráva (N \& U 1998); Barcs, szakiskola (N \& U 1998); Barcs, Szilonics-p. (N \& U 1998); Bélavár, Dráva (N \& U 1998); Bélavár, Kerék-hegy (N \& U 1998); Bélavár, Lókai-mező (N \& U 1998); Böhönye (N \& U 1992); Cserkút (N et al. 1985); Csesztreg-Kerkaújfalu (U 2004); „Darány“ (Ujhelyi 1981a); Darány, Kerek-tó (N 1985a); Darány, Kuti-őrház (N \& U 1998); Darány, Nagyberek (N 1985a, N \& U 1988, 1998); Darány, Szürühely-folyás (N 1985a); Darány, temető (N 1985a); Drávapalkonya (N \& U 1995); Drávasztára (N \& U 1998); Felsőszentmárton, Korcsina-csat. (N \& U 1998); Gyékényes, Lankóci-e. (N \& U 1998); Hedrehely (N et al. 1985); Hetvehely, Bükkösdi-v. (U \& N 2006); Hetvehely, Sás-v. (U \& N 2006); Homokszentgyörgy (N \& U 1988); Kemse, Háromfa (N \& U 1998); Kisdobsza (N et al. 1985, N \& U 1988); Kisszentmárton, Majláthpuszta (N \& U 1995); Komlósd (N et al. 1985); „Középrigóc“ (Ujhelyi 1981a); Magyarszombatfa (U \& N 1992a); Matty, Keselyősfapuszta (N \& U 1998); Muraszemenye (U 2004); Őrtilos, Dráva (N \& U 1995); Patosfa (N \& U 1990); Pécs, Deindol (U \& N 2006); Pécs, Éger-v. (U \& N 2006); Péterhida (N \& U 1998); Potony, Lugi-erdő (N \& U 1995, 1998); Siklós-Máriagyüd (N 2000); Somogyudvarhely, Dombó-csat. (N \& U 1998); Szava (N 2000); Szentborbás (U \& N 1992b); Tótújfalu, Dráva (N \& U 1998); Tótújfalu, Lugi-e. (N \& U 1998); Vejti, Dráva (N \& U 1995, 1998); Vízvár, Dráva (N \& U 1995, 1998); Zalabaksa (U 2004) - 


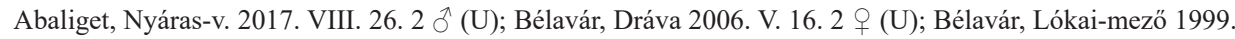

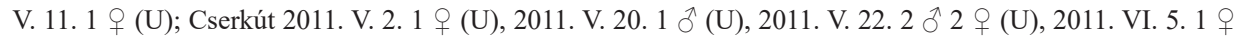
(U), 2011. IX. 27. 1 ㅇ (U), 2013. V. 18. 1 ㅇ (U), 2016. V. 23. 1 đ (U); Darány, Nagyberek 1998. VI. 12. 1 우 (U), 1998. IX. 25. 4 ๙ 1 ㅇ (N, U) 1999. IV. 30. 4 q (U), 1999. V. 19. 2 q (U); Drávaszentes, Ferenc-telep

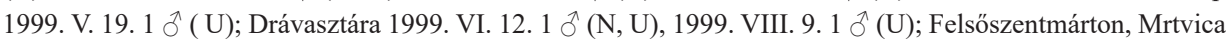
1999. VI. 20. 1 (U); Gyékényes, Lankóci-e. 2000. V. 28. 1 đ(N, U), 2001. IV. 29. 1 đ 1 (U), 2002. V. 2.

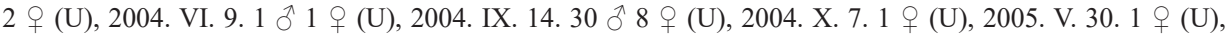

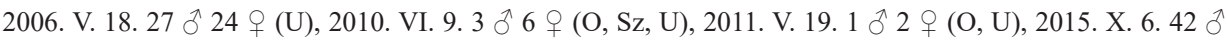
4 † (GÁ, M); Kercaszomor 2007. X. 14. 1 q (U); Kővágószőlős 2013. IX. 25. 1 † (U), 2014. V. 10. 1 q (U); Kővágószőlős, Jakab-h. 2017. IV. 26. 1 q (GT, U), 2017. VI. 27. 1 q (GT); Kővágótöttös, Cserma-h. 2016. VIII. 28. 1 đิ (GT, U), 2018. V. 31.1 9 (GT); Örtilos, Dráva 2004. X. 28. 1 đิ (Á, U); Pécs, Deindol 2015. IV.

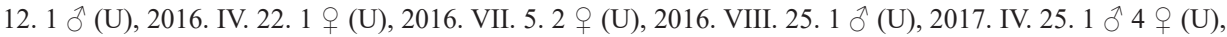

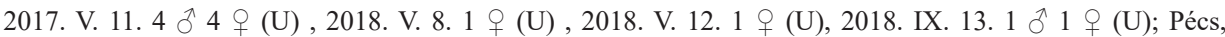
Mecsekszentkút, Szunyola 2014. V. 7. 1 † (U), 2014. VI. 22. 1 q (GT, U); Pécs, Nagypostavölgy 2017. VI. 1-2. 1 § (GT), 2017. VII. 20. 1 đ(GT); Siklós-Máriagyüd 2016. VI. 17.1 \& (U), 2016. VI. 21.1 (U), 2016. VI. 27. 1 (N, U), 2016. VII. 20. 1 đ 1 (U, USz); Siklós, Csukma-h. 2015. VI. 13. 1 q (U), 2015. VIII. 9. 3 q (GT, U); Vízvár, Dráva 1999. IX. 30. 1 đ(U), 2001. IV. 25. 1 q (N, U), 2001. IX. 24. 1 § (N, U), 2001. X. 4. $10 \lesssim 1$ (N, U), 2003. IV. 30. 1 q (U), 2004. V. 20. 2 q (U), 2004. IX. 12. 1 ^ 1 (N, U), 2006. V. 22. 2 ㅇ (U), 2015. IX. 16. 1 § 3 (GÁ, M, U).

Anabolia brevipennis (Curtis, 1834) (Phacopteryx b.) - Barcs, halastó (N \& U 1995); Böhönye (N \& U 1992); Gyékényes, Lankóci-e. (N \& U 1998); Kisdobsza (N 1986, N \& U 1988); Magyarszombatfa (U \& N 1992aa) - Bélavár, Lókai-mező 2004. VI. 18. 1 đ (U); Gyékényes, Lankóci-e. 2004. VI. 9.2 § 4 (U), 2004.

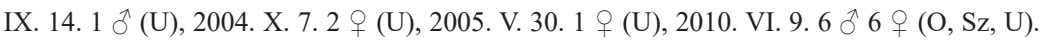

Anabolia furcata Brauer, 1857 - Alsószenterzsébet (U 2004); Babócsa, Rinya (N \& U 1998); Bélavár, Dráva (N \& U 1998); Berzence, Tekeres-berki-p. (N \& U 1998); Böhönye (N \& U 1992); Bükkösd, Korpád, Sormás-v. (N et al. 1985); Drávasztára (N \& U 1998); Felsőszentmárton, Korcsina-csat. (N \& U 1998); Helesfa (N et al. 1985); Hetvehely, Nyáras-v. (N et al. 1985); Kerkaszentkirály, Kerka (U 2004); Kisdobsza (N \& U 1988); Lenti, Bárszentmihályfa (U 2004); Magyarföld (U 2004); Magyarszombatfa (U \& N 1992a); Muraszemenye (U 2004); Nemesnép (U 2004); Örtilos, Dráva (N \& U 1995, 1998); Pécs, Éger-v. (U \& N 2006); Rédics, Kebele-p. (U 2004); Resznek, Szentgyörgyvölgyi-p. (U 2004); Somogyapáti (N \& U 1990); Somogyudvarhely, Dombó-csat. (N \& U 1998); Szentborbás (U \& N 1992b, N \& U 1998); Szentlászló (N et al. 1985, N \& U 1990); Szentlőrinc (N et al. 1985, N \& U 1990); Szulimán (N et al. 1985); Tormafölde (U 2004); Vásárosbéc (N et al. 1985); Vejti, Dráva (N \& U 1998); Vízvár, Dráva (N \& U 1995, 1998); Vízvár, Vízház (N \& U 1998); Zákány (N \& U 1998); Zalabaksa (U 2004) - Babócsa, Rinya 1999. V. 19. 3 đ̊ 1 (U);

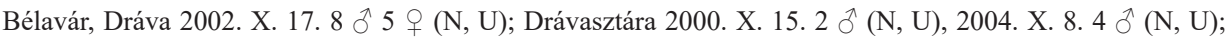
Gyékényes, Dombó-csat. 2004. X. 7. 1 đ 4 † (U); Kerkaszentkirály, Kerka 2010. XI. 4. 16 § 1 (O, U); Nagyatád, Hóka-malom 2004. X. 7. 1 đ 2 ㅇ (U); Örtilos, Dráva 2000. X. 31.6 đ 1 (Ma, U), 2002. XI. 16.

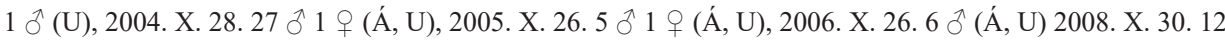

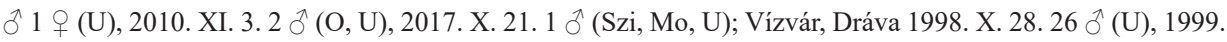

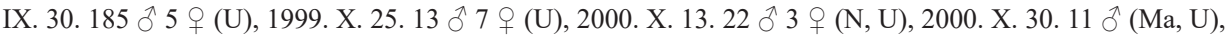

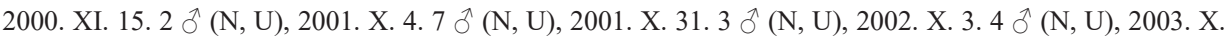
31. $9 \widehat{\delta}(\mathrm{U})$, 2004. X. 1. $21 \hat{\delta}(\mathrm{U}), 2004$. X. 26. $44 \hat{\jmath} 1$ q (U), 2004. XI. 2. 54 2 q (U), 2005. X. 5. 40

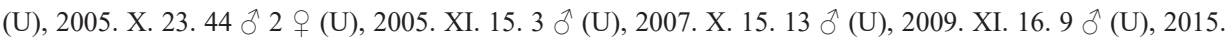
X. 28. 17 ઈิ (GÁ, M), 2015. XI. 10. 2 ô (GÁ, M).

Rhadicoleptus alpestris (Kolenati, 1848) - Darány, Nagyberek (N \& U 1995); Gyékényes, Lankóci-e. (N \& U 1998); Magyarszombatfa (U \& N 1992a); Szulimán (N \& U 1990).

Potamophylax luctuosus (Piller et Mitterpacher, 1783) - Drávasztára (N \& U 1998).

Potamophylax nigricornis (Pictet, 1834) - Abaliget, Nyáras-v. (U \& N 2006); Almamellék, Sas-rét (N \& U 1990); Bakonya, Sás-v. (U \& N 2006); Bükkösd, Korpád, Sormás-v. (N et al. 1985); Cserkút (N et al. 1985); Magyarszombatfa (U \& N 1992a); Pécs, Deindol (U \& N 2006); Pécs, Éger-völgy (N et al. 1985); Pécs, Tubes 
(N et al. 1985) - Abaliget, Nyáras-v. 2017. V. 29. 2 † (U), 2017. VI. 15.1 § 3 \& (U); Bakonya, Nagy-Rege

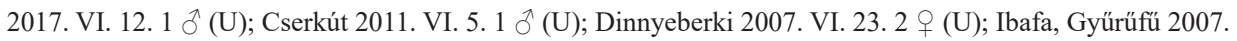
VI. 22. 1 đ 1 (U); Kővágószőlős 2014. V. 21. 1 đ 1 (U), 2014. V. 26.1 (U); Kővágótöttös, Cserma-hegy 2018. V. 31.1 đ (GT); Pécs, Mecsekszentkút, Szunyola 2014. VI. 2.1 đ(U); Pécs, Nagypostavölgy 2017. VI. 15. 1 ○ (GT).

Potamophylax rotundipennis (Brauer, 1857) - Alsószenterzsébet (U 2004); Barcs, szakiskola (N \& U 1998); Bélavár, Dráva (N \& U 1998); Belezna, Mura (N \& U 1998); Böhönye (N \& U 1992); Bükkösd, Korpád, Sormás-v. (N et al. 1985); Csertő (N \& U 1990); Dobri (U 2004); Hetvehely, Bükkösdi-v. (U \& N 2006); Kerkaszentkirály, Kerka (U 2004); Kisdobsza (N \& U 1988); Magyarszombatfa (U \& N 1992a); Örtilos, Dráva (N \& U 1995, 1998); Őrtilos, Új-Zrínyi-vár (N \& U 1998); Resznek, Szentgyörgyvölgyi-p. (U 2004); Szentgyörgyvölgy (U 2004); Szentlászló (N \& U 1990); Szulimán (N \& U 1990); Vízvár, Dráva (N \& U 1998)

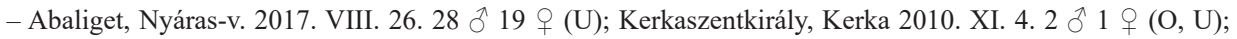
Örtilos, Dráva 2005. X. 26. 1 我, U), 2006. X. 26. 1 \& (Á, U); Vízvár, Dráva 1998. X. 28. 1 q (U), 1999.

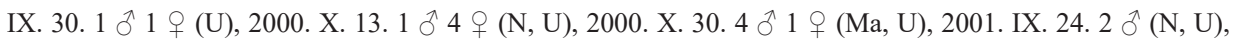

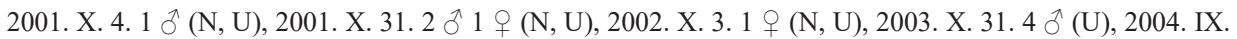

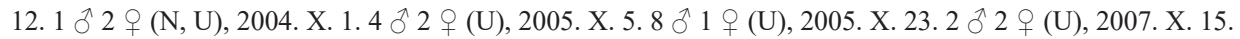

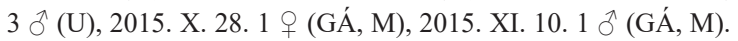

Halesus digitatus (Schrank, 1781) - Magyarszombatfa (U \& N 1992a).

Halesus radiatus (Curtis, 1834) - Muraszemenye (U 2004).

Halesus tesselatus (Rambur, 1842) - Barcs, szakiskola (N \& U 1998); Bélavár, Dráva (N \& U 1998); Belezna, Mura (N \& U 1998); Böhönye (N \& U 1992); Bükkösd, Gorica (N et al. 1985); Csurgó (N \& U 1998); Dobri (U 2004); Kerkaszentkirály, Kerka (U 2004); Kisdobsza (N \& U 1988); „Középrigóc“ (Ujhelyi 1981a); Örtilos, Dráva (N \& U 1995, 1998); Szentlőrinc (N \& U 1990); Szentborbás (U \& N 1992b, N \& U 1998); Szentgyörgyvölgy (U 2004); Vízvár, Dráva (N \& U 1995, 1998); Zákány (N \& U 1998); Zalabaksa (U 2004)

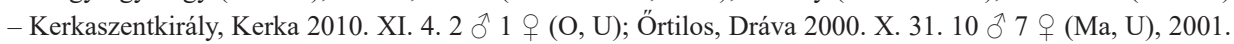

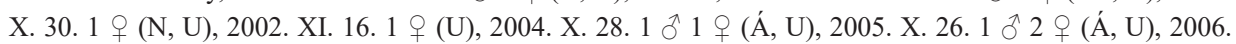

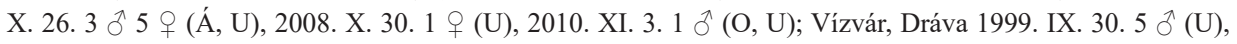

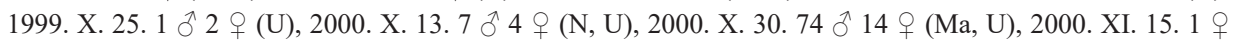

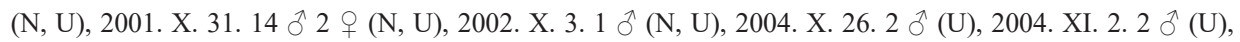

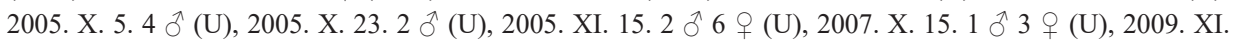
16. 8 ○े 6 (U), 2015. X. 28. 1 § (GÁ, M).

Platyphylax frauenfeldi Brauer, 1857 - Barcs, Dráva-part (U \& N 1997); Barcs, erdészet (N 1985a, U \& N 1997); Barcs, Szilonics-puszta (U \& N 1997, N \& U 1998); Bélavár, Dráva (U \& N 1992, 1997, N \& U 1998); Kerkaszentkirály, Kerka (U 2004); „Középrigóc“ (Ujhelyi 1981a); Magyarszombatfa (U \& N 1992a, 1997); Örtilos, ártér (U \& N 1997); Örtilos, Dráva-part (N \& U 1995, 1998, U \& N 1997); Sumony (U \& N 1997); Szentborbás (N \& U 1995, U \& N 1997); Szentpéterfölde (U \& N 1997); Vízvár, Dráva-part (U \& N 1997, N \& U 1998); Zákány (U \& N 1997) - Örtilos, Dráva 2000. X. 31.13 § 29 q (Ma, U), 2001. X. 30.1 đ̊ (N, U);

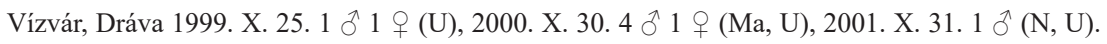

Stenophylax meridiorientalis Malicky, 1980 - Abaliget, Nyáras-v. (N et al. 1985, U \& N 2006); Almamellék, Sas-rét (N \& U 1990); Bakonya, Erdészház (N et al. 1985); Bakonya, Sás-v. (U \& N 2006); „Bélavár” (U 2005); Bükkösd, Korpád, Sormás-v. (N et al. 1985); Cserkút ( $\mathrm{N}$ et al. 1985); Hetvehely, Nyáras-v. (U \& N 2006); Hetvehely, Sás-v. (U \& N 2006); Pécs, Deindol (U \& N 2006); Pécs, Dömörkapu (U \& N 2006); Pécs, Lapis (N et al. 1985); Pécs, Misina (U \& N 2006); Pécs, Tubes (N et al. 1985) - Cserkút 2011. IX. 27. 3 q (U), 2011. IX. 28. 1 q (U); Ibafa, Gyürüfü 2008. X. 11. 1 q (U); Kővágószőlős 2013. X. 6. 2 q (U), 2014. V.

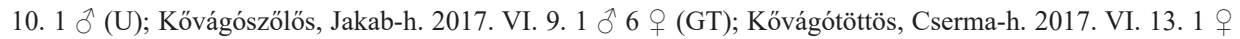

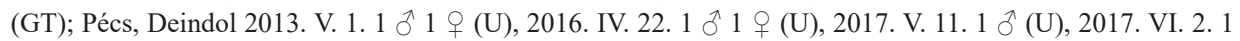

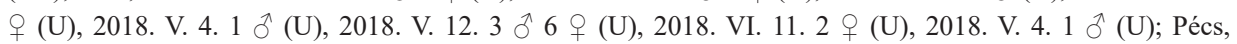
Mecsekszentkút, Szunyola 2014. V. 7. 1 § 3 q (U), 2014. V. 20. 1 q (U), 2014. VI. 2.7 6 q (U).

Stenophylax permistus McLachlan, 1895 - Almamellék, Sas-rét (N \& U 1990); Babócsa, ártér (N \& U 1998); Bakonya, Erdészház (N et al. 1985); Bakonya, Sás-v. (U \& N 2006); Barcs, Csikota (N 1985a); Barcs, 
erdészet (N 1985a); Barcs, halastó (N 1985a); Barcs, Macsilla-domb (N \& U 1998); Barcs, Rinya-Ó-Dráva (N \& U 1998); Barcs, szakiskola (N \& U 1998); Barcs, Szilonics-p. (N \& U 1998); Berzence, Tekeres-berki-p. (N \& U 1998); Böhönye (N \& U 1992); Bükkösd, Korpád, Sormás-v. (N et al. 1985); Csarnóta (N 2000); Cserkút (N et al. 1985); Csertő (N \& U 1990); Csurgó (N \& U 1998); „Darány“ (Ujhelyi 1981a); Darány, Kuti őrház (N 1985a, N \& U 1998); Darány, Nagyberek (N 1985a, N \& U 1995); Darány, Szürűhely-folyás (N 1985a); Darány, temető (N 1985a); Drávapalkonya (N \& U 1995); Drávaszentes (N \& U 1998); Gilvánfa, erdészház (N et al. 1985); Hedrehely ( $N$ et al. 1985); Hetvehely, Nyáras-v. (U \& N 2006); Hetvehely, Sás-v. (U \& N 2006); Homokszentgyörgy (N \& U 1988); Kemse, Háromfa (N \& U 1995); Kerkaszentkirály, Kerka (U 2004); Kisdobsza (N et al. 1985, N \& U 1988); Kisszentmárton, Majláthpuszta (N \& U 1995); Komlósd (N et al. 1985); „Középrigóc“ (Ujhelyi 1981a); Magyarszombatfa (U \& N 1992a); Matty, Keselyősfapuszta (N \& U 1998); Örtilos, Dráva-part (N \& U 1995); Patosfa (N \& U 1990); Pécs, Deindol (U \& N 2006); Pécs, Lapis (N et al. 1985); Pécs, Tubes (N et al. 1985); Potony (N \& U 1998); Siklós, Göntér (N 2000); Siklós-Máriagyüd (N 2000); Szentborbás (U \& N 1992b, N \& U 1998); Tótújfalu, Dráva (N \& U 1998); Tótújfalu, Lugi-e. (N \& U 1998); Vízvár, Dráva (N \& U 1998) - Abaliget, Nyáras-v. 2017. V. 29.1 q (U); Cserkút 2016. V. 23.1 ㅇ

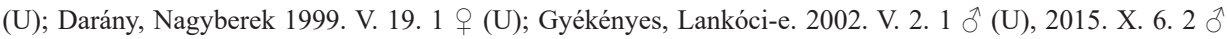
(GÁ, M); Ibafa, Gyürüfü 2006. V. 20. 1 † (Á), 2008. X. 10. 2 đ̊ (U); Kerkaszentkirály, Kerka 2010. XI. 4.1 § (O, U); Kisdobsza 1998. X. 28. 1 † (U); Kővágótöttös, Cserma-h. 2018. V. 31. 1 q (GT); Örtilos, Dráva

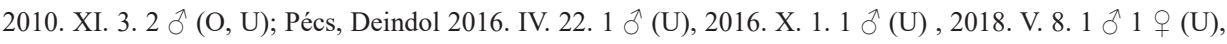

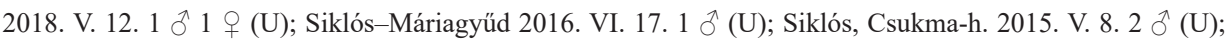
2006. V. 22. $1 \curvearrowright(\mathrm{U})$.

Micropterna lateralis (Stephens, 1837) - Bakonya, Sás-v. (U \& N 2006); Komlósd (N et al. 1985); Magyarszombatfa (U \& N 1992a); Örtilos, Dráva-part (N \& U 1995); Pécs, Deindol (U \& N 2006).

Micropterna nycterobia McLachlan, 1875 - Pécs, Deindol (U \& N 2006).

Micropterna sequax McLachlan, 1875 - Abaliget, Nyáras-v. (U \& N 2006); Bakonya, Sás-v. (U \& N 2006); Cserkút (N et al. 1985); Hetvehely, Nyáras-v. (U \& N 2006); Pécs, Deindol (U \& N 2006); Pécs, Éger-völgy (N et al. 1985); Pécs, Tubes (N et al. 1985) - Cserkút 2011. V. 20.2 q (U); Kővágószőlős 2014. V. 9.1 ○ 1

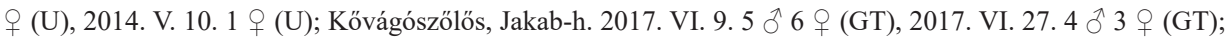
Kővágótöttös, Cserma-h. 2017. VI. 13. 2 đ 1 (GT), 2018. V. 31.2 o 6 q (GT); Pécs, Deindol 2011. V. 30.

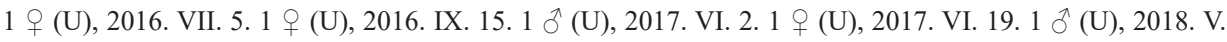
12. 1 (U); 2018. VI. 11. 2 (U); Pécs, Mecsekszentkút, Szunyola 2014. V. 7.1 † (U), 2014. V. 20.7 7

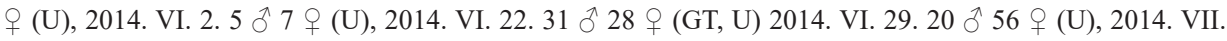

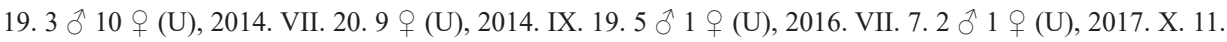

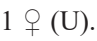

Micropterna testacea (Gmelin, 1798) - Magyarszombatfa (U \& N 1992a).

Chaetopteryx fusca Brauer, 1857 - Örtilos, Dráva-part (N \& U 1995) - Örtilos, Dráva 2000. X. 31.7 đ (Ma, U); Vízvár, Dráva 2000. X. 30. 1 đ̋ (Ma, U), 2005. X. 23. 1 §̊(U).

Chaetopteryx major McLachlan, 1876 - Almamellék, Sas-rét (N \& U 1990); Bükkösd, Gorica (N et al. 1985); Bükkösd, Korpád, Sormás-v. (N et al. 1985); Cserkút (N et al. 1985); Hetvehely, Nyáras-v. (U \& N 2006); Magyarszombatfa (U \& N 1992a); Örtilos, Dráva-part (N \& U 1995, 1998); Őrtilos, Új-Zrínyi-vár (N \& U 1998); Pécs, Deindol (U \& N 2006); Pécs, Éger-völgy (N et al. 1985, U \& N 2006); Zákány (N \& U 1998) - Ibafa, Gyürüfü 2008. X. 10. 2 đ 8 q (Á, U); Kővágószőlős 2013. X. 12. 1 đ(U), 2013. X. 23. 9 đ (U); Kővágótöttös 2013. X. 14. 2 § 4 (U), 2013. X. 30. 1 q (U); Pécs, Éger-v. 2010. XI. 1.1 q (N, U), 2013. X. 2.1 o (U), 2013.

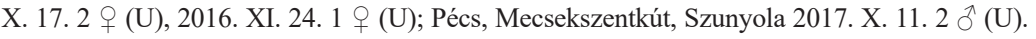

\section{Goeridae}

Goera pilosa (Fabricius, 1775) - Alsószenterzsébet (U 2004); Barcs, halastó (N 1985a); Barcs, Rinya-ÓDráva (N \& U 1998); Bélavár, Almás-berek (N \& U 1998); Bélavár, Dráva (N \& U 1998); Bélavár, Lókaimező (N \& U 1998); Belezna, Mura (N \& U 1998); Csertő (N \& U 1990); Csesztreg-Kerkaújfalu (U 2004); Darány, Kuti örház (N 1985a); Darány, Nagyberek (N \& U 1995); Dobri (U 2004); Drávasztára (N \& U 1995); Gyékényes, kavicsbányató (N \& U 1995); Gyékényes, Lankóci-e. (N \& U 1998); Hetvehely, Bükkösdi-v. (U 
\& N 2006); Kercaszomor (U 2004); Kerkaszentkirály, Kerka (U 2004); Kisdobsza (N \& U 1988); Komlósd (N et al. 1985); Lenti, Bárszentmihályfa (U 2004); Magyarföld (U 2004); Magyarszombatfa (U \& N 1992a); Patosfa (N \& U 1990); Örtilos, ártér (N \& U 1998); Örtilos, Dráva (N \& U 1995); Örtilos, Új-Zrínyi-vár (N \& U 1998); Rédics, Kebele-p. (U 2004); Somogyudvarhely, Dombó-csat. (N \& U 1998); Szentborbás (U \& N 1992b); Tormafölde (U 2004); Tótszerdahely (U 2004); Vízvár, Dráva (N \& U 1995, 1998); Zákány (N \& U 1998) - Barcs, Szilonics-p. 1999. V. 19. 1 đ (U); Bélavár, Almás-berek 2000. V. 4.5 đ 2 q (U); Bélavár, Dráva

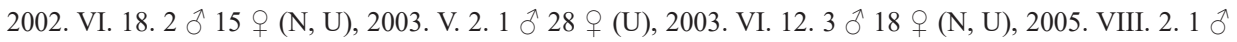
4 ㅇ (U), 2006. V. 16. 2 † (U); Bélavár, Lókai-mező 1999. V. 11.1 (U), 2002. VI. 20. 4 ㅇ (U), 2004. VI. 18. 1 (U); Cserkút 2013. V. 21. 1 đ(U); Drávasztára 2003. VI. 5. 1 đ 1 q (U); Gyékényes, Lankóci-e. 2000.

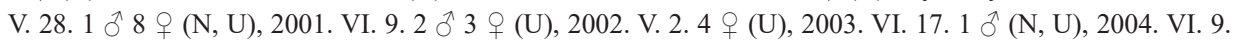

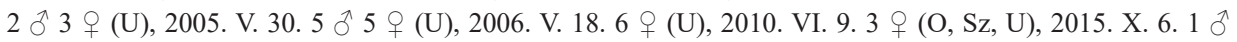
(GÁ, M), 2016. VI. 1. 1 † (GÁ, M, U), 2016. VI. 8. 1 † (GÁ, M, U); Ibafa, Gyürüfü 2007. VI. 22. 1 ð (U); Örtilos, ártér 1999. VII. 1. 5 o (U); Örtilos, Dráva 1999. VI. 30. 1 9 (U), 1999. VIII. 3.1 ^ 4 o (U), 2001.

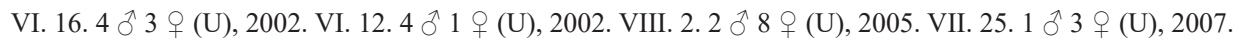

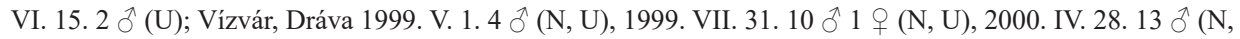

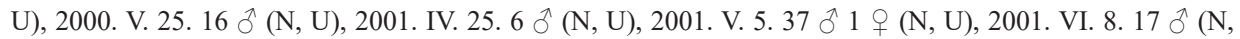

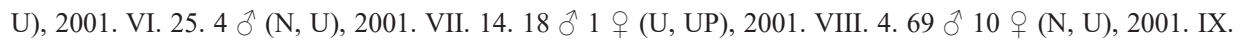

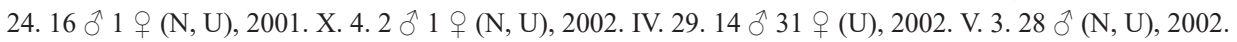

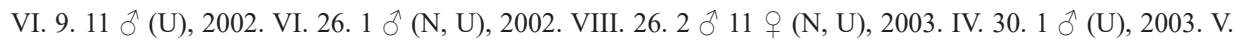

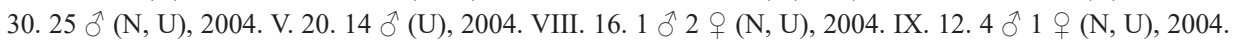

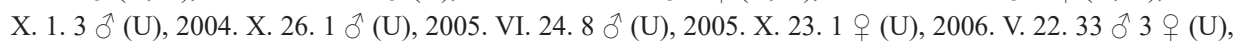

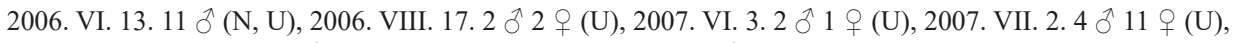
2015. IX. 16. 11 đ 4 ๆ (GÁ, M, U), 2016. V. 28. 13 § 11 q (GÁ, U).

Lithax obscurus (Hagen, 1859) - Abaliget, Nyáras-v. (N et al. 1985, U \& N 2006); Bakonya, Sás-v. (N et al. 1985); Bükkösd, Korpád, Sormás-v. (N et al. 1985); Hetvehely, Bükkösdi-v. (U \& N 2006); Hetvehely, Nyáras-v. (N et al. 1985, N \& U 1990, U \& N 2006); Hetvehely, Sás-v. (U \& N 2006); Kisdobsza (N \& U 1988); Komlósd (N \& U 1998); Lad (N \& U 1990); Magyarszombatfa (U \& N 1992a); Örtilos, Új-Zrínyi-vár (N \& U 1998); Patosfa (N \& U 1990); Pécs, Éger-v. (U \& N 2006); Porrogszentpál, Rigócz-p. (N \& U 1998); Szentlőrinc (N \& U 1990); Zákány (N \& U 1998) - Bélavár, Lókai-mező 2000. IV. 13.1 đ̋ (U) 2002. IV. 15.

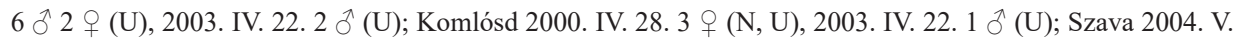
16. $4 \hat{\jmath}(\mathrm{U})$.

Silo nigricornis (Pictet, 1834) - Vízvár, Dráva (U 2005).

Silo pallipes (Fabricius, 1781) - Magyarszombatfa (U \& N 1992a) - Pécs, Deindol 2018. VI. 11. 1 (U). Silo piceus (Brauer, 1857) - Őrtilos, Dráva (N \& U 1995); Tótszerdahely (U 2004); Vízvár, Dráva (U 2005) - Bélavár, Dráva 2002. VI. 18. 1 † (N, U), 2002. X. 17. 1 ㅇ (N, U), 2003. V. 2.155 đ 14 q (U), 2006. V. 16.

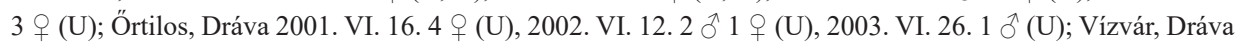

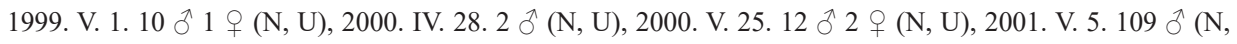

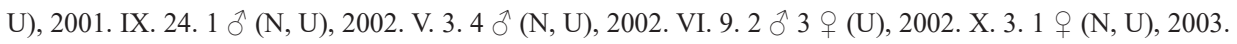

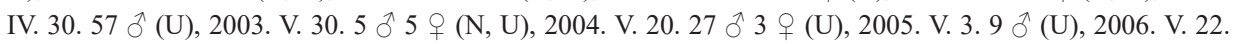

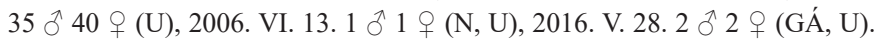

\section{Lepidostomatidae}

Lepidostoma hirtum (Fabricius, 1775) - Csesztreg-Kerkaújfalu (U 2004); Dobri (U 2004); Kercaszomor (U 2004); Kerkaszentkirály, Kerka (U 2004); Kisdobsza (N \& U 1988); Magyarföld (U 2004); Magyarszombatfa (U \& N 1992a); Rédics, Kebele-p. (U 2004); Tótszerdahely (U 2004).

Crunoecia irrorata (Curtis, 1834) - Berzence, források (N \& U 1998); Kercaszomor (U 2004); Magyarszombatfa (U \& N 1992a); Örtilos, Dráva-part (N \& U 1995); Somogyudvarhely, források (N \& U 1998) - Somogyudvarhely, források 1998. VI. 10. 2 đ̊ 2 q (U) 1998. VI. 25.1 đ 1 q (N, U), 1999. VII. 2. 10 ๙ 3 우(U), 2003. VI. 23. 1 우(U). 


\section{Leptoceridae}

Athripsodes albifrons (Linnaeus, 1758) - Kerkaszentkirály, Kerka (U 2004); Örtilos, Dráva (N \& U 1995) -

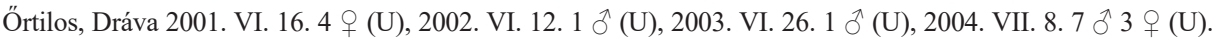

Athripsodes aterrimus (Stephens, 1836) - Babócsa, ártér (N \& U 1998); Barcs, halastó (N 1985a); Barcs, Kisbók (N \& U 1998); Barcs, Rinya-Ó-Dráva (N \& U 1998); Bélavár, Dráva (N \& U 1998); Bélavár, Lókaimező (N \& U 1998); Berzence, kavicsbányatavak (N \& U 1998); Darány, Nagyberek (N 1985a, N \& U 1995, 1998); Drávapalkonya (N \& U 1998); Heresznye (N \& U 1998); Kemse, Háromfa (N \& U 1995); Kisdobsza (N et al. 1985); Kisszentmárton, Majláthpuszta (N \& U 1995); Komlósd (N et al. 1985); Magyarföld (U 2004); Magyarszombatfa (U \& N 1992a); Örtilos, Dráva (N \& U 1995); Patosfa (N \& U 1990); Potony (N \& U 1995, 1998); Szentborbás (U \& N 1992b, N \& U 1998); Szentlőrinc (N \& U 1990); Szulimán (N \& U 1990); Tótújfalu, Dráva (N \& U 1998); Tótújfalu, Lugi-e. (N \& U 1998); Vejti, Dráva (N \& U 1995, 1998); Vízvár, Dráva (N \& U 1998) - Barcs, Rinya-Ó-Dráva 1999. V. 19. 5 o 1 q (U); Bélavár, Dráva 2002. VI. 18.11 o 4

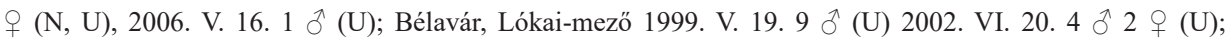
Drávasztára 2006. V. 23. 1 đૈ (U); Gordisa, Mattyi-tó 2004. VI. 8. 3 đ 12 \& (U); Gyékényes, Lankóci-e. 2001.

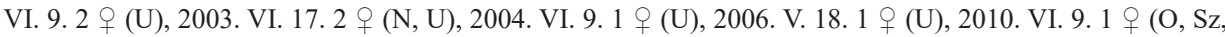
U), 2011. V. 19. 1 + (O, U), 2016. VI. 8.3 \& (GÁ, M, U); Vízvár, Dráva 2006. V. 22.2 \& (U), 2006. VI. 13. 1 ㅇ $(\mathrm{N}, \mathrm{U}), 2016 . \mathrm{V} .28 .2$ 乃 3 + (GÁ, U).

Athripsodes bilineatus (Linnaeus, 1758) - Alsószenterzsébet (U 2004); Kercaszomor (U 2004); Magyarszombatfa (U \& N 1992a).

Athripsodes cinereus (Curtis, 1834) - Alsószenterzsébet (U 2004); Dobri (U 2004); Kerkaszentkirály, Kerka (U 2004); Kerkaszentmihály-Margitmajor, Lendva (U 2004); Örtilos, Dráva (N \& U 1995); Rédics, Kebele-p. (U 2004); Somogyudvarhely, Dombó-csat. (N \& U 1998); Tormafölde (U 2004) - Bélavár, Dráva 2002. VI.

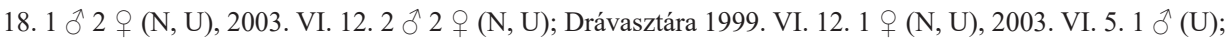
Gyékényes, Lankóci-e. 2001. VI. 9. 1 † (U), 2003. VI. 17. 4 ○ 5 q (N, U), 2010. VI. 9.1 q (O, Sz, U); Örtilos,

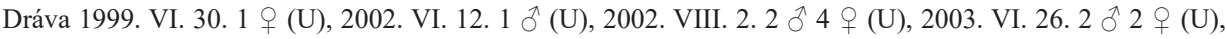

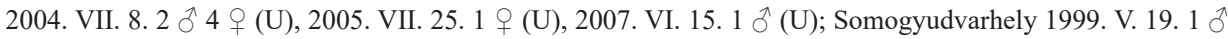
1 q (U); Vízvár, Dráva 1999. V. 19. 1 đo (U), 2002. VIII. 26. 2 † (N, U), 2007. VII. 2.1 ô(U).

Ceraclea alboguttata (Hagen, 1860) - Barcs, halastó (N 1985a, N \& U 1995); Barcs, halastó I. (N \& U 1998); Barcs, Kisbók (N \& U 1998); Bélavár, Lókai-mező (N \& U 1998); Böhönye (N \& U 1992); Darány, Nagyberek (N \& U 1998); Dobri (U 2004); Drávapalkonya (N \& U 1995); Drávasztára (N \& U 1995, 1998); Gordisa, Mattyi-tó (N \& U 1995); Gyékényes, kavicsbányató (N \& U 1995); Kercaszomor (U 2004); Kerkaszentkirály, Kerka (U 2004); Kisdobsza (N et al. 1985, N \& U 1988); Kisharsány (N 2000); Magyarföld (U 2004); Magyarszombatfa (U \& N 1992a); Muraszemenye (U 2004); Örtilos, Dráva (N \& U 1995); Pellérd, halastavak (U \& N 2006); Szentborbás (U \& N 1992b, N \& U 1998); Szentlőrinc (N \& U 1990); Tótszerdahely (U 2004); Tótújfalu, Dráva (N \& U 1998); Vízvár, Dráva (N \& U 1995); Vízvár, község (N \& U 1995) - Barcs,

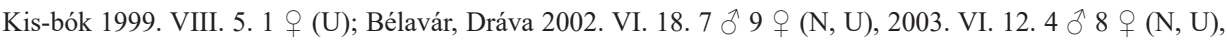

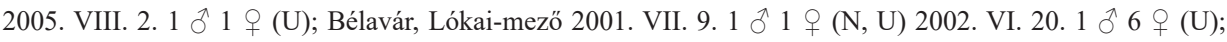
Drávapalkonya 1999. VI. 28. 1 (U); Drávasztára 1999. VI. 12.1 \& (N, U), 1999. VIII. 9.1 đ 3 \& (U), 2003.

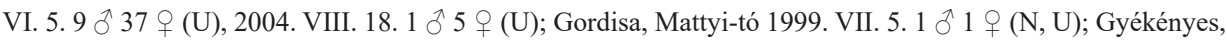
Lankóci-e. 2003. VI. 17. 5 ô 2 ㅇ (N, U); Örtilos, ártér 1999. VII. 1. 2 ㅇ (U); Örtilos, Dráva 1999. VIII. 3. 1

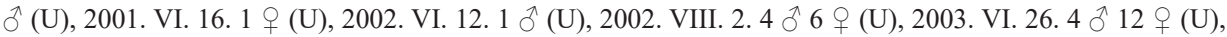

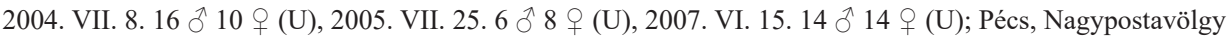
2018. V. 28.1 + (GT); Siklós-Máriagyúd 2016. VI. 17. 1 đ (U); Vízvár, Dráva 1999. VII. 31.1 đ (N, U),

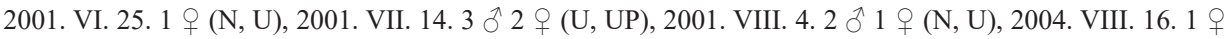
(N, U), 2004. IX. 12. 1 § (N, U), 2007. VII. 2. 5 q (U).

Ceraclea annulicornis (Stephens, 1836) - Alsószenterzsébet (U 2004); Barcs, halastó (N 1985a); Belezna, Mura (N \& U 1998); Csertő (N \& U 1990); Drávapalkonya (N \& U 1995); Drávasztára (N \& U 1995, 1998); Kisdobsza (N et al. 1985, N \& U 1988); Kisszentmárton, Majláthpuszta (N \& U 1995); Magyarszombatfa (U \& N 1992a); Muraszemenye (U 2004); Örtilos, Dráva (N \& U 1995, 1998); Somogyapáti (N \& U 1990); Somogyudvarhely, Dombó-csat. (N \& U 1998); Szentborbás (U \& N 1992b); Szulimán (N \& U 1990); Vejti, 
Dráva (N \& U 1995); Vízvár, Dráva (N \& U 1995, 1998); Zákány (N \& U 1998) - Bélavár, Dráva 2002. VI.

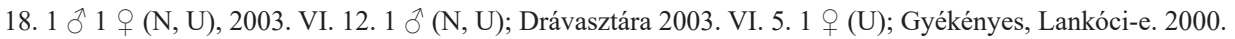

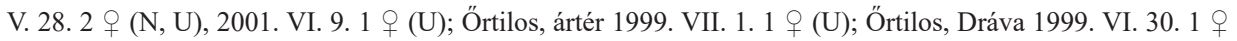

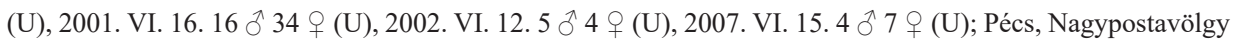

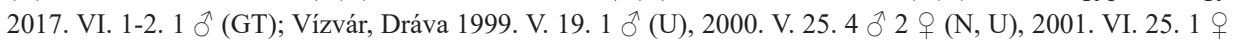
(N, U), 2002. VI. 9. 1 ふै(U).

Ceraclea aurea (Pictet, 1834) - Barcs, halastó (N 1985a, N \& U 1995); Bükkösd, Szentdomján (U \& N 2006); „Darány“ (Ujhelyi 1981a); Darány, temető (N et al. 1985); Drávapalkonya (N \& U 1995); Drávasztára (N \& U 1995); Kisdobsza (N \& U 1988); Magyarszombatfa (U \& N 1992a); Muraszemenye (U 2004); Siklós, Göntér (N 2000); Somogyapáti (N \& U 1990); Szentborbás (U \& N 1992b, N \& U 1998); Tormafölde (N et al. 1985); Tótszerdahely (U 2004); Vejti, Dráva (N \& U 1995) - Bélavár, Dráva 2002. VI. 18. 19 đ 30 q (N,

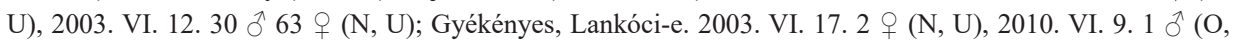
Sz, U); Kövágótöttös, Cserma-h. 2017. VI. 13. 1 đ(GT); Örtilos, Dráva 1999. VI. 30.4 § 5 q (U), 1999. VIII.

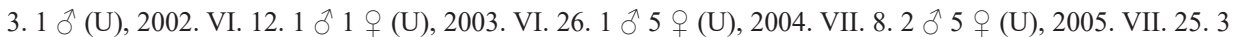
q (U), 2007. VI. 15. 23 đ 40 † (U); Pécs, Nagypostavölgy 2017. VI. 1-2. 1 ઈ (GT); Siklós-Máriagyüd 2016.

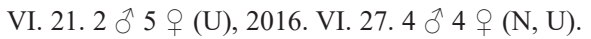

Ceraclea dissimilis (Stephens, 1836) - Alsószenterzsébet (U 2004); Babócsa, ártér (N \& U 1998); Barcs, erdészet (N 1985a); Barcs, halastó (N 1985a); Barcs, halastó I. (N \& U 1998); Barcs, Kisbók (N \& U 1998); Barcs, Macsilla-domb (N \& U 1998); Barcs, szakiskola (N \& U 1998); Bélavár, Dráva (N \& U 1998); Bélavár, Lókai-mezö (N \& U 1998); Belezna, Mura (N \& U 1998); Böhönye (N \& U 1992); Bükkösd, Bükkösdi-v. (U \& N 2006); Cserkút (N et al. 1985); Csertő (N \& U 1990); Csesztreg-Kerkaújfalu (U 2004); Csörnyefölde (N et al. 1985); „Darány“ (Ujhelyi 1981a); Darány, Kuti örház (N 1985a); Darány, Nagyberek (N 1985a, N \& U 1998); Darány, temető (N et al. 1985); Diósviszló (N 2000); Dobri (U 2004); Drávapalkonya (N \& U 1995, 1998); Drávaszabolcs, Holt-Fekete-víz (N \& U 1998); Drávasztára (N \& U 1995, 1998); Felsőszentmárton, Korcsina-csat. (N \& U 1998); Gordisa, Mattyi-tó (N \& U 1995); Gyékényes, kavicsbányató (N \& U 1995); Gyékényes, Lankóci-e. (N \& U 1998); Heresznye (N \& U 1998); Hetvehely, Bükkösdi-v. (U \& N 2006); Homokszentgyörgy (N \& U 1988); Kemse, Háromfa (N \& U 1995); Kercaszomor (U 2004); Kerkaszentkirály, Kerka (U 2004); Kisdobsza (N et al. 1985, N \& U 1988); Kisharsány (N 2000); Kisszentmárton, Majláthpuszta (N \& U 1995); Komlósd (N et al. 1985, N \& U 1998); „Középrigóc“ (Ujhelyi 1981a); Magyarföld (U 2004); Magyarszombatfa (U \& N 1992a); Muraszemenye (U 2004); Örtilos, ártér (N \& U 1998); Örtilos, Dráva (N \& U 1995, 1998); Örtilos, Új-Zrínyi-vár (N \& U 1998); Patosfa (N \& U 1990); Pécs, Deindol (U \& N 2006); Pellérd, halastavak (U \& N 2006); Péterhida (N \& U 1998); Potony, Lugi-erdő (N \& U 1995, 1998); Rédics, Kebele-p. (U 2004); Siklós, Göntér (N 2000); Somogyapáti (N \& U 1990); Siklós-Máriagyüd (N 2000); Somogyudvarhely, Dombó-csat. (N \& U 1998); Szaporca, Kisinci (N \& U 1998); Szentborbás (U \& N 1992b, N \& U 1998); Szentlőrinc (N \& U 1990); Szulimán (N \& U 1990); Tormafölde (N et al. 1985); Tótszerdahely (U 2004); Tótújfalu, Dráva (N \& U 1998); Vejti, Dráva (N \& U 1995, 1998); Vízvár, Dráva (N \& U 1995, 1998); Vízvár, község (N \& U 1995); Zákány (N \& U 1998); Zalabaksa (U 2004) - Almamellék, Almás-p. 1998. VII. 19. 2 † (U); Bakonya, Nagy-Rege 2017. VI. 12. 1 đ 2 q (U); Barcs, Kis-bók 1999. VIII. 5.35 ठૈ

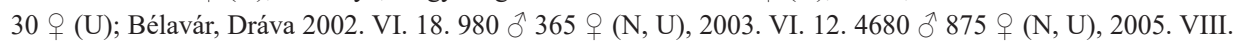

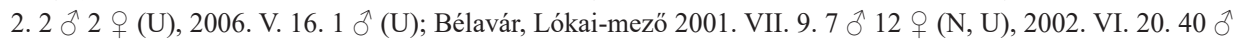
55 q (U), 2004. VI. 18. 9 đ 10 q (U); Darány, Nagyberek 1999. V. 19. 2 q (U); Drávapalkonya 1999. VI. 28.

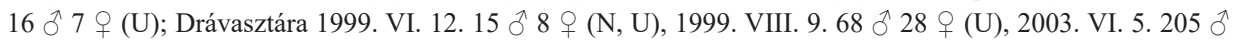

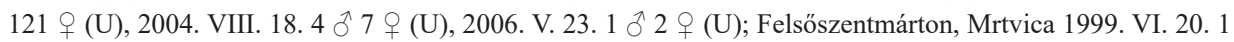

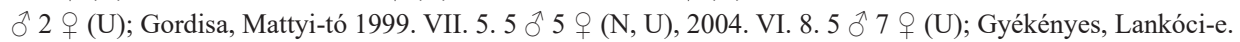

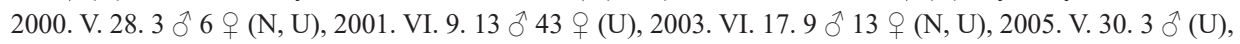
2006. VI. 14. 1 q (U), 2010. VI. 9.5 申 (O, Sz, U); Örtilos, ártér 1999. VII. 1. 202 đ 86 q (U); Örtilos, Dráva

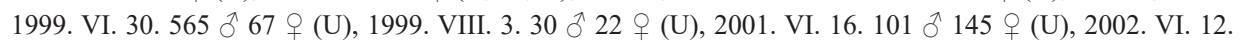

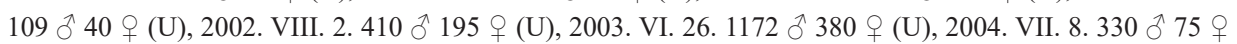
(U), 2005. VII. 25. 137 ^ 143 q (U), 2007. VI. 15. $520 \precsim 275$ ○ (U); Pécs, Nagypostavölgy 2017. VI. 1-2. 4 † (GT), 2018. VI. 4. 1 đ(GT); Siklós-Máriagyüd 2016. VI. 17. 1 đ(U), 2016. VI. $21.1 \delta 1$ (U), 2016. 
VI. 27. 1 đ 3 ㅇ (N, U); Somogyudvarhely 1999. VIII. 4. 1 đo 1 q (U); Vízvár, Dráva 1999. VII. 31.25 đ 13

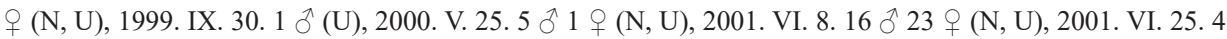

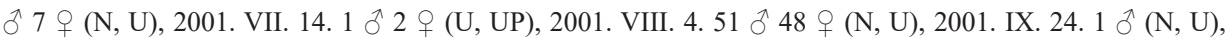

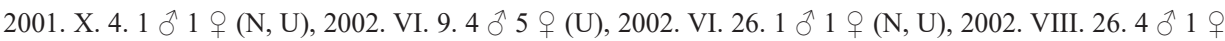

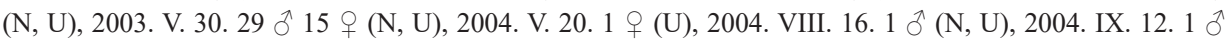

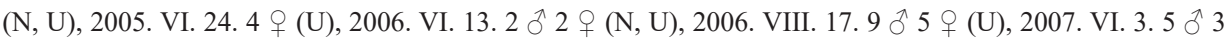

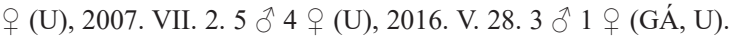

Ceraclea fulva (Rambur, 1842) - Kisdobsza (N \& U 1988); Kisszentmárton, Majláthpuszta (N \& U 1995); Pécs, Deindol (U \& N 2006); Szulimán (N \& U 1990).

Ceraclea riparia (Albarda, 1874) - „Darány“ (Ujhelyi 1981a); Kercaszomor (U 2004); Magyarszombatfa (U \& N 1992a); Örtilos, Dráva (N \& U 1995); Vejti, Dráva (N \& U 1995) - Siklós-Máriagyüd 2016. VI. 27. $8 \delta 4$ \& $(\mathrm{N}, \mathrm{U})$.

Ceraclea senilis (Burmeister, 1839) - Babócsa, ártér (N \& U 1998); Barcs, halastó (N 1985a); Barcs, halastó I. (N \& U 1998); Barcs, Rinya-Ó-Dráva (N \& U 1998); Barcs, szakiskola (N \& U 1998); Darány, Kuti-őrház (N \& U 1998); Darány, Nagyberek (N \& U 1995); Drávapalkonya (N \& U 1998); Drávaszabolcs, Holt-Feketevíz (N \& U 1998); Kisszentmárton, Majláthpuszta (N \& U 1995); Somogyapáti (N \& U 1990); Szentlörinc (N \& U 1990) - Bélavár, Lókai-mező 2004. VI. 18. 1 q (U); Gordisa, Mattyi-tó 1999. VII. 5. 9 q (N, U), 2004. VI. 8.1 q (U); Gyékényes, Lankóci-e. 2011. V. 19. 1 q (O, U); Vízvár, Dráva 2016. V. 28. 1 q (GÁ, U).

Mystacides azurea (Linnaeus, 1761) - Bélavár, Lókai-mező (N \& U 1998); Csesztreg-Kerkaújfalu (U 2004); Dobri (U 2004); Kercaszomor (U 2004); Lenti, Bárszentmihályfa (U 2004); Magyarföld (U 2004); Magyarszombatfa (U \& N 1992a); Örtilos, Dráva (N \& U 1995); Somogyudvarhely, Dombó-csat. (N \& U 1998) - Bélavár, Dráva 2002. VI. 18. 4 đ 1 q (N, U), 2005. VIII. 2. 1 đ 1 q (U); Bélavár, Lókai-mező 2002. VI. 20. 1 q (U); Gyékényes, Lankóci-e. 2010. VI. 9. 1 § (O, Sz, U); Örtilos, Dráva 2005. VII. 25. 2 早 (U);

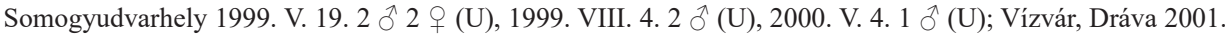

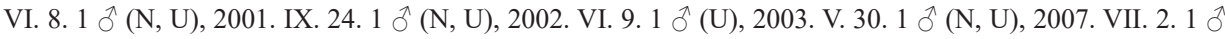
1 ( $(\mathrm{U})$.

Mystacides longicornis (Linnaeus, 1758) - Alsószenterzsébet (U 2004); Barcs, halastó (N 1985a, N \& U 1995); Böhönye (N \& U 1992); Bükkösd, Szentdomján (U \& N 2006); Dobri (U 2004); „Középrigóc“ (Ujhelyi 1981a); Kercaszomor (U 2004); Kerkaszentkirály, Kerka (U 2004); Kisszentmárton, Majláthpuszta (N \& U 1995); Magyarföld (U 2004); Magyarszombatfa (U \& N 1992a); Muraszemenye (U 2004); Örtilos, Dráva (N \& U 1995); Patosfa (N \& U 1990); Rédics, Kebele-p. (U 2004); Siklós, Csukma-h. (N 2000); Somogyapáti (N \& U 1990); Tormafölde (N et al. 1985) - Almamellék, Almás-p. 1998. VII. 19. 18 q (U); Gyékényes, Lankóci-e. 2001. VI. 9.2 (U); Örtilos, Dráva 2001. VI. 16. 1 § 1 (U), 2002. VI. 12.1 (U), 2007. VI. $15.1 \delta(\mathrm{U})$.

Mystacides nigra (Linnaeus, 1758) - Barcs, halastó (N 1985a); Berzence, Dombó-csat. (N \& U 1998); Berzence, Tekeres-berki-p. (N \& U 1998); Csertő (N \& U 1990); Drávasztára (N \& U 1995); Hegyszentmárton (N 2000); Magyarszombatfa (U \& N 1992a); Örtilos, Dráva (N \& U 1995); Somogyapáti (N \& U 1990); Somogyudvarhely, Dombó-csat. (N \& U 1998); Szulimán (N \& U 1990); Tormafölde (N et al. 1985); Vejti, Dráva (N \& U 1998) - Gyékényes, Lankóci-e. 2001. VI. 9. đ̊ ㅇ (U); Örtilos, Dráva 2005. VII. 25. 1 \& (U); Vízvár, Dráva 2007. VII. 2. 1 đ1 1 \& (U).

Triaenodes bicolor (Curtis, 1834) - Barcs, halastó (N 1985a, N \& U 1995); Barcs, szakiskola (N \& U 1998); Bélavár, Dráva (N \& U 1998); Bélavár, Lókai-mező (N \& U 1998); Böhönye (N \& U 1992); Csertő (N \& U 1990); Darány, Nagyberek (N 1985a, N \& U 1995, 1998); Kisdobsza (N et al. 1985); Magyarszombatfa (U \& N 1992a);Kisszentmárton, Majláthpuszta (N \& U 1995); Szaporca, Kisinci (N \& U 1998); Tótújfalu, Dráva (N \& U 1998) - Bélavár, Dráva 2002. VI. 18. 1 q (N, U); Darány, Nagyberek 1999. VII. 12.1 (U), 2000. VI. 6.2 † (N, U); Gordisa, Mattyi-tó 1999. VII. 5.1 q (N, U); Gyékényes, Lankóci-e. 2001. VI. 9.1 q (U), 2003. VI. 17. 2 ㅇ (N, U), 2010. VI. 9. 1 đ(O, Sz, U); Vízvár, Dráva 2001. VIII. 4.2 ㅇ (N, U), 2003. V. 30.1 ㅇ (N, U), 2004. V. 20. 1 † (U), 2007. VI. 3.1 \& (U).

Ylodes kawraiskii (Martynov, 1909) - „Darány“ (Ujhelyi 1981a); Darány, temető (N et al. 1985). 
Ylodes simulans (Tjeder, 1929) - Alsószenterzsébet (U 2004); Csesztreg-Kerkaújfalu (U 2004); Magyarszombatfa (U \& N 1992a); Vejti, Dráva (N \& U 1998).

Erotesis baltica McLachlan, 1877 - Vízvár, Dráva 2006. V. 22. 1 đ (U), 2016. V. 28. 1 \& (GÁ, U).

Oecetis furva (Rambur, 1842) - Almamellék, Sas-rét (N \& U 1990); Barcs, halastó (N 1985a, N \& U 1995); Barcs, halastó I. (N \& U 1998); Barcs, Rinya-Ó-Dráva (N \& U 1998); Barcs, szakiskola (N \& U 1998); Bélavár, Dráva (N \& U 1998); Böhönye (N \& U 1992); Csertő (N \& U 1990); „Darány“ (Ujhelyi 1981a); Darány, Kuti-őrház (N \& U 1998); Darány, Nagyberek (N 1985a, N \& U 1995, 1998); Drávapalkonya (N \& U 1995, 1998); Drávaszabolcs, Holt-Fekete-víz (N \& U 1998); Gordisa, Mattyi-tó (N \& U 1995); Kisdobsza (N \& U 1988); Kisszentmárton, Majláthpuszta (N \& U 1995); Magyarszombatfa (U \& N 1992a); Patosfa (N \& U 1990); Somogyapáti (N \& U 1990); Szaporca, Kisinci (N \& U 1998); Szentborbás (U \& N 1992b, N \& U 1998); Szentlőrinc (N \& U 1990); Vejti, Dráva (N \& U 1995, 1998) - Almamellék, Almás-p. 1998. VII. 19. 18 † (U); Barcs, Kis-bók 1999. VIII. 5. 1 đ̋ (U); Bélavár, Lókai-mező 2001. VII. 9. 4 đ 2 \& (N, U); Cserkút 2013. V. 21.1 (U); Darány, Nagyberek 1999. VII. 12. 1 đ 5 q (U), 2000. VI. 6.1 \& (N, U); Gordisa, Mattyitó 1999. VII. 5. 1 † (N, U), 2004. VI. 8. 1 đ̋(U); Gyékényes, Lankóci-e. 2003. VI. 17. 1 \& (N, U); Somogyudvarhely 1999. VIII. 4. 7 đ 1 \& (U); Vízvár, Dráva 2003. V. 30.1 \& (N, U), 2006. V. 22.1 \& (U).

Oecetis lacustris (Pictet, 1834) - Abaliget, Nyáras-v. (U \& N 2006); Alsószenterzsébet (U 2004); Babócsa, ártér (N \& U 1998); Barcs, halastó (N 1985a, N \& U 1995); Barcs, halastó I. (N \& U 1998); Barcs, Macsilladomb (N \& U 1998); Barcs, szakiskola (N \& U 1998); Bélavár, Dráva (N \& U 1998); Bélavár, Lókai-mező (N \& U 1998); Böhönye (N \& U 1992); Bükkösd, Bükkösdi-v. (U \& N 2006); Csesztreg-Kerkaújfalu (U 2004); Darány, Nagyberek (N 1985a); Dobri (U 2004); Drávapalkonya (N \& U 1995, 1998); Drávaszabolcs, HoltFekete-víz (N \& U 1998); Drávasztára (N \& U 1995, 1998); Gordisa, Mattyi-tó (N \& U 1995); Heresznye (N \& U 1998); Hetvehely, Bükkösdi-v. (U \& N 2006); Homokszentgyörgy (N \& U 1988); Kisdobsza (N et al. 1985, N \& U 1988); Kisszentmárton, Majláthpuszta (N \& U 1995); Komlósd (N \& U 1998); Magyarszombatfa (U \& N 1992a); Muraszemenye (U 2004); Örtilos, Dráva (N \& U 1995); Patosfa (N \& U 1990); Péterhida (N \& U 1998); Potony (N \& U 1998); Somogyapáti (N \& U 1990); Somogyudvarhely, Dombó-csat. (N \& U 1998); Szaporca, Kisinci (N \& U 1998); Szentborbás (U \& N 1992b); Szulimán (N \& U 1990); Tótszerdahely (U 2004); Tótújfalu, Dráva (N \& U 1998); Vejti, Dráva (N \& U 1995, 1998); Vízvár, Dráva (N \& U 1998) Almamellék, Almás-p. 1998. VII. 19. 1 đ 23 q (U); Bakonya, Nagy-Rege 2017. VI. 12.1 q (U); Barcs, Kisbók 1999. VIII. 5. 2 đ(U); Bélavár, Dráva 2002. VI. 18. 1 đ 3 q (N, U), 2003. VI. 12.1 q (N, U); Bélavár, Lókai-mező 2002. VI. 20. 2 † (U), 2004. VI. 18. 1 q (U); Cserkút 2013. V. 21. 1 đ 7 † (U); Darány, Nagyberek 1999. VII. 12. 1 ð(U), 2000. VI. 6. 1 ^ 4 q (N, U); Drávapalkonya 1999. VI. 28. 3 q (U); Gordisa, Mattyi-tó 1999. VII. 5. 1 đ 1 (N, U), 2004. VI. 8.4 q (U); Gyékényes, Lankóci-e. 2000. V. 28. 23 q (N,

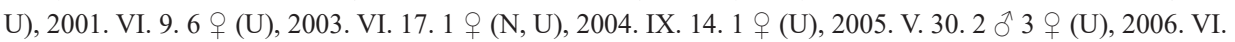

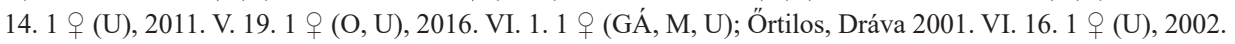

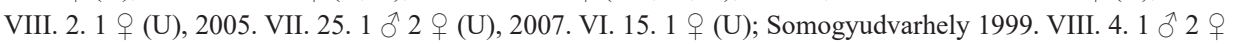
(U); Vízvár, Dráva 1999. VII. 31. 3 q (N, U), 2001. VI. 8. 1 § 5 q (N, U), 2001. VI. 25. 3 q (N, U), 2001.

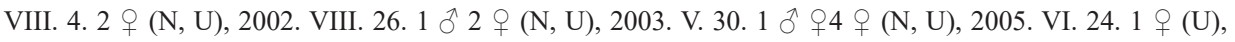

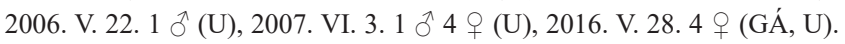

Oecetis notata (Rambur, 1842) - Almamellék, Sas-rét (N \& U 1990); Barcs, halastó (N 1985a, N \& U 1995); Barcs, Kisbók (N \& U 1998); Barcs, szakiskola (N \& U 1998); Bélavár, Dráva (N \& U 1998); Bélavár, Lókai-mező (N \& U 1998); Böhönye (N \& U 1992); Csertő (N \& U 1990); Darány, Kuti-őrház (N \& U 1998); Darány, Nagyberek (N \& U 1995, 1998); Diósviszló (N 2000); Dobri (U 2004); Drávapalkonya (N \& U 1995); Drávaszabolcs, Holt-Fekete-víz (N \& U 1998); Drávasztára (N \& U 1995, 1998); Drávatamási (N \& U 1998); Felsőszentmárton, Korcsina-csat. (N \& U 1998); Gordisa, Mattyi-tó (N \& U 1995); Kemse, Háromfa (N \& U 1995); Kercaszomor (U 2004); Kerkaszentkirály, Kerka (U 2004); Kisdobsza (N et al. 1985, N \& U 1988); Kisharsány (N 2000); Kisszentmárton, Majláthpuszta (N \& U 1995); Komlósd (N \& U 1998); „Középrigóc“ (Ujhelyi 1981a); Magyarföld (U 2004); Magyarszombatfa (U \& N 1992a); Muraszemenye (U 2004); Örtilos, ártér (N \& U 1998); Örtilos, Dráva (N \& U 1995); Patosfa (N \& U 1990); Pécs, Deindol (U \& N 2006); Potony (N \& U 1998); Siklós, Csukma-h. (N 2000); Siklós, Göntér (N 2000); Siklós-Máriagyüd (N 2000); Somogyapáti (N \& U 1990); Szentborbás (U \& N 1992b, N \& U 1998); Tótszerdahely (U 2004); Tótújfalu, 
Dráva (N \& U 1998); Vejti, Dráva (N \& U 1995, 1998); Vízvár, Dráva (N \& U 1995); Vízvár, község (N \& U 1995); Zalabaksa (U 2004) - Almamellék, Almás-p. 1998. VII. 19. 2 đ 5 q (U); Bakonya, Nagy-Rege 2017. VI. 12. 8 \ 7 (U); Barcs, Kis-bók 1999. VIII. 5. 3 đ 2 (U); Bélavár, Dráva 2002. VI. 18. 16 đ 27 q (N,

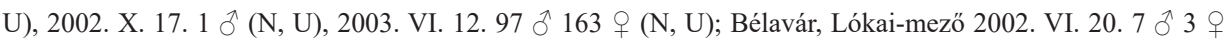

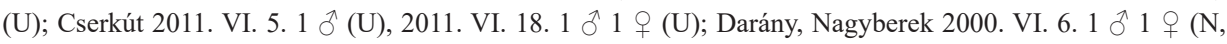
U); Drávapalkonya 1999. VI. 28. 6 đ 12 (U); Drávasztára 1999. VI. 12. 3 đ 4 (N, U), 1999. VIII. 9. 160

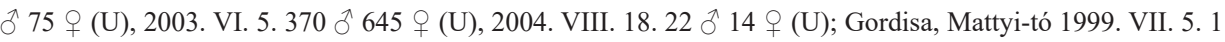

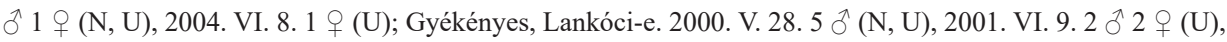
2004. VI. 9.1 (U), 2004. IX. 14. 2 đ (U); Kövágótöttös, Cserma-h. 2018. V. 31.2 đ 1 (GT); Örtilos, ártér

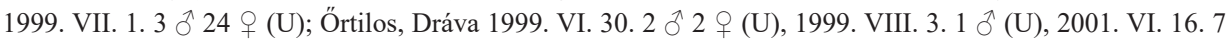

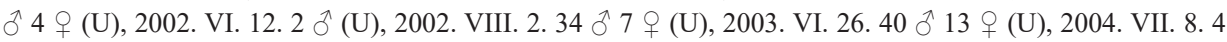
đ(U), 2007. VI. 15. 2 ๙ 2 ㅇ (U); Pécs, Deindol 2018. VIII. 13. 1 đ (U); Pécs, Mecsekszentkút, Szunyola 2014. VI. 29. 4 đ 11 9 (U), 13. 8. 20141 † (GT, U); Pécs, Nagyárpád, Tüskésrét 2018. VI. 4.1 đ (GT); Pécs, Nagypostavölgy 2017. VI. 1-2. $2 \lesssim 1$ † (GT), 2017. VI. 20. 1 q (GT), 2017. VII. 10-18. 2 § 6 (GT), 2017.

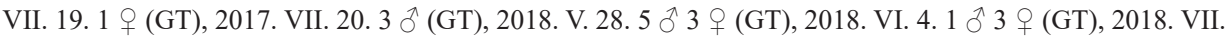

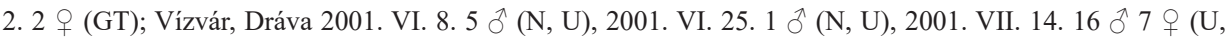

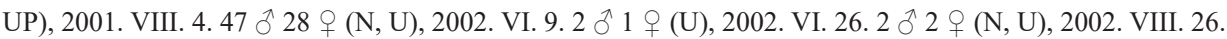

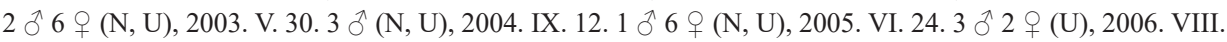

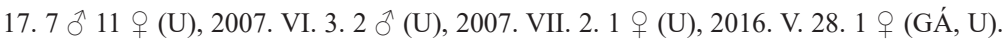

Oecetis ochracea (Curtis, 1825) - Abaliget, Nyáras-v. (N et al. 1985); Almamellék, Sas-rét (N \& U 1990); Alsószenterzsébet (U 2004); Babócsa, ártér (N \& U 1998); Babócsa, Rinya (N \& U 1998); Barcs, erdészet (N 1985a); Barcs, erdészház (N 1985a); Barcs, halastó (N 1985a, N \& U 1995); Barcs, Kisbók (N \& U 1998); Barcs, Macsilla-domb (N \& U 1998); Barcs, Rinya-Ó-Dráva (N \& U 1998); Barcs, szakiskola (N \& U 1998); Barcs, Szilonics-p. (N \& U 1998); Bélavár, Dráva (N \& U 1998); Bélavár, Lókai-mező (N \& U 1998); Böhönye (N \& U 1992); Bükkösd, Szentdomján (U \& N 2006); Csarnóta (N 2000); Csertő (N \& U 1990); Csesztreg-Kerkaújfalu (U 2004); „Darány“ (Ujhelyi 1981a); Darány, Kuti őrház (N 1985a, N \& U 1998); Darány, Nagyberek (N 1985a, N \& U 1995, 1998); Diósviszló (N 2000); Dobri (U 2004); Drávapalkonya (N \& U 1998); Drávaszabolcs, Holt-Fekete-víz (N \& U 1998); Drávasztára (N \& U 1998); Felsőszentmárton, Korcsina-csat. (N \& U 1998); Felsőszentmárton, Mrtvica (N \& U 1998); Gordisa, Mattyi-tó (N \& U 1995); Gyékényes, kavicsbányató (N \& U 1995); Gyékényes, Lankóci-e. (N \& U 1998); Hedrehely (N et al. 1985); Heresznye (N \& U 1998); Homokszentgyörgy (N \& U 1988); Kercaszomor (U 2004); Kerkaszentkirály, Kerka (U 2004); Kisdobsza (N et al. 1985, N \& U 1988); Kisszentmárton, Majláthpuszta (N \& U 1995); Komlósd (N \& U 1998); „Középrigóc“ (Ujhelyi 1981a); Magyarszombatfa (U \& N 1992a); Matty, Keselyősfapuszta (N \& U 1998); Mike (N et al. 1985); Muraszemenye (U 2004); Örtilos, ártér (N \& U 1998); Örtilos, Dráva (N \& U 1995); Patosfa (N \& U 1990); Pellérd (N et al. 1985); Pécs, Deindol (U \& N 2006); Péterhida (N \& U 1998); Somogyapáti (N \& U 1990); Somogyudvarhely, Dombó-csat. (N \& U 1998); Szaporca, Kisinci (N \& U 1998); Szava (N 2000); Szentborbás (U \& N 1992b, N \& U 1998); Szentlörinc (N \& U 1990); Szulimán (N \& U 1990); Tótszerdahely (U 2004); Vejti, Dráva (N \& U 1995, 1998); Vízvár, Dráva (N \& U 1995, 1998); Vízvár, község (N \& U 1995) - Almamellék, Almás-p. 1998. VII. 19. 2 ๆ (U); Barcs, Kis-bók 1999. VIII. 5.8 ð 16

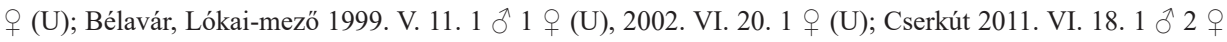
(U); Darány, Nagyberek 1999. VII. 12. 3 申 (U), 2000. VI. 6. 2 đ 14 q (N, U); Drávasztára 1999. VI. 12. 2 ๙

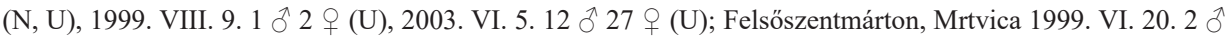

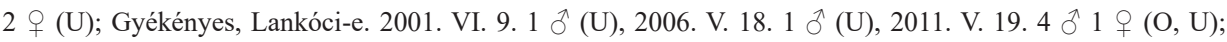
Kővágószőlős 2013. IX. 6. 1 § 1 q (U), 2014. VI. 28. 1 q (GT, U), 2014. VIII. 19. 1 § (GT, U); Örtilos, ártér

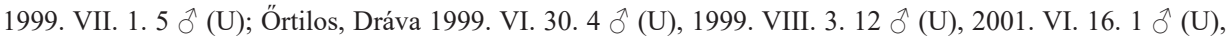

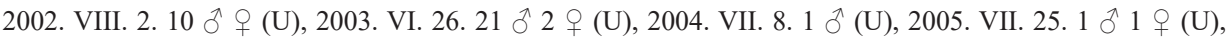
2007. VI. 15. 1 §ิ (U); Pécs, Deindol 2016. VI. 28. 1 \& (U); Pécs, Nagyárpád, Tüskésrét 2018. VI. 4. 1 9 (GT); Pécs, Nagypostavölgy 2017. VI. 1-2. 1 đ(GT); Siklós-Máriagyüd 2016. VI. 17. 7 \& (U), 2016. VI. $21.1 \delta$ (U), 2016. VI. 27. 2 ๙ (N, U); Somogyudvarhely 1999. VIII. 4. 9 ð 16 † (U); Szava, Szőlőhegy 2013. VII. 10. 1 đ 2 (Ö, U), 2014. VI. 19. 1 ㅇ (Ö, U); Vízvár, Dráva 1999. VII. 31.1 đ 1 (N, U), 2001. VI. 8.1 


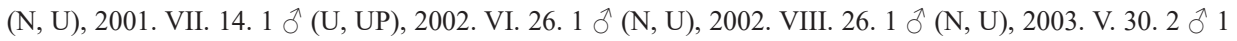

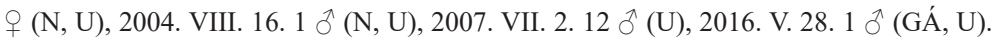

Oecetis testacea (Curtis, 1834) - Csesztreg-Kerkaújfalu (U 2004); Kercaszomor (U 2004); Magyarföld (U 2004); Magyarszombatfa (N 1985b, U \& N 1992a); Zalabaksa (U 2004).

Oecetis tripunctata (Fabricius, 1793) - Alsószenterzsébet (U 2004); Barcs, halastó (N 1985a); CsesztregKerkaújfalu (U 2004); Kercaszomor (U 2004); Magyarföld (U 2004); Magyarszombatfa (U \& N 1992a); Rédics, Kebele-p. (U 2004); Szentborbás (N \& U 1998) - Cserkút 2011. VI. 18.1 đ (U); Drávasztára 2004.

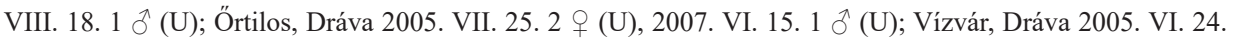
$3 \precsim(\mathrm{U}), 2007$. VII. 2. 5 $ぇ 16$ (U).

Setodes punctatus (Fabricius, 1793) - Alsószenterzsébet (U 2004); Babócsa, Rinya (N \& U 1998); Barcs, halastó (N 1985a); Cserkút (N et al. 1985); Barcs, halastó I. (N \& U 1998); Barcs, Kisbók (N \& U 1998); Barcs, szakiskola (N \& U 1998); Bélavár, Dráva (N \& U 1998); Bélavár, Lókai-mező (N \& U 1998); Csarnóta (N 2000); Csertő (N \& U 1990); Dobri (U 2004); Darány, Nagyberek (N \& U 1998); Diósviszló (N 2000); Drávapalkonya (N \& U 1995); Drávaszabolcs, Holt-Fekete-víz (N \& U 1998); Drávasztára (N \& U 1995, 1998); Felsőszentmárton, Korcsina-csat. (N \& U 1998); Gordisa, Mattyi-tó (N \& U 1995); Homokszentgyörgy (N \& U 1988); Kercaszomor (U 2004); Kerkaszentkirály, Kerka (U 2004); Kisdobsza (N \& U 1988); Kisharsány (N 2000); Komlósd (N \& U 1998); Magyarföld (U 2004); Magyarszombatfa (U \& N 1992a); Muraszemenye (U 2004); Örtilos, ártér (N \& U 1998); Örtilos, Dráva (N \& U 1995); Patosfa (N \& U 1990); Rédics, Kebele-p. (U 2004); Siklós, Göntér (N 2000); Somogyapáti (N \& U 1990); Szentborbás (U \& N 1992b, N \& U 1998); Szentlőrinc (N \& U 1990); Tótszerdahely (U 2004); Tótújfalu, Dráva (N \& U 1998); Vejti, Dráva (N \& U 1995, 1998); Vízvár, Dráva (N \& U 1995, 1998); Vízvár, község (N \& U 1995); Zákány (N \& U 1998) - Bélavár, Dráva 2002. VI. 18. 16 đ 3 (N, U), 2003. VI. 12. 4 đ 5 q (N, U); Darány, Nagyberek 1999. VII.

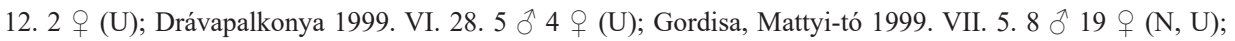
Gyékényes, Lankóci-e. 2001. VI. 9. 1 đ (U), 2003. VI. 17. 13 ð 12 ๑ (N, U); Ibafa, Gyürüfü 2007. VI. 22.1

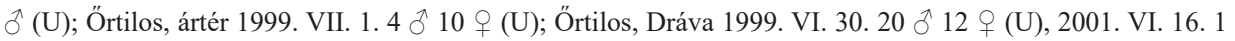

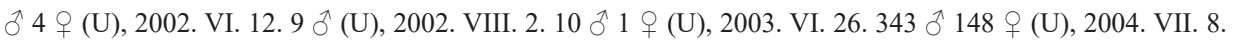

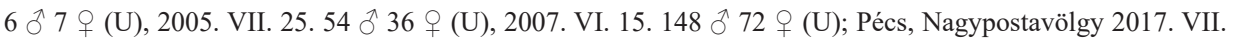
20. 1 q (GT); Siklós-Máriagyüd 2016. VI. 27. 2 ^ 3 q (N, U); Somogyudvarhely 1999. VIII. 4. 1 (U); Vízvár, Dráva 2001. VI. 8. 2 đ (N, U), 2001. VI. 25. 1 § (N, U), 2001. VII. 14. 116 đ 25 q (U, UP), 2001.

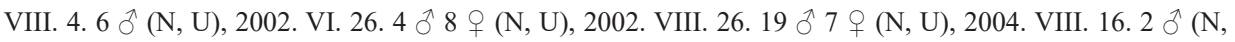

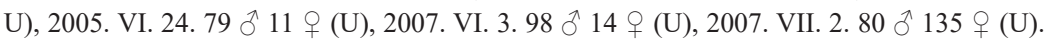

Setodes viridis (Fourcroy, 1785) - Kercaszomor (U 2004); Kerkaszentkirály, Kerka (U 2004); Magyarszombatfa (N 1985b, N \& U 1988, U \& N 1992a); Örtilos, ártér (U 2005).

Leptocerus interruptus (Fabricius, 1775) - Kercaszomor (U 2004); Magyarföld (U 2004).

Leptocerus tineiformis (Curtis, 1834) - Almamellék, Sas-rét (N \& U 1990); Babócsa, ártér (N \& U 1998); Barcs, halastó (N 1985a, N \& U 1995); Barcs, halastó I. (N \& U 1998); Barcs, Kisbók (N \& U 1998); Barcs, szakiskola (N \& U 1998); Bélavár, Dráva (N \& U 1998); Bélavár, Lókai-mező (N \& U 1998); Böhönye (N \& U 1992); Csertő (N \& U 1990); „Darány“ (Ujhelyi 1981a); Darány, Kuti-őrház (N \& U 1998); Darány, Nagyberek (N \& U 1995, 1998); Diósviszló (N 2000); Dobri (U 2004); Drávapalkonya (N \& U 1995); Drávaszabolcs, Holt-Fekete-víz (N \& U 1998); Drávasztára (N \& U 1995, 1998); Gordisa, Mattyi-tó (N \& U 1995); Gyékényes, kavicsbányató (N \& U 1995); Hetvehely, Bükkösdi-v. (U \& N 2006); Homokszentgyörgy (N \& U 1988); Kercaszomor (U 2004); Kerkaszentkirály, Kerka (U 2004); Kisdobsza (N et al. 1985, N \& U 1988); Kisszentmárton, Majláthpuszta (N \& U 1995); „Középrigóc“ (Ujhelyi 1981a); Magyarföld (U 2004); Magyarszombatfa (U \& N 1992a); Murarátka, Holt-Mura (U 2004); Muraszemenye (U 2004); Örtilos, Dráva (N \& U 1995); Patosfa (N \& U 1990); Pellérd, halastavak (U \& N 2006); Somogyapáti (N \& U 1990); Szaporca, Kisinci (N \& U 1998); Szentborbás (U \& N 1992b, N \& U 1998); Szentlőrinc (N \& U 1990); Szulimán (N \& U 1990); Tótújfalu, Dráva (N \& U 1998); Vejti, Dráva (N \& U 1995, 1998); Vízvár, Dráva (N \& U 1995); Zákány (N \& U 1998) - Almamellék, Almás-p. 1998. VII. 19. 2 đ̊ 23 q (U); Bakonya, Nagy-Rege

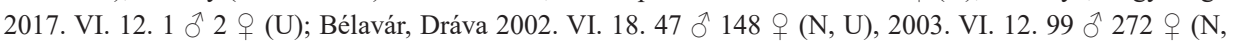
U); Bélavár, Lókai-mező 2001. VII. 9.166 đ 265 q (N, U), 2002. VI. 20. 685 ð̊ 925 q (U), 2004. VI. 18. 245 
đ 747 q (U); Cserkút 2011. VI. 18. 1 đ 3 q (U); Darány, Nagyberek 1999. VII. 12.7 q (U), 2000. VI. 6. 36 đ 288 q (N, U); Drávapalkonya 1999. VI. 28. 3 đ 9 q (U); Drávasztára 1999. VI. 12. 10 q (N, U), 2003. VI.

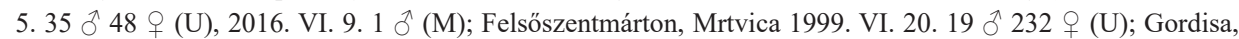
Mattyi-tó 1999. VII. 5. 2 đ 151 q (N, U), 2004. VI. 8.8 § 29 q (U); Gyékényes, Lankóci-e. 2000. V. 28. 21

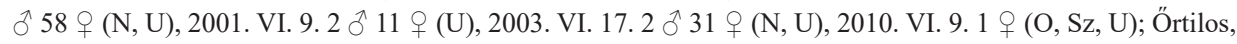

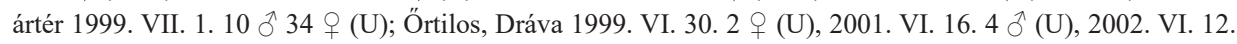
1 q (U), 2003. VI. 26. 1 q (U), 2004. VII. 8. 1 q (U); 2007. VI. 15. 1 § 3 q (U); Pécs, Nagypostavölgy 2017. VI. 1-2. 7 q (GT), 2017. VII. 10-18. 1 q (GT), 2018. V. 1-13. 1 q (GT), 2018. V. 28. 1 § 2 (GT); Somogyudvarhely 1999. VIII. 4. 1 \& (U); Szava, Szőlőhegy 2013. VII. 10. 1 đ̊ (Ö, U); Vízvár, Dráva 2001.

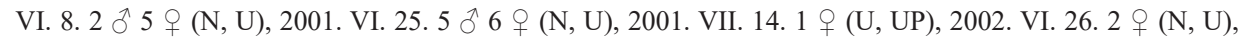
2003. V. 30. 1 (N, U), 2005. VI. 24. 2 穴 (U).

Adicella filicornis (Pictet, 1834) - Magyarszombatfa (U \& N 1992a) - Vízvár, Dráva 1999. VII. 31.2 q (N, U).

Adicella reducta (McLachlan, 1865) - Kercaszomor (U 2004).

Adicella syriaca Ulmer, 1907 - Kisdobsza (N 1986; N \& U 1988); Vízvár, Dráva (U 2005) - Bélavár, Dráva 2002. VI. 18. 2 q (N, U), 2003. VI. 12. 1 † (N, U); Bélavár, Lókai-mező 2004. VI. 18. 1 † (U); Darány, Nagyberek 2000. VI. 6. 2 ô 1 (N, U); Örtilos, Dráva 2001. VI. 16. 1 q (U); Vízvár, Dráva 2000. V. 25.4 우 (N, U), 2001. VI. 8. 2 § 13 (N, U), 2001. VI. 25. 3 q (N, U), 2001. VII. 14. 27 q (U, UP), 2001. VIII. 4.

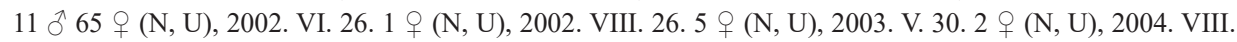
16. 81 q (N, U), 2005. VI. 24. 3 ^ 3 (U), 2006. VI. 13. 9 q (N, U), 2006. VIII. 17. 4 q (U), 2007. VI. 3. 1

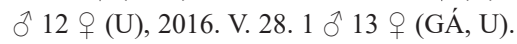

\section{Sericostomatidae}

Notidobia ciliaris (Linnaeus, 1761) - Bélavár, Almás-berek (N \& U 1998); Bélavár, Lókai-mező (N \& U 1998); Bükkösd, Gorica (N \& U 1990); Homokszentgyörgy (N \& U 1988); Komlósd (N \& U 1998); Magyarszombatfa (U \& N 1992a) - Bélavár, Almás-berek 2002. IV. 16. 1 đ̊ (U); Bélavár, Lókai-mező 1998.

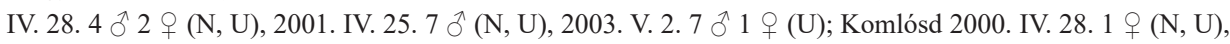
2002. IV. 16. 18 5 오 (N, U).

\section{Beraeidae}

Beraea pullata (Curtis, 1834) - Bükkösd, Korpád, Sormás-v. (N et al. 1985); Hetvehely, Bükkösdi-v. (U \& N 2006); Magyarszombatfa (U \& N 1992a); Pécs, Éger-v. (U \& N 2006); Somogyudvarhely, források (N \& U 1998) - Somogyudvarhely, források 1998. V. 22. 1 đ 1 q (N, U), 1998. VI. 10. 1 đ(U), 1999. V. 19. 2 đ 2 ㅇ (U), 2011. V. 19. 1 ઈे (O, U).

Beraeodes minutus (Linnaeus, 1761) - Bakonya, Sás-v. (U \& N 2006); Bükkösd, Korpád, Sormás-v. (N \& U 1990); Hetvehely, Káni-p. (N \& U 1990); Hetvehely, Nyáras-v. (U \& N 2006); Hetvehely, Sás-v. (U \& N 2006); Magyarszombatfa (U \& N 1992a).

Ernodes articularis (Pictet, 1834) - Somogyudvarhely, források (N \& U 1998) - Somogyudvarhely, forrá-

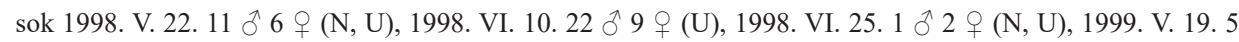

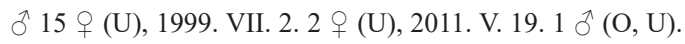

\section{Helicopsycidae}

Helicopsyche bacescui Orghidan \& Botosaneanu, 1953 - Somogyudvarhely, források (N \& U 1998) -

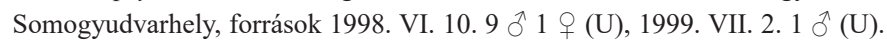




\section{Megvitatás}

\section{A tegzes fauna általános jellemzése}

A teljes hazai vízgyüjtőn az elmúlt mintegy negyven év alatt 143 faj került elő. A hazai fajok száma összesen 218 (v.ö. NóGRÁDI, UHERKOVICH 2002a), tehát a teljes hazai fauna 65,6\%-a itt is él, illetve néhány faj csak itt fordul elő. A mintákban található fajok illetve egyedek nagyobb része általánosan elterjedt, széles ökológiai türéshatárú, azaz sokféle vízben, gyengébb vízminőség mellett is tenyészhetnek. A ritkább fajok sokkal inkább egyes régiókhoz illetve bizonyos élőhely-típusokhoz kötöttek. A vízgyüjtő nyugati része - a Kerka és mellékvizeinek területe - a leggazdagabb fajokban. A fajok száma délkelet felé haladva általában csökken.

Jellegzetes élőhelyek (lásd a 2. táblázatot is!)

Dráva és Mura folyó. A vízgyüjtő két fő folyója közül a Dráva hazai viszonylatban a legtisztább nagy folyó, a Mura vízminősége az elmúlt egy-két évtizedben sokat javult. Számos olyan fajt mutattunk ki innét, amelyek a vízgyüjtő többi részén nem, vagy csak nagyon ritkán fordulnak elö. Ezek a gyorsabb folyású, kémiailag viszonylag tiszta, oxigénben dús vizek jellemző fajai. Magyarországon ezen kívül legfeljebb a kisebb-nagyobb folyók belépő szakasza mentén (Szigetköz, Felső-Tisza, Rába) vagy esetleg hegyvidéki patakokban élnek. A kérdéssel korábban részletesen foglalkoztunk (UHERKOVICH, NóGRÁDI 1997b). Ahogy lassul az áramlás sebessége és csökken az oxigén-tartalom, egyúttal a meder anyaga is változik, úgy már egyre több faj hiányzik közülük. Tipikusan ilyen fajok a Glossosoma boltoni, Agapetus ochripes, Polycentropus irroratus, Halesus radiatus, Platyphylax frauenfeldi, Chaetopteryx fusca, Silo nigricornis, Silo piceus, Athripsodes albifrons, Ylodes simulans, Erotesis baltica, Adicella filicornis, Adicella syriaca. Az erre a rész-tájra jellemző fajok mellett az általánosan elterjedt folyóvízi fajok is jelen vannak, és többnyire az utóbbiak közül kerülnek ki a domináns fajok (pl. Hydropsyche fajok, Goera pilosa, több Ceraclea és Oecetis faj, stb.).

Holtágak, bányatavak, halastavak. Míg a hazai állóvizek többsége - különösen a halastavak és egyéb mesterséges tavak - fajokban szegény, és gyakori fajaik euryök szervezetek, addig a vízgyüjtő állóvizeiben több ritka vagy jellemző faj fordul elő. A holtágak részben természetes lefüződéssel jöttek létre, részben pedig a folyószabályozás során keletkeztek. Vízjárásuk csak késve és csak részben követi a folyó vízjárását. Vízminőségük általában jó, bár az eutrofizáció elörehaladottabb állapotában lévő, sekély holtágak oldott oxigéntartalma erősen lecsökkenhet (pl. Bélavár, Lókai-mező; Felsőszentmárton, Mrtvica; Szaporca, Kisinci). Az aktív vagy egykori kavicsbányatavak vize ionszegény, alacsony $\mathrm{pH}$-jú, többnyire még a kitermelés befejezése után évtizedekkel is szegényes vegetációjú. Egyik jellemző tegzes fajuk az Oxyethira flavicornis. Csaknem minden állóvíz-típus domináns faja a Leptocerus tineiformis, mellette gyakoriak a Cercalea dissimilis, Ecnomus tenellus és az Oecetis-fajok. Több olyan faj is él ezekben - közülük némelyik a legnagyobb ritkaság -, amelyek az elmúlt évtizedekben megritkultak vagy eleve nagyon ritkák voltak: Agapetus delicatulus, Hydroptila dampfi, Hydroptila pulchricornis, Hydroptila occulta, Phryganea bipunctata, Micrasema setiferum, Ylodes kawraiskii. Közülük is ki kell emelnünk két fajt - Hydroptila pulchricornis és Micrasema setiferum -, amelyek eddig ismert egyetlen hazai példányai a Barcsi borókás elmocsarasadott halastava körül kerültek elö, még évtizedekkel ezelőtt. Jelen kori előfordulásukat nem sikerült bizonyítani. 
Lápok, mocsarak. Nagy kiterjedésű égerláp-erdő található Gyékényes határában, valamint több kisebb-nagyobb kiterjedésü lápfolt - közülük sok kiszáradóban van - a Barcsi borókás tarületén. A gyékényesi Lankóci-erdő és a darányi Nagyberek Tündérrózsás-tava rendszeres vizsgálataink tárgyát képezte, így faunájának összetétele elég jól ismert. Az általánosan elterjedt állóvízi fajok mellett kiemelkedően gyakori lehet a Trichostegia minor, ez mellett csak itt fordul vagy fordult elö a területen belül a Limnephilus stigma (Lankóci-erdő) és a Limnephilus subcentralis (Nagyberek). Elöbbi populációja napjainkban is viszonylag erős, az utóbbi faj több mint 30 éve megjelent (ezen kívül még Somogy 3 pontján), de a következő évben el is tünt (1987-1988). Nálunk csak a nyugati országrészben elterjedt és gyakori a Rhadicoleptus alpestris, de igen ritkán elöfordul itt is. Az utóbbi évtizedek kiszáradási folyamata sajnos ezeket a lápokat sem kerülte el, ami a tegzes-együttesek elszegényedésével járt együtt.

Oligotróf források. Egészen sajátos a somogyi homoktakaró tövében fakadó ionszegény oligotróf források tegzes együttese. Ez tipikus formájában Somogyudvarhelyen jelent meg, ott is elsősorban az egykori szeszfőzde alatti források körül, ahol mindössze 6 fajt találtunk. Ezek közül viszont négy - egészen egyedülálló módon - a környéken sehol sem él (Crunoecia irrorata, Helicopsyche bacescui, Ernodes articularis, Beraea pullata), míg két további faj (Lype reducta, Plectrocnemia conspersa) a környéken itt-ott ugyan elöfordulhat kisebb patakok vagy éppen a Dráva mentén, de nagyon ritkák. Berzence mellett ugyancsak van néhány ehhez hasonló forrás, de ott eddig csak a Crunoecia irrorata került elö. A felsorolt fajok többnyire nappali aktivitást mutatnak, ezért a források körül a nappali hálózások voltak eredményesek, éjjeli (hordozható fénycsapdával történő) gyüjtés nem hozott számottevő eredményt.

A határfolyók bal parti mellékvizei. A somogyi-baranyai területek mellékvizei fajokban sokkal szegényebbek, bár a potenciális fajgazdagság ezeknél sem kizárt (pl. Nyugati-Gyöngyös, 64 faj, vö. NóGRÁDI, UHERKOVICH 1988), itt is előfordulhatnak ritka vagy nagyon szórványos elterjedésü fajok (Orthotrichia angustella, Ithytrichia lamellaris, Hydroptila tineoides, Limnephilus xanthodes, Adicella syriaca). Sajnos, a mezőgazdasági területekről beszürődő mütrágya maradékok és az illegális szennyvíz-elhelyezések nagyon sokat rontanak állapotukon, és természetesen tegzes együtteseik értékén is. Ezért többségük fajszegény, csak a szélesebb ökológiai türéshatárú fajok élték túl a meder szabályozását és a vízminőség megváltozását (romlását).

Mecsek és Dél-Zselic vizei. Csak néhány rövidebb dombvidéki illetve alacsony hegyvidéki patakszakasz tartozik ide. Ezek medre itt-ott köves, kavicsos, másutt iszaposagyagos. Néhány faj sokkal inkább ezekre a vízfolyásokra jellemző, mint a vízgyüjtő többi területére (Wormaldia occipitalis, Plectrocnemia brevis, Tinodes pallidulus, Tinodes unicolor, Micropterna nycterobia, Beraeodes minutus). Csak itt fordul elö a Rhycophila hirticornis (Pécs, Éger-völgy). Összeségükben a vízgyüjtőnek csak igen kicsi részét képviselik, és alacsony fajszám jellemző rájuk.

Kerka és mellékvizei. Többféle karaterü vízfolyás tartozik ebbe a csoportba. A Vas és Zala megyék területén fekvő dombvidéki, tiszta vízű patakok (pl. Szentgyörgyvölgyipatak, Kerca) és kisebb folyók (pl. Kerka) meröben különböznek a somogyi és baranyai, csaknem sík térszíneken futó, sokkal szennyezettebb, iszapos medrü patakoktól. E dombvidéki patakok medre sok esetben kavicsos ágyú; helyenként lápos területeket szelnek át vagy azokkal közvetlenül határosak. Csak helyenként szabályozták medrüket, rövid idő alatt ezek a szabályozott szakaszok részben visszanyerik eredeti karaterüket. 
Fajokban igen gazdagok, köztük több olyan fajjal, amelyek csaknem kizárólag vagy kizárólag itt élnek (Glossosoma boltoni, Glossosoma conformis, Agapetus delicatulus, Hydroptila occulta, Hydroptila tineoides, Allotrichia pallicornis, Plectrocnemia brevis, Polycentropus flavomaculatus, Polycentropus irroratus, Phryganea bipunctata, Oligotricha striata, Limnephilus elegans, Rhadicoleptus alpestris, Halesus digitatus, Micropterna testacea, Lepidostoma hirtum, Athripsodes albifrons, Athripsodes bilineatus, Ylodes simulans, Oecetis testacea, Leptocerus interruptus, Adicella filicornis, Adicella reducta, Setodes viridis). Ezek közül a kisebb vízfolyások közül nagyon alaposan vizsgáltuk korábban - mintegy 30 éve - a Szentgyörgyvölgyi-patakot, amely fajgazdagsága országosan is egyedülálló: 100 fajt mutattunk ki Magyarszombatfánál, csaknem az összes fenti felsorolt érdekesebb fajt is (UHERKovich, NóGrádi 1992a). Hasonlóan értékes lehet a Kerca felső szakasza, ahol ugyancsak nagyon fajgazdag - bár még nem eléggé alaposan kikutatott - tegzes-együttesre leltünk, bizonyos, Magyarországon ritka fajok jelentős dominanciájával (Leptocerus interruptus, Setodes viridis, Oecetis testacea). A Zalai-dombságon, a vízrendszerhez tartozó vízfolyások itt-ott szintén meglehetôsen gazdagok, például a Ptatyphylax frauenfeldi jelentősebb populációjával (Szentpéterfölde).

\section{Természetvédelem}

\section{Unikális elöfordulások, ritkaságok}

Hydroptila pulchricornis (Pictet, 1834). Eddig ismert egyetlen példányát BarcsKözéprigócon, az erősen eutrofizálódott, nagyon nagy fajdiverzitású egykori I. halastónál fogtuk 1997. július 24-én, az eredeti jegyzőkönyvi feljegyzések szerint. (Mindkét rá vonatkozó irodalmi forrás - NóGRÁDI, UHERKOVICH 1998, NóGráDI 2001 - tévesen július 23-i dátumot közöl.) Ennek a fajnak azóta sem tudunk hazai példányáról, tehát unikális előfordulású.

A Micrasema setiferum Pictet 1834 fajnak ugyancsak egyetlen példányát ismerjük, ezt pontosan az előzőekben említett faj lelőhelyén, 1983. május 4-én fogtunk fényen (NóGRÁDI 1985a, 1985b). Azóta ennek sem került elő egyetlen példánya az ország egész területén. Lehetséges, hogy ez inkább nappal aktív állat, és fényen csak kivételesen jelenik meg? Rokon fajai terep-tapasztalataink szerint inkább nappali aktivitást mutatnak (Micrasema minimum - nálunk nem él -, és Brachycentrus subnubilus).

A Helicopsyche bacescui Orghidan \& Botoşăneanu 1953 erősen izolált előfordulásának felfedezése nagy meglepetésnek számított 1997-ben (NóGRÁDI 1998; NóGRÁDI, UHERKOVICH 1998). Somogyudvarhely község északi vége körül a somogyi homoktakaró meredeken szakad le az egykori ártérre. Évszázadokkal vagy évezredekkel ezelőtt a Dráva mosta alá, mára a meredek lejtő részben még áll, tövében legalább 10-12 kisebb-nagyobb ionszegény, tiszta vizü forrás fakad. Ezek és lefolyójuk körül több helyen is gyüjtöttük a faj példányait. A kísérő fajok is érdekesek: a Dráva mentén csakis itt fordul elö a Crunoecia irrorata (Curtis, 1834), az Ernodes articularis (Pictet, 1834) és a Beraea pullata (Curtis, 1834). Sajnos, időközben a források egy részét bekerítették és így megközelíthetetlenné váltak, emellett a terület egy részén leirtották a növényzetet. Így a populáció egy része eltünt vagy károsodott. A források a nemzeti park területén kívül fekszenek, így védelmükben egyelőre nem lehetett hatékony intézkedést tenni. Az állományt az elmúlt 15 évben nem tudtuk ellenőrizni, de kívánatos lenne a későbbiekben itt megfigyeléseket és gyüjtéseket végezni. Ettől északra, Berzence körül is van néhány hasonló forrás, de ott sem ezt, sem a kíséretében előforduló legtöbb fajt nem találtuk meg. 
Limnephilus stigma Curtis, 1834. A fajt korábban nem közölték Magyarországról. Egy régebbi, korábban publikálatlan példánya került elő Jósvafőről (NóGRÁDI et al. 1998), majd a kilencvenes évek közepén csaknem egyszerre fogták a Zempléni-hegységben (Füzér, László-tanya, 1995. VI. 15., leg. Papp Viktor Gábor) és a gyékényesi Lankócierdőben. Utóbbi helyen azóta is rendszeresen előfordul, néha nagyobb egyszámban. Például 2004. VI. 6-án 20 đ̂́ és 14 ㅇ példányt (leg. Uherkovich Á.), míg 2010. VI. 9-én 74 ô és 60 平 példányt (leg. Oláh J., Szivák I., Uherkovich Á.) fogtunk.

Limnephilus subcentralis Brauer, 1857. Érdekes ennek a fajnak az adatsora: bár négy helyről került elő Somogy megye területén, az összes példányt az 1987-88. években gyüjtöttük (NóGRÁDI 1992). Ezeken a helyeken elötte is, utána is sokszor gyüjtöttünk, de további példányokat nem láttunk. Ez mellett az Ujhelyi-féle tegzes-gyüjtemény revíziója során NóGRÁDI (1995) egy régebbi soproni egyedét is találta, ez addig közöletlen volt.

A Limnephilus elegans Curtis, 1834 „klasszikus” hazai lelőhelye Magyarszombatfa, ahonnét először UJHELYI (1981) közölte, mi fénycsapdával és személyes gyüjtésekkel számos további példányát fogtuk a nyolcvanas években (UHERKOVICH, NóGRÁDI 1992). Ezek mellett a Zselicből (NóGRÁDI, UHERKOVICH 1990) és a Szigetközből (UHERKOVICH, NóGRÁDI 1991) is előkerült. Az utóbbi években a fenti helyeken nem gyüjtöttünk, másutt nem kerültek elő további példányai. Sajnos, első, leggazdagabb lelőhelye nagymértékben degradálódott, a lelőhely közelében lévő láp illetve láprét erősen kiszáradt, a patakmedret sokfelé szabályozták. Ottani, jelen állapotát rendszeres terepmunkával lehetne megfigyelni.

Az Erotesis baltica McLachlan, 1877 országszerte hat helyről volt ismert (NóGRÁDI, UHERKOVICH 2002). Nagyon ritka, hiszen mindenhol csak egy-egy példányát gyüjtöttük. A Dráva menti kutatások viszonylag késői szakaszában fogtuk Vízváron (2006. május 22. $1 \overbrace{}^{\Uparrow}$ ), tehát ez a hetedik hazai lelőhelye és hetedik ismert példánya.

\section{Védett és védelemre szoruló fajok}

A két, fokozottan védett hazai faj közül az egyik, a Platyphylax frauenfeldi Brauer, 1857 a Dráva mentén több helyen, több alkalommal elökerült, bár éppen az utóbbi másfél évtizedben egyetlen példányát sem fogtuk. Első példányait a hetvenes évek végén gyüjtötték, ezeket az adatokat UjHELYI (1981a, 1981b) közölte. Később a Dráva mentén több helyről, beleértve a vízgyüjtő többi részét is, valamint a Zselic két pontjáról került elő (UHERKOvich, NóGRÁdi 1997a). A nyolcvanas, kilencvenes évektől az ezredfordulóig többfelé észleltük, egyes helyeken gyakorinak tünt (Szentborbás, Örtilos, Vízvár). 2000-ben, a Vízvárnál illetve Örtiloson gyüjtött imágók pároztatása után sikerült egy teljes életcikluson át felnevelni egy újabb nemzedéket, és ez alatt megismerni a fejlődési alakokat, illetve azok életmódját, táplálkozását (MALICKY et al. 2002). Fokozottan védett faj, $100000 \mathrm{Ft}$ a természetvédelmi értéke.

A védett fajok közé sorolják az elöbb már tárgyalt Limnephilus elegans Curtis, 1834, valamint a vízgyüjtő területén egykor nem ritka Oligotricha striata (Linnaeus, 1758) fajt. Mindkettő megritkult vagy talán el is tünt az elmúlt két évtizedben.

Ugyancsak a védett fajok közé tartozik a Rhyacophila hirticornis McLachlan, 1879, amely a drávai vízgyüjtő mecseki területének egyik kisebb vízfolyásában él, a pécsi Éger-völgyben. Itt egészen az utóbbi időkig szép állománya tenyészett. Ez a faj ezen kívül megtalálható még a Mecsek néhány további pontján, valamint a Kőszegihegységből és Zalaszántóról is vannak adatai (NóGRÁDI, UHERKOVICH 2002). Kis, elszigetelt, sérülékeny populációi minden bizonnyal erősen veszélyeztetettek.

A hazai tegzes faunának összesen csak 10 faja került fel a védettségi listákra. A fajok veszélyeztetettségét tekintve meglehetősen hosszú listát lehetett összeállítani ilyen szempontok alapján. A 20 éve elkészült veszélyeztetettségi lista (NóGRÁDI, UHERKOVICH 
1999) most is megállja a helyét, bár az „eltűnt” kategóriába azóta újabb fajokat is fel lehetne venni, hiszen némelyik 30-50 éve nem került elő.

Valójában több tucat olyan faj él nálunk, amely ritkasága, elszigetelt előfordulása vagy különleges élőhelyi igényei (ez miatti ritkasága) okán bekerülhetne a védett fajok körébe. Például a somogyudvarhelyi források jellemző elemei közül 3-4 fajnak (Helicopsyche bacescui, Ernodes articularis, Crunoecia irrorata és esetleg Beraea pullata) ott lenne a helye. A Micrasema setiferum egyetlen, nyolcvanas évekből származó bizonyítópéldánya inkább arra utalhat, hogy a faj eltünt, vagy pedig az eltünés határán van. Ugyanez mondható el a szintén unikális előfordulású Hydroptila pulchricornisról.

\section{Összefoglaló}

Szerzők a nyolcvanas évektől mostanáig rendszeresen és időnként igen nagy intenzitással kutatták a Dráva hazai vízrendszerének területén a tegzeseket. Összesen 179 lelöhely-csoportban (mintegy 270 lelöhelyen) több százezer tegzes imágót gyüjtöttek, és határozták meg azokat. Munkájuk eredményeképpen 143 faj előfordulása vált ismertté innét. A Dráva és Mura mentén 98 faj él eddigi ismereink szerint, míg a vízgyüjtő leggazdagabb részén, a Kerka és mellékvizei területén 108 faj vált ismertté.

Számos faj első hazai példányai innét kerültek elő. Két faj, a Micrasema setiferum (Pictet, 1834) és a Hydroptila pulchricornis Pictet, 1834 egyetlen ismert hazai példánya innét származik. Ugyancsak a vízgyüjtőn élt (vagy él még ma is) a Helicopsyche bacescui Orghidan \& Botosaneanu, 1953.

A fokozottan védett és Európában másutt mára eltünt Platyphylax frauenfeldi Brauer, 1857 erős populációja vált ismertté a Dráva és a Mura vízrendszeréből, a valaha gyüjtött példányok túlnyomó hányadát itt fogták. További három másik védett tegzes faj is előfordul a területen: Limnephilus elegans Curtis, 1834, Oligotricha striata (Linnaeus, 1758) és Rhyacophila hirticornis McLachlan, 1879. Igen sok olyan további fajt lehetne felsorolni, amelyek országszerte nagyon ritkák vagy nagyon szórványos elterjedésüek, és itt előfordulnak, több esetben erős, stabil populáció formájában.Több faj megritkult elmúlt közel négy évtized folyamán (pl. Limnephilus elegans Curtis, 1834, Oligotricha striata (Linnaeus, 1758 stb.), vagy populációja jelenleg lappangó fázisban van, mint például a Platyphylax frauenfeldi Brauer, 1857 esetében.

A Helicopsyche bacescui Orghidan \& Botosaneanu, 1953 egyetlen ismert hazai populációja közvetlenül veszélyeztetett, a kihalás szélére kerülhetett.

Némelyik, korábban közönséges, domináns vagy szubdomináns faj - mint például a Hydropsyche contubernalis McLachlan, 1865 - napjainkra nagyon megritkult. Ezzel szemben néhány más faj megjelent és ma már nem ritka, pl. Agapetus laniger (Pictet, 1834), Adicella syriaca Ulmer, 1907 stb. Összeségében azonban inkább a fauna elszegényedése (fajok számának csökkenése) a jellemző.

\section{Köszönetnyilvánítás}

Köszönetünket fejezzük ki mindazoknak, akik munkánkat segítették. A Duna-Dráva Nemzeti Park két munkatársa - Gáborik Ákos és Molnár Dániel - részben együtt, részben külön-külön több mintát vettek a Dráva mentén és bocsátottak rendelkezésünkre. A Dráva menti gyüjtésekben ugyancsak részt vett Szivák Ildikó és Móra Arnold, az általuk 
gyüjtött anyag adatait is felhasználhattam. Gergely Tibor az utóbbi néhány évben részben az egyik szerzővel együtt, részben önállóan mecseki és pécsi gyüjtéseket folytatott, az általa gyüjtött tegzeseket feldolgozásra és publikálásra átadta. Korábbi munkáinkat a most felsoroltakon kívül sokan segítették, az idézett cikkekben ezekre történik utalás. Az Árpádtetői Erdészet úthasználati engedéllyel segítette mecseki gyüjtőpontjaink megközelítését, amelyet itt is meg kell köszönnünk.

\section{1. táblázat: Gyűjtőhelyek (vagy lelőhely-csoportok), zónabeosztás** (lásd 2. táblá- zatot is), koordináták, UTM hálónégyzetek $(10 \times 10 \mathrm{~km})$ azonosítói, lelőhelyek száma (ha egynél több) és citációk a lelőhelyre.}

**zónák: 1 = élő Dráva és Mura; 2 = Dráva menti holtágak és bányatavak; 3 = Lápok, mocsarak (Darány, Gyékényes); $3 \mathrm{a}=$ Somogyudvarhely környéki források; 4 = Dráva balparti mellékvizei Somogyban és Baranyában (kivéve: 5 alattiak); 5 = Mecsek és Dél-Zselic kisebb patakjai; $6=$ Kerka és mellékvizei (Zala és Vas megye) - A koordinátákat a legközelebbi fokpercre kerekítettem. - A citációban szereplő rövidítések: $\mathrm{N}=$ Nógrádi S., U = Uherkovich Á.

Table 1: Collecting sites (or group of sites), zonation**

(see also Table 2), their coordinates,

UTM grid $(10 \times 10 \mathrm{~km})$, number of sites (if more than 1) in it and citation(s) for that sites.

**zones: 1 = Drava and Mura river; 2 = Oxbow lakes and gravel pits along Dráva; 3 = Moors, bogs (Darány, Gyékényes; $3 \mathrm{a}=$ springs around Somogyudvarhely; $4=$ Tributaries along the left side of Dráva in countries Baranya and Somogy (excl. under 5); $5=$ Small brooks of Mecsek Mts. and South-Zselic downs; $6=$ Kerka and its tributaries (countries Zala and Vas). - Coordinates are rounded up the next minute. - Abbreviations in citations: $\mathrm{N}=$ Nógrádi S., $\mathrm{U}=$ Uherkovich Á.

\begin{tabular}{|c|c|c|c|c|c|c|c|}
\hline No. & Localities & $\begin{array}{l}\text { zone } \\
* *\end{array}$ & $\begin{array}{l}\text { latit. } \\
\text { N }\end{array}$ & $\begin{array}{l}\text { longt. } \\
\text { E }\end{array}$ & $\begin{array}{l}\text { UTM } \\
\text { grid }\end{array}$ & $\begin{array}{l}\text { no. } \\
\text { of } \\
\text { sites }\end{array}$ & citation(s) \\
\hline 1 & Abaliget, Nyáras-v. & 5 & $46^{\circ} 08^{\prime}$ & $18^{\circ} 05^{\prime}$ & BS71 & 2 & $\begin{array}{l}\text { N et al. 1985; } \\
\text { U, N } 2006\end{array}$ \\
\hline 2 & Abaliget, vasútállomás (erdészház) & 5 & $46^{\circ} 09^{\prime}$ & $18^{\circ} 05^{\prime}$ & BS71 & & U, N 2006 \\
\hline 3 & Almamellék, Almás-p. & 4 & $46^{\circ} 09^{\prime}$ & $17^{\circ} 53^{\prime}$ & YM21 & & \\
\hline 4 & Almamellék, Sasrét & 5 & $46^{\circ} 12^{\prime}$ & $17^{\circ} 54^{\prime}$ & YM22 & & $\begin{array}{l}\text { N et al. 1985; } \\
\text { N, U } 1990\end{array}$ \\
\hline 5 & Almamellék, Szentmártonpuszta & 4 & $46^{\circ} 10^{\prime}$ & $17^{\circ} 54^{\prime}$ & YM21 & & N, U 1990 \\
\hline 6 & Alsószenterzsébet & 6 & $46^{\circ} 45^{\prime}$ & $16^{\circ} 29^{\prime}$ & XM17 & & U 2004 \\
\hline 7 & Babarcszőlős & 4 & $45^{\circ} 54^{\prime}$ & $18^{\circ} 08^{\prime}$ & BR78 & & N 2000 \\
\hline 8 & Babócsa, ártér & 2 & $46^{\circ} 00^{\prime}$ & $17^{\circ} 19^{\prime}$ & XL89 & 3 & N, U 1998 \\
\hline 9 & Babócsa, Rinya & 4 & $46^{\circ} 02^{\prime}$ & $17^{\circ} 21^{\prime}$ & XM80 & 2 & $\begin{array}{l}\text { N, U 1995; } \\
1998\end{array}$ \\
\hline 10 & Bajánsenye & 6 & $46^{\circ} 48^{\prime}$ & $16^{\circ} 23^{\prime}$ & XM08 & & \\
\hline 11 & Bakóca, Nagymátépuszta & 5 & $46^{\circ} 11^{\prime}$ & $17^{\circ} 59^{\prime}$ & YM31 & 2 & \\
\hline 12 & Bakonya, erdészház & 5 & $46^{\circ} 06^{\prime}$ & $18^{\circ} 05^{\prime}$ & BS70 & & $\mathrm{N}$ et al. 1985 \\
\hline 13 & Bakonya, Nagy-Rege & 5 & $46^{\circ} 06^{\prime}$ & $18^{\circ} 04^{\prime}$ & $\mathrm{BS} 70$ & & \\
\hline
\end{tabular}




\begin{tabular}{|c|c|c|c|c|c|c|c|}
\hline No. & Localities & $\begin{array}{l}\text { zone } \\
* *\end{array}$ & $\begin{array}{l}\text { latit. } \\
\mathbf{N}\end{array}$ & $\begin{array}{l}\text { longt. } \\
\mathrm{E}\end{array}$ & $\begin{array}{l}\text { UTM } \\
\text { grid }\end{array}$ & $\begin{array}{l}\text { no. } \\
\text { of } \\
\text { sites }\end{array}$ & citation(s) \\
\hline 14 & Bakonya, Sás-v. & 5 & $46^{\circ} 07^{\prime}$ & $18^{\circ} 04^{\prime}$ & BS81 & 2 & $\begin{array}{l}\mathrm{N} \text { et al. 1985; } \\
\mathrm{U}, \mathrm{N} 2006\end{array}$ \\
\hline 15 & „Barcs“ & 4 & & & XL99 & & $\mathrm{N}$ et al. 1985 \\
\hline 16 & Barcs, Barcs-Komlósdi-Rinya & 4 & $45^{\circ} 57^{\prime}$ & $17^{\circ} 28^{\prime}$ & XL99 & & N, U 1998 \\
\hline 17 & Barcs, Csikota & 3 & $45^{\circ} 58^{\prime}$ & $17^{\circ} 34^{\prime}$ & XL99 & & N 1985a \\
\hline 18 & Barcs, Dráva & 1 & $45^{\circ} 57^{\prime}$ & $17^{\circ} 27^{\prime}$ & XL89 & 3 & $\begin{array}{l}\text { U, N 1995; } \\
1997 ; \text { N, U } \\
1998\end{array}$ \\
\hline 19 & Barcs, erdészet & 4 & $45^{\circ} 58^{\prime}$ & $17^{\circ} 32^{\prime}$ & XL99 & & $\begin{array}{l}\text { N 1985a; U, N } \\
1997\end{array}$ \\
\hline 20 & Barcs, erdészház & 4 & $45^{\circ} 58^{\prime}$ & $17^{\circ} 32^{\prime}$ & XL99 & & N 1985a \\
\hline 21 & Barcs, halastó & 4 & $45^{\circ} 59^{\prime}$ & $17^{\circ} 32^{\prime}$ & XL99 & 2 & $\begin{array}{l}\text { N 1985a; } \\
1986 ; \text { N, U } \\
1995 ; 1998\end{array}$ \\
\hline 22 & Barcs, halastó I. & 4 & $46^{\circ} 00^{\prime}$ & $17^{\circ} 32^{\prime}$ & XL99 & & N, U 1998 \\
\hline 23 & Barcs, Kis-Bók & 2 & $45^{\circ} 57^{\prime}$ & $17^{\circ} 31^{\prime}$ & XL99 & 2 & \\
\hline 24 & Barcs, Macsilla-domb & 4 & $45^{\circ} 58^{\prime}$ & $17^{\circ} 34^{\prime}$ & XL99 & & N, U 1998 \\
\hline 25 & Barcs, Rinya-Ó-Dráva & 2 & $45^{\circ} 58^{\prime}$ & $17^{\circ} 24^{\prime}$ & XL89 & 3 & N, U 1998 \\
\hline 26 & Barcs, szakiskola & 4 & $45^{\circ} 59^{\prime}$ & $17^{\circ} 31^{\prime}$ & XL99 & & N, U 1998 \\
\hline 27 & Barcs, Szilonics-puszta & 1 & $45^{\circ} 57^{\prime}$ & $17^{\circ} 23^{\prime}$ & XL89 & 2 & U, N 1997 \\
\hline 27 & Bélavár, Almás-berek & 4 & $46^{\circ} 08^{\prime}$ & $17^{\circ} 11^{\prime}$ & XM61 & & N, U 1998 \\
\hline 29 & Bélavár, Dráva & 1 & $46^{\circ} 07^{\prime}$ & $17^{\circ} 11^{\prime}$ & XM60 & 2 & U, N 1997 \\
\hline 30 & Bélavár, Kerék-hegy & 4 & $46^{\circ} 08^{\prime}$ & $17^{\circ} 13^{\prime}$ & XM71 & & N, U 1998 \\
\hline 31 & Bélavár, Lókai-mező & 4 & $46^{\circ} 07^{\prime}$ & $17^{\circ} 12^{\prime}$ & XM61 & 6 & N, U 1998 \\
\hline 32 & Belezna, Kakonyapuszta & 4 & $46^{\circ} 20^{\prime}$ & $16^{\circ} 53^{\prime}$ & XM43 & 2 & N, U 1998 \\
\hline 33 & Belezna, Mura & 1 & $46^{\circ} 20^{\prime}$ & $16^{\circ} 53^{\prime}$ & XM43 & & U 2004 \\
\hline 34 & Berzence, Dombó-csat. & 4 & $46^{\circ} 12^{\prime}$ & $17^{\circ} 08^{\prime}$ & XM61 & & N, U 1998 \\
\hline 35 & Berzence, források & $3 a$ & $46^{\circ} 12^{\prime}$ & $17^{\circ} 09^{\prime}$ & XM61 & 2 & N, U 1998 \\
\hline 36 & Berzence, kavicsbányatavak & 2 & $46^{\circ} 12^{\prime}$ & $17^{\circ} 07^{\prime}$ & XM61 & 3 & N, U 1998 \\
\hline 37 & Berzence, Tekeres-berki-p. & 4 & $46^{\circ} 12^{\prime}$ & $17^{\circ} 09^{\prime}$ & XM61 & & N, U 1998 \\
\hline 38 & Böhönye & 4 & $46^{\circ} 25^{\prime}$ & $17^{\circ} 26^{\prime}$ & XM84 & 2 & N, U 1992 \\
\hline 39 & Bükkösd, Bükkösdi-p. & 5 & $46^{\circ} 08^{\prime}$ & $18^{\circ} 01^{\prime}$ & BS71 & 2 & U, N 2006 \\
\hline 40 & Bükkösd, Gorica & 5 & $46^{\circ} 08^{\prime}$ & $17^{\circ} 59^{\prime}$ & YM31 & & $\begin{array}{l}\mathrm{N} \text { et al. } 1985 \text {; } \\
\mathrm{N}, \mathrm{U} 1990\end{array}$ \\
\hline 41 & Bükkösd, Korpád, Sormás-v. & 5 & $46^{\circ} 09^{\prime}$ & $17^{\circ} 58^{\prime}$ & YM21 & 2 & $\begin{array}{l}\mathrm{N} \text { et al. } 1985 \text {; } \\
\mathrm{N}, \mathrm{U} 1990\end{array}$ \\
\hline 42 & Bükkösd, Szentdomján & 5 & $46^{\circ} 06^{\prime}$ & $18^{\circ} 01^{\prime}$ & BS61 & 3 & U, N 2006 \\
\hline 43 & Csarnóta & 4 & $45^{\circ} 53^{\prime}$ & $18^{\circ} 13^{\prime}$ & BR88 & 2 & N 2000 \\
\hline 44 & Cserkút & 5 & $46^{\circ} 04^{\prime}$ & $18^{\circ} 08^{\prime}$ & BS70 & 5 & $\mathrm{~N}$ et al. 1985 \\
\hline 45 & Csertő & 4 & $46^{\circ} 05^{\prime}$ & $17^{\circ} 48^{\prime}$ & YM10 & & N, U 1990 \\
\hline
\end{tabular}




\begin{tabular}{|c|c|c|c|c|c|c|c|}
\hline No. & Localities & $\begin{array}{l}\text { zone } \\
* *\end{array}$ & $\begin{array}{l}\text { latit. } \\
\mathbf{N}\end{array}$ & $\begin{array}{l}\text { longt. } \\
\text { E }\end{array}$ & $\begin{array}{l}\text { UTM } \\
\text { grid }\end{array}$ & $\begin{array}{l}\text { no. } \\
\text { of } \\
\text { sites }\end{array}$ & citation(s) \\
\hline 46 & Csesztreg-Kerkaújfalu & 6 & $46^{\circ} 44^{\prime}$ & $16^{\circ} 31^{\prime}$ & XM17 & & $\begin{array}{l}\text { N, U 2002b; U } \\
2004\end{array}$ \\
\hline 47 & Csömödér & 6 & $46^{\circ} 36^{\prime}$ & $16^{\circ} 38^{\prime}$ & XM26 & & $\begin{array}{l}\text { N, U 2002b; U } \\
2004\end{array}$ \\
\hline 48 & Csörnyefölde & 1 & $46^{\circ} 29^{\prime}$ & $16^{\circ} 39^{\prime}$ & XM24 & & $\begin{array}{l}\mathrm{N} \text { et al. } 1985 \text {; } \\
\mathrm{N}, \mathrm{U} 2002 \mathrm{~b}\end{array}$ \\
\hline 49 & Csurgó & 4 & $46^{\circ} 16^{\prime}$ & $17^{\circ} 06^{\prime}$ & XM62 & & N, U 1998 \\
\hline 50 & „Darány“ & 3 & & & XL99 & & $\begin{array}{l}\text { Ujhelyi 1981a; } \\
\mathrm{N} \text { et al. } 1985\end{array}$ \\
\hline 51 & Darány, Kuti örház & 4 & $45^{\circ} 59^{\prime}$ & $17^{\circ} 33^{\prime}$ & XL99 & 3 & $\begin{array}{l}\text { N 1985a; N, U } \\
1998\end{array}$ \\
\hline 52 & Darány, Nagyberek & 3 & $46^{\circ} 00^{\prime}$ & $17^{\circ} 33^{\prime}$ & XL99 & 2 & $\begin{array}{l}\text { N 1992a; N, U } \\
1995 ; 1998\end{array}$ \\
\hline 53 & Darány, Szürühely-folyás & 3 & $46^{\circ} 00^{\prime}$ & $17^{\circ} 34^{\prime}$ & XL99 & & N 1985a \\
\hline 54 & Darány, temető & 4 & $45^{\circ} 59^{\prime}$ & $17^{\circ} 35^{\prime}$ & XL99 & & N 1985a \\
\hline 55 & Dinnyeberki & 5 & $46^{\circ} 06^{\prime}$ & $17^{\circ} 56^{\prime}$ & YM21 & & \\
\hline 56 & Diósviszló & 4 & $45^{\circ} 54^{\prime}$ & $18^{\circ} 09^{\prime}$ & BR78 & & N 2000 \\
\hline 57 & Dobri & 6 & $46^{\circ} 31^{\prime}$ & $16^{\circ} 34^{\prime}$ & $\mathrm{XM} 25$ & & $\begin{array}{l}\text { N, U 2002b; U } \\
2004\end{array}$ \\
\hline 58 & Drávapalkonya (Dráva) & 1 & $45^{\circ} 47^{\prime}$ & $18^{\circ} 12^{\prime}$ & BR87 & & N, U 1995 \\
\hline 59 & Drávaszabolcs, Holt-Fekete-víz & 4 & $45^{\circ} 57^{\prime}$ & $18^{\circ} 12^{\prime}$ & BR87 & & N, U 1998 \\
\hline 60 & Drávaszentes & 4 & $45^{\circ} 59^{\prime}$ & $17^{\circ} 25^{\prime}$ & XL89 & & N, U 1998 \\
\hline 61 & Drávaszentes, Ferenctelep & 4 & $45^{\circ} 59^{\prime}$ & $17^{\circ} 24^{\prime}$ & XL89 & & N, U 1998 \\
\hline 62 & Drávaszentes, Komlósdi-Rinya & 4 & $45^{\circ} 59^{\prime}$ & $17^{\circ} 25^{\prime}$ & XL89 & & N, U 1998 \\
\hline 63 & Drávasztára (Dráva) & 1 & $45^{\circ} 49^{\prime}$ & $17^{\circ} 50^{\prime}$ & YL17 & 4 & N, U 1995 \\
\hline 64 & Drávatamási & 1 & $45^{\circ} 56^{\prime}$ & $17^{\circ} 34^{\prime}$ & XL99 & & N, U 1995 \\
\hline 65 & Felsőszentmárton, Korcsina-csat. & 4 & $45^{\circ} 50^{\prime}$ & $17^{\circ} 45^{\prime}$ & YL18 & & N, U 1998 \\
\hline 66 & Felsőszentmárton, Mrtvica & 2 & $45^{\circ} 51^{\prime}$ & $17^{\circ} 42^{\prime}$ & YL08 & & N, U 1998 \\
\hline 67 & Gilvánfa, erdészház & 4 & $45^{\circ} 54^{\prime}$ & $17^{\circ} 57^{\prime}$ & YL28 & & $\mathrm{N}$ et al. 1985 \\
\hline 68 & Gordisa, Mattyi-tó & 2 & $45^{\circ} 48^{\prime}$ & $18^{\circ} 15^{\prime}$ & BR87 & & N, U 1995 \\
\hline 69 & Gyékényes, Dombó-csat. & 4 & $46^{\circ} 15^{\prime}$ & $17^{\circ} 01^{\prime}$ & XM52 & & N, U 1995 \\
\hline 70 & Gyékényes, kavicsbányató & 2 & $46^{\circ} 14^{\prime}$ & $17^{\circ} 00^{\prime}$ & XM52 & 2 & \\
\hline 71 & Gyékényes, Lankóci-erdő & 3 & $46^{\circ} 14^{\prime}$ & $17^{\circ} 03^{\prime}$ & XM52 & & \\
\hline 72 & Hedrehely & 4 & $46^{\circ} 12^{\prime}$ & $17^{\circ} 39^{\prime}$ & YM01 & & $\begin{array}{l}\text { N et al. 1985; } \\
\text { N, U } 1990\end{array}$ \\
\hline 73 & Hegyszentmárton & 4 & $45^{\circ} 54^{\prime}$ & $18^{\circ} 05^{\prime}$ & BR78 & & N 2000 \\
\hline 74 & Helesfa & 4 & $46^{\circ} 05^{\prime}$ & $17^{\circ} 59^{\prime}$ & YM30 & & N, U 1990 \\
\hline 75 & Hetvehely, Bükkösdi-v. & 5 & $46^{\circ} 07^{\prime}$ & $18^{\circ} 02^{\prime}$ & BS71 & 2 & $\begin{array}{l}\text { N, U 1990; U, } \\
\text { N } 2006\end{array}$ \\
\hline 76 & Hetvehely, Káni-p. & 5 & $46^{\circ} 08^{\prime}$ & $18^{\circ} 02^{\prime}$ & BS61 & & $\begin{array}{l}\text { N, U 1990; U, } \\
\text { N } 2006\end{array}$ \\
\hline
\end{tabular}




\begin{tabular}{|c|c|c|c|c|c|c|c|}
\hline No. & Localities & $\begin{array}{l}\text { zone } \\
* *\end{array}$ & $\begin{array}{l}\text { latit. } \\
\mathbf{N}\end{array}$ & $\begin{array}{l}\text { longt. } \\
\text { E }\end{array}$ & $\begin{array}{l}\text { UTM } \\
\text { grid }\end{array}$ & $\begin{array}{l}\text { no. } \\
\text { of } \\
\text { sites }\end{array}$ & citation(s) \\
\hline 77 & Hetvehely, Nyáras-v. & 5 & $46^{\circ} 08^{\prime}$ & $18^{\circ} 05^{\prime}$ & BS71 & 2 & $\begin{array}{l}\text { N et al. } 1985 \text {; } \\
\text { U, N } 2006\end{array}$ \\
\hline 78 & Hetvehely, Sás-v. & 5 & $46^{\circ} 07^{\prime}$ & $18^{\circ} 03^{\prime}$ & BS71 & 2 & U, N 2006 \\
\hline 79 & Heresznye & 1 & $46^{\circ} 03^{\prime}$ & $17^{\circ} 16^{\prime}$ & XM70 & 2 & N, U 1998 \\
\hline 80 & Hirics, Dráva & 1 & $45^{\circ} 47^{\prime}$ & $18^{\circ} 01^{\prime}$ & BR67 & & N, U 1998 \\
\hline 81 & Homokszentgyörgy & 4 & $46^{\circ} 07^{\prime}$ & $17^{\circ} 36^{\prime}$ & YM01 & & N, U 1988 \\
\hline 82 & Ibafa, Gyürüfü & 5 & $46^{\circ} 07^{\prime}$ & $17^{\circ} 56^{\prime}$ & YM21 & 4 & \\
\hline 83 & Iharos, Ágneslak & 4 & $46^{\circ} 20^{\prime}$ & $17^{\circ} 04^{\prime}$ & XM53 & & $\mathrm{N}$ et al. 1985 \\
\hline 84 & Kemse, Háromfa & 4 & $45^{\circ} 48^{\prime}$ & $17^{\circ} 54^{\prime}$ & YL27 & 2 & N, U 1995 \\
\hline 85 & Kercaszomor & 6 & $46^{\circ} 47^{\prime}$ & $16^{\circ} 22^{\prime}$ & XM08 & 3 & U 2004 \\
\hline 86 & Kerkaszentkirály, Kerka & 6 & $46^{\circ} 30^{\prime}$ & $16^{\circ} 35^{\prime}$ & XM25 & 2 & $\begin{array}{l}\text { N, U 2002b; U } \\
2004\end{array}$ \\
\hline 87 & $\begin{array}{l}\text { Kerkaszentmihály-Margitmajor, } \\
\text { Lendva }\end{array}$ & 6 & $46^{\circ} 29^{\prime}$ & $16^{\circ} 34^{\prime}$ & XM24 & & $\begin{array}{l}\text { N, U 2002b; U } \\
2004\end{array}$ \\
\hline 88 & Kerkateskánd & 6 & $46^{\circ} 34^{\prime}$ & $16^{\circ} 35^{\prime}$ & XM25 & & N, U 2002b \\
\hline 89 & Kisdobsza & 4 & $46^{\circ} 01^{\prime}$ & $17^{\circ} 39^{\prime}$ & YL09 & 3 & $\begin{array}{l}\text { N et al. 1985; } \\
\text { N 1986; N, U } \\
1988\end{array}$ \\
\hline 90 & Kisharsány & 4 & $45^{\circ} 52^{\prime}$ & $18^{\circ} 23^{\prime}$ & BR98 & & N 2000 \\
\hline 91 & Kisszentmárton, Dráva & 1 & $45^{\circ} 46^{\prime}$ & $18^{\circ} 03^{\prime}$ & BR77 & & N, U 1998 \\
\hline 92 & Kisszentmárton, Majláthpuszta & 2 & $45^{\circ} 47^{\prime}$ & $18^{\circ} 05^{\prime}$ & BR77 & & N, U 1995 \\
\hline 93 & Komlósd & 4 & $46^{\circ} 01^{\prime}$ & $17^{\circ} 23^{\prime}$ & XL89 & & $\begin{array}{l}\text { N et al. 1985; } \\
\text { N, U 1995; } \\
1998 ; \text { U } 2005\end{array}$ \\
\hline 94 & Kővágószőlős & 5 & $46^{\circ} 04^{\prime}$ & $18^{\circ} 06^{\prime}$ & BS70 & 3 & $\mathrm{~N}$ et al. 1985 \\
\hline 95 & Kővágószőlős, Jakab-h. & 5 & $46^{\circ} 06^{\prime}$ & $18^{\circ} 08^{\prime}$ & BS70 & & \\
\hline 96 & Kővágótöttös & 5 & $45^{\circ} 04^{\prime}$ & $18^{\circ} 05^{\prime}$ & BS70 & & \\
\hline 97 & Kővágótöttös, Cserma-h. & 5 & $46^{\circ} 07^{\prime}$ & $18^{\circ} 06^{\prime}$ & BS70 & 2 & \\
\hline 98 & „Középrigóc““ & 4 & $46^{\circ} 04^{\prime}$ & $18^{\circ} 06^{\prime}$ & XL99 & 3 & Ujhelyi 1981a \\
\hline 99 & Lad & 4 & $46^{\circ} 08^{\prime}$ & $1737^{\circ}$ & YM01 & & N, U 1990 \\
\hline 100 & Lenti, Bárszentmihályfa & 6 & $46^{\circ} 39^{\prime}$ & $16^{\circ} 34^{\prime}$ & XM26 & & $\begin{array}{l}\text { N, U 2002b; U } \\
2004\end{array}$ \\
\hline 101 & Lenti, Kerka & 6 & $46^{\circ} 38^{\prime}$ & $16^{\circ} 33^{\prime}$ & XM16 & & N, U 2002b \\
\hline 102 & Lenti, Sár-berki-p. & 6 & $46^{\circ} 38^{\prime}$ & $16^{\circ} 33^{\prime}$ & XM16 & & N, U 2002b \\
\hline 103 & Magyarföld & 6 & $46^{\circ} 47^{\prime}$ & $16^{\circ} 25^{\prime}$ & XM07 & & U 2004 \\
\hline 104 & Magyarszombatfa & 6 & $46^{\circ} 45^{\prime}$ & $16^{\circ} 21^{\prime}$ & XM07 & 2 & $\begin{array}{l}\text { U, N 1992a; } \\
1997\end{array}$ \\
\hline 105 & Matty, Keselyősfapuszta & 2 & $45^{\circ} 46^{\prime}$ & $18^{\circ} 17^{\prime}$ & BR87 & & $\begin{array}{l}\text { N, U 1995; } \\
1998\end{array}$ \\
\hline 106 & Mike & 4 & $46^{\circ} 14^{\prime}$ & $17^{\circ} 32^{\prime}$ & XM92 & 3 & $\mathrm{~N}$ et al. 1985 \\
\hline 107 & Mikekarácsonyfa, Kerta-p. & 6 & $46^{\circ} 40^{\prime}$ & $16^{\circ} 42^{\prime}$ & XM26 & & N, U 2002b \\
\hline
\end{tabular}




\begin{tabular}{|c|c|c|c|c|c|c|c|}
\hline No. & Localities & $\begin{array}{l}\text { zone } \\
* *\end{array}$ & $\begin{array}{l}\text { latit. } \\
\mathbf{N}\end{array}$ & $\begin{array}{l}\text { longt. } \\
\text { E }\end{array}$ & $\begin{array}{l}\text { UTM } \\
\text { grid }\end{array}$ & $\begin{array}{l}\text { no. } \\
\text { of } \\
\text { sites }\end{array}$ & citation(s) \\
\hline 108 & Murarátka, Holt-Mura & 2 & $46^{\circ} 27^{\prime}$ & $16^{\circ} 41^{\prime}$ & XM34 & & $\begin{array}{l}\text { N, U 2002b; U } \\
2004\end{array}$ \\
\hline 109 & Murarátka, Mura & 1 & $46^{\circ} 27^{\prime}$ & $16^{\circ} 41^{\prime}$ & XM34 & & $\begin{array}{l}\text { N, U 2002b; U } \\
2004\end{array}$ \\
\hline 110 & Muraszemenye & 1 & $46^{\circ} 28^{\prime}$ & $16^{\circ} 38^{\prime}$ & $\mathrm{XM} 24$ & 2 & $\begin{array}{l}\mathrm{N}, \mathrm{U} 2002 \mathrm{~b} ; \mathrm{U} \\
2004\end{array}$ \\
\hline 111 & $\begin{array}{l}\text { Muraszemenye, Csernec, Kerka- } \\
\text { torok }\end{array}$ & 1 & $46^{\circ} 28^{\prime}$ & $16^{\circ} 37^{\prime}$ & XM24 & & $\mathrm{N}, \mathrm{U} 2002 \mathrm{~b}$ \\
\hline 112 & Nagydobsza & 4 & $46^{\circ} 02^{\prime}$ & $17^{\circ} 40^{\prime}$ & YM01 & & N, U 1988 \\
\hline 113 & Nagyharsány & 4 & $45^{\circ} 51^{\prime}$ & $18^{\circ} 24^{\prime}$ & BR98 & 3 & \\
\hline 114 & Nemesnép & 6 & $46^{\circ} 42^{\prime}$ & $16^{\circ} 27^{\prime}$ & XM17 & & $\begin{array}{l}\text { N, U 2002b; U } \\
2004\end{array}$ \\
\hline 115 & Nova-Zágorhida, Cserta & 6 & $46^{\circ} 41^{\prime}$ & $16^{\circ} 42^{\prime}$ & XM37 & & U 2004 \\
\hline 116 & Ortaháza, Berek-p. & 6 & $46^{\circ} 38^{\prime}$ & $16^{\circ} 41^{\prime}$ & XM26 & & N, U 2002b \\
\hline 117 & Örtilos, ártér & 2 & $46^{\circ} 17^{\prime}$ & $16^{\circ} 54^{\prime}$ & XM42 & & $\begin{array}{l}\text { U, N 1995; } \\
1997\end{array}$ \\
\hline 118 & Örtilos, Dráva-part & 1 & $46^{\circ} 18^{\prime}$ & $16^{\circ} 53^{\prime}$ & XM42 & 3 & $\begin{array}{l}\text { U, N 1995; } \\
\text { 1997; U 2005 }\end{array}$ \\
\hline 119 & Örtilos, Új-Zrínyi-vár & 4 & $46^{\circ} 19^{\prime}$ & $16^{\circ} 53^{\prime}$ & XM43 & 3 & N, U 1998 \\
\hline 120 & Páka, Alsó-Válicka & 4 & $46^{\circ} 36^{\prime}$ & $16^{\circ} 38^{\prime}$ & XM35 & & N, U 2002b \\
\hline 121 & Patosfa & 4 & $46^{\circ} 07^{\prime}$ & $17^{\circ} 41^{\prime}$ & YM10 & & N, U 1990 \\
\hline 122 & Pécs, Deindol & 5 & $46^{\circ} 06^{\prime}$ & $18^{\circ} 12^{\prime}$ & BS80 & & U, N 2006 \\
\hline 123 & Pécs, Dömörkapu & 5 & $46^{\circ} 06^{\prime}$ & $18^{\circ} 14^{\prime}$ & BS80 & & $\begin{array}{l}\mathrm{N} \text { et al. } 1985 \text {; } \\
\mathrm{U}, \mathrm{N} 2006\end{array}$ \\
\hline 124 & Pécs, Éger-völgy & 5 & $46^{\circ} 06^{\prime}$ & $18^{\circ} 10^{\prime}$ & BS 80 & 8 & $\begin{array}{l}\text { N et al. } 1985 \\
\text { U, N } 2006\end{array}$ \\
\hline 125 & Pécs, Kertváros & 4 & $46^{\circ} 03^{\prime}$ & $18^{\circ} 13^{\prime}$ & BS80 & & $\mathrm{N}$ et al. 1985 \\
\hline 126 & Pécs, Lapis & 5 & $46^{\circ} 07^{\prime}$ & $18^{\circ} 12^{\prime}$ & BS80 & & $\mathrm{N}$ et al. 1985 \\
\hline 127 & Pécs, Mecsekszentkút, Szunyola & 5 & $46^{\circ} 06^{\prime}$ & $18^{\circ} 10^{\prime}$ & BS80 & 3 & \\
\hline 128 & Pécs, Misina & 5 & $46^{\circ} 06^{\prime}$ & $18^{\circ} 13^{\prime}$ & BS80 & & $\begin{array}{l}\text { N et al. } 1985 \\
\text { U, N } 2006\end{array}$ \\
\hline 129 & Pécs, Nagyárpád, Tüskés-rét & 4 & $46^{\circ} 02^{\prime}$ & $18^{\circ} 15^{\prime}$ & BS80 & & \\
\hline 130 & Pécs, Nagypostavölgy & 4 & $46^{\circ} 02^{\prime}$ & $18^{\circ} 14^{\prime}$ & BS80 & & \\
\hline 131 & Pécs, Tubes & 5 & $46^{\circ} 07^{\prime}$ & $18^{\circ} 12^{\prime}$ & BS80 & & $\mathrm{N}$ et al. 1985 \\
\hline 132 & Pécs, város & 4 & $46^{\circ} 04^{\prime}$ & $18^{\circ} 12^{\prime}$ & BS 80 & & U, N 2006 \\
\hline 133 & Pellérd (halastavak) & 4 & $46^{\circ} 03^{\prime}$ & $18^{\circ} 09^{\prime}$ & BS70 & & $\begin{array}{l}\mathrm{N} \text { et al. } 1985 \\
\mathrm{U}, \mathrm{N} 2006\end{array}$ \\
\hline 134 & Péterhida & 4 & $46^{\circ} 00^{\prime}$ & $17^{\circ} 22^{\prime}$ & XL89 & & N, U 1998 \\
\hline 135 & Porrogszentpál, Rigócz-p. & 4 & $46^{\circ} 18^{\prime}$ & $17^{\circ} 00^{\prime}$ & XM52 & & N, U 1998 \\
\hline 136 & Potony, Lugi-erdő & 4 & $45^{\circ} 55^{\prime}$ & $17^{\circ} 39^{\prime}$ & YL08 & & N, U 1995 \\
\hline 137 & Rédics, Kebele-p. & 6 & $46^{\circ} 37^{\prime}$ & $16^{\circ} 27^{\prime}$ & XM16 & & U 2004 \\
\hline
\end{tabular}




\begin{tabular}{|c|c|c|c|c|c|c|c|}
\hline No. & Localities & $\begin{array}{l}\text { zone } \\
* *\end{array}$ & $\begin{array}{l}\text { latit. } \\
\mathbf{N}\end{array}$ & $\begin{array}{l}\text { longt. } \\
\text { E }\end{array}$ & $\begin{array}{l}\text { UTM } \\
\text { grid }\end{array}$ & $\begin{array}{l}\text { no. } \\
\text { of } \\
\text { sites }\end{array}$ & citation(s) \\
\hline 138 & Resznek, Szentgyörgyvölgyi-p. & 6 & $46^{\circ} 40^{\prime}$ & $16^{\circ} 27^{\prime}$ & XM16 & & U 2004 \\
\hline 139 & Sellye & 4 & $45^{\circ} 53^{\prime}$ & $17^{\circ} 51^{\prime}$ & YL28 & 4 & $\mathrm{~N}$ et al. 1985 \\
\hline 140 & Siklós, Csukma-h. & 4 & $45^{\circ} 54^{\prime}$ & $18^{\circ} 17^{\prime}$ & BR98 & 2 & N 2000 \\
\hline 141 & Siklós, Göntér & 4 & $45^{\circ} 52^{\prime}$ & $18^{\circ} 20^{\prime}$ & BR98 & & N 2000 \\
\hline 142 & Siklós-Máriagyüd & 4 & $45^{\circ} 53^{\prime}$ & $18^{\circ} 16^{\prime}$ & BR88 & 2 & N 2000 \\
\hline 143 & Somogyapáti & 4 & $46^{\circ} 06^{\prime}$ & $17^{\circ} 45^{\prime}$ & YM10 & 2 & N, U 1990 \\
\hline 144 & Somogybükkösd & 4 & $46^{\circ} 18^{\prime}$ & $17^{\circ} 00^{\prime}$ & XM52 & & \\
\hline 145 & Somogyhatvan & 4 & $46^{\circ} 06^{\prime}$ & $17^{\circ} 43^{\prime}$ & YM10 & & N, U 1990 \\
\hline 146 & Somogyudvarhely & 4 & $46^{\circ} 11^{\prime}$ & $17^{\circ} 10^{\prime}$ & XM61 & 5 & $\mathrm{~N}$ et al. 1985 \\
\hline 147 & Somogyudvarhely, Dombó-csat. & 4 & $46^{\circ} 10^{\prime}$ & $17^{\circ} 11^{\prime}$ & XM61 & 3 & N, U 1998 \\
\hline 148 & Somogyudvarhely, források & $3 a$ & $46^{\circ} 11^{\prime}$ & $17^{\circ} 11^{\prime}$ & XM61 & 3 & N, U 1998 \\
\hline 149 & Sumony (halastavak) & 4 & $45^{\circ} 58^{\prime}$ & $17^{\circ} 53^{\prime}$ & YL29 & & U, N 1997 \\
\hline 150 & Szaporca, Kisinci & 2 & $45^{\circ} 57^{\prime}$ & $18^{\circ} 06^{\prime}$ & BR77 & & N, U 1998 \\
\hline 151 & Szava (Bostai-árok) & 4 & $45^{\circ} 54^{\prime}$ & $18^{\circ} 11^{\prime}$ & BR88 & & N 2000 \\
\hline 152 & Szava, Szőlőhegy & 4 & $45^{\circ} 53^{\prime}$ & $18^{\circ} 12^{\prime}$ & BR88 & & \\
\hline 153 & Szécsisziget, Petrócpuszta, Cserta & 6 & $46^{\circ} 34^{\prime}$ & $16^{\circ} 36^{\prime}$ & $\mathrm{XM} 25$ & & $\begin{array}{l}\text { N, U 2002b; U } \\
2004\end{array}$ \\
\hline 154 & Szentborbás (Dráva) & 1 & $45^{\circ} 52^{\prime}$ & $17^{\circ} 39^{\prime}$ & YL08 & & $\begin{array}{l}\text { N, U 1995; } \\
1998 ; U, N \\
1997\end{array}$ \\
\hline 155 & Szentgyörgyvölgy & 6 & $46^{\circ} 44^{\prime}$ & $16^{\circ} 25^{\prime}$ & XM07 & & U 2004 \\
\hline 156 & Szentlászló & 4 & $46^{\circ} 08^{\prime}$ & $17^{\circ} 50^{\prime}$ & YM11 & & $\begin{array}{l}\text { N et al. 1985; } \\
\text { N, U } 1990\end{array}$ \\
\hline 157 & Szentlőrinc (Bükkösdi-p.) & 4 & $46^{\circ} 03^{\prime}$ & $17^{\circ} 59^{\prime}$ & YM30 & 3 & $\begin{array}{l}\mathrm{N} \text { et al. } 1985 \\
\mathrm{~N}, \mathrm{U} 1990\end{array}$ \\
\hline 158 & Szentpéterfölde (erdészet) & 6 & $46^{\circ} 36^{\prime}$ & $16^{\circ} 45^{\prime}$ & XM36 & & $\begin{array}{l}\text { U, N 1997; N, } \\
\text { U 2002b }\end{array}$ \\
\hline 159 & Szulimán (Almás-p.) & 4 & $46^{\circ} 07^{\prime}$ & $17^{\circ} 49^{\prime}$ & YM11 & & $\begin{array}{l}\mathrm{N} \text { et al. } 1985 \\
\mathrm{~N}, \mathrm{U} 1990\end{array}$ \\
\hline 160 & Szulok (erdészház) & 4 & $46^{\circ} 03^{\prime}$ & $17^{\circ} 34^{\prime}$ & YM00 & & $\mathrm{N}$ et al. 1985 \\
\hline 161 & Tormafölde & 6 & $46^{\circ} 33^{\prime}$ & $16^{\circ} 36^{\prime}$ & XM25 & & $\begin{array}{l}\mathrm{N} \text { et al. 1985; } \\
\mathrm{N}, \mathrm{U} \text { 2002b; U } \\
2004\end{array}$ \\
\hline 162 & Tormafölde, Vétyemi-ősbükkös & 6 & $46^{\circ} 33^{\prime}$ & $16^{\circ} 38^{\prime}$ & XM25 & & $\mathrm{N}, \mathrm{U} 2002 \mathrm{~b}$ \\
\hline 163 & Tornyiszentmiklós, Ó-Lendva & 6 & $46^{\circ} 39^{\prime}$ & $16^{\circ} 33^{\prime}$ & XM15 & & $\mathrm{N}, \mathrm{U} 2002 \mathrm{~b}$ \\
\hline 164 & Tótszerdahely (Mura) & 1 & $46^{\circ} 23^{\prime}$ & $16^{\circ} 47^{\prime}$ & XM33 & & U 2004 \\
\hline 165 & Tótújfalu, Dráva & 1 & $45^{\circ} 54^{\prime}$ & $17^{\circ} 37^{\prime}$ & YL08 & 2 & N, U 1998 \\
\hline 166 & Tótújfalu, Lugi-e. & 4 & $45^{\circ} 54^{\prime}$ & $17^{\circ} 39^{\prime}$ & YL08 & & N, U 1998 \\
\hline 167 & Vásárosbéc (Dióspuszta) & 4 & $46^{\circ} 09^{\prime}$ & $17^{\circ} 44^{\prime}$ & YM11 & & $\mathrm{N}$ et al. 1985 \\
\hline 168 & Vejti (Dráva) & 1 & $45^{\circ} 48^{\prime}$ & $17^{\circ} 59^{\prime}$ & YL37 & & N, U 1995 \\
\hline
\end{tabular}




\begin{tabular}{|c|c|c|c|c|c|c|c|}
\hline No. & Localities & $\begin{array}{l}\text { zone } \\
* *\end{array}$ & $\begin{array}{l}\text { latit. } \\
\mathbf{N}\end{array}$ & $\begin{array}{l}\text { longt. } \\
\text { E }\end{array}$ & $\begin{array}{l}\text { UTM } \\
\text { grid }\end{array}$ & $\begin{array}{l}\text { no. } \\
\text { of } \\
\text { sites }\end{array}$ & citation(s) \\
\hline 169 & Velemér & 6 & $46^{\circ} 44^{\prime}$ & $16^{\circ} 22^{\prime}$ & XM07 & & \\
\hline 170 & Vízvár, Dráva-part & 1 & $46^{\circ} 05^{\prime}$ & $17^{\circ} 13^{\prime}$ & XM70 & 4 & $\begin{array}{l}\text { N, U 1995; } \\
\text { 1998; U, N } \\
1997\end{array}$ \\
\hline 171 & Vízvár, község & 4 & $46^{\circ} 05^{\prime}$ & $17^{\circ} 14^{\prime}$ & XM70 & & N, U 1995 \\
\hline 172 & Vízvár, Vízház & 2 & $46^{\circ} 06^{\prime}$ & $17^{\circ} 13^{\prime}$ & XM70 & & N, U 1998 \\
\hline 173 & Zákány, Dráva holtág & 2 & $46^{\circ} 15^{\prime}$ & $16^{\circ} 56^{\prime}$ & XM52 & & U, N 1997 \\
\hline 174 & Zákány, Közép-hegyi-patak & 4 & $46^{\circ} 16^{\prime}$ & $16^{\circ} 53^{\prime}$ & XM52 & 3 & \\
\hline 175 & Zalabaksa & 6 & $46^{\circ} 42^{\prime}$ & $16^{\circ} 33^{\prime}$ & XM17 & & U 2004 \\
\hline 176 & Zaláta, Adravica & 2 & $45^{\circ} 47^{\prime}$ & $17^{\circ} 51^{\prime}$ & YL27 & & N, U 1998 \\
\hline 177 & Zaláta, Lajos-tanya & 4 & $45^{\circ} 47^{\prime}$ & $17^{\circ} 53^{\prime}$ & YL27 & & N, U 1995 \\
\hline 178 & Zaláta, rét & 4 & $45^{\circ} 48^{\prime}$ & $17^{\circ} 54^{\prime}$ & YL27 & & N, U 1995 \\
\hline 179 & Zebecke, Cserta-p. & 6 & $46^{\circ} 44^{\prime}$ & $16^{\circ} 22^{\prime}$ & XM07 & & $\mathrm{N}, \mathrm{U} 2002 \mathrm{~b}$ \\
\hline
\end{tabular}




\section{2. táblázat: A Dráva hazai vízgyüjtőjén előforduló tegzesek kistájak (t. k. víztípus-csoportok) szerint}

Table 2: Caddisflies occuring in the catchment area of Drava in Hungary by microregions

1 = Élő Dráva és Mura / Dráva and Mura, main branch

\section{(i. e. water types)}

2 = Dráva menti holtágak és bányatavak / Oxbow lakes and gravel pits along Dráva

3 = Lápok, mocsarak (Darány, Gyékényes) / Fens and moors (Darány, Gyékényes)

3a = Oligotróf források (Somogyudvarhely, Berzence) /Oligotrophic springs (Somogyudvarhely, Berzence)

4 = Dráva balparti mellékvizei Somogyban és Baranyában (kivéve: 5 alattiak) / Water courses along the left side in counties Somogy and Baranya (except under No 5)

5 = Mecsek és Dél-Zselic kisebb patakjai / Smaller brooks of the Mecsek Mts. and Zselic Downs

6 = Kerka és mellékvizei (Zala és Vas megye) / Kerka river and its tributaries (in counties Vas and Zala)

Gyakoriság / Frequency

Nincs észlelt előfordulás / No data

+ $\quad$ Egyetlen előfordulás (egyetlen vagy kevés - 2-3 - példány) / Single occurrence (single or a few specimens)

O Alkalmilag / Occasionally

- $\quad$ Rendszeresen, alacsony példányszámban / Regularly, but a few adults

- Rendszeresen, gyakori vagy tömeges / Regularly, frequent or in mass

\begin{tabular}{|c|c|c|c|c|c|c|c|}
\hline Faj neve /Species name & 1 & 2 & 3 & $3 \mathbf{a}$ & 4 & 5 & 6 \\
\hline Rhyacophila dorsalis & $\bullet$ & $\cdot$ & - & $\cdot$ & . & & \\
\hline Rhyacophila fasciata & . & . & . & . & $\bullet$ & - & - \\
\hline Rhyacophila hirticornis & . & . & . & . & . & $\bullet$ & . \\
\hline Rhyacophila pascoei & . & . & . & . & . & . & + \\
\hline Glossosoma boltoni & $\bullet$ & . & . & . & . & . & + \\
\hline Glossosoma conformis & . & . & . & . & . & . & + \\
\hline Agapetus delicatulus & . & . & + & . & . & . & + \\
\hline Agapetus laniger & $\bullet$ & . & $\bullet$ & . & . & . & $\bullet$ \\
\hline Agapetus ochripes & + & . & . & . & . & . & . \\
\hline Synagapetus mosely & . & . & . & . & . & $\bullet$ & . \\
\hline Orthotrichia angustella & $\bullet$ & $\bullet$ & $\bullet$ & . & $\bullet$ & & . \\
\hline Orthotrichia costalis & 0 & 0 & $\bullet$ & . & . & 0 & $\bullet$ \\
\hline Orthotrichia tragetti & 0 & O & $\bullet$ & . & & 0 & . \\
\hline Ithytrichia lamellaris & 0 & . & . & . & 0 & . & 0 \\
\hline Oxyethira falcata & 0 & & & . & 0 & O & 0 \\
\hline Oxyethira flavicornis & - & 0 & O & . & . & . & $\bullet$ \\
\hline Oxyethira tristella & $\bullet$ & . & . & . & & + & $\mathrm{O}$ \\
\hline Hydroptila angustipennis & $\bullet$ & . & & . & 0 & & 0 \\
\hline Hydroptila dampfi & . & & $\mathrm{O}$ & . & . & $\mathrm{O}$ & . \\
\hline Hydroptila forcipata & $\bullet$ & O & 0 & . & . & . & $\bullet$ \\
\hline Hydroptila lotensis & $\bullet$ & e & + & . & + & + & $\bullet$ \\
\hline Hydroptila occulta & . & . & + & . & . & . & 0 \\
\hline Hydroptila pulchricornis & $\dot{0}$ & & + & . & & . & . \\
\hline Hydroptila sparsa & O & $\bullet$ & $\bullet$ & . & $\mathrm{O}$ & $\bullet$ & - \\
\hline Hydroptila tineoides & & & . & . & + & . & . \\
\hline Hydroptila vectis & $\mathrm{O}$ & O & . & . & . & + & . \\
\hline Agraylea sexmaculata & $\bullet$ & $\bullet$ & $\bullet$ & . & $\bullet$ & + & $\bullet$ \\
\hline Allotrichia pallicornis & . & . & . & . & . & . & + \\
\hline Wormaldia occipitalis & . & . & . & . & . & $\bigcirc$ & . \\
\hline Hydropsyche angustipennis & $\bullet$ & & $\bullet$ & • & $\bullet$ & $\bullet$ & $\bullet$ \\
\hline Hydropsyche bulbifera & $\bullet$ & O & $\mathrm{O}$ & & 0 & + & $\bullet$ \\
\hline Hydropsyche bulgaromanorum & & & $\bullet$ & & & & $\bullet$ \\
\hline Hydropsyche contubernalis & & & O & . & & $\bullet$ & \\
\hline
\end{tabular}


Hydropsyche fulvipes Hydropsyche instabilis Hydropsyche modesta Hydropsyche ornatula Hydropsyche pellucidula Hydropsyche saxonica Hydropsyche siltalai Neureclipsis bimaculata Plectrocnemia brevis

Plectrocnemia conspersa

Polycentropus flavomaculatus Polycentropus irroratus Holocentropus dubius

Holocentropus picicornis

Holocentropus stagnalis

Cyrnus crenaticornis

Cyrnus trimaculatus

Psychomyia pusilla

Lype phaeopa

Lype reducta

Tinodes pallidulus

Tinodes unicolor

Ecnomus tenellus

Trichostegia minor

Agrypnia pagetana

Agrypnia varia

Phryganea bipunctata

Phryganea grandis

Oligotricha striata

Hagenella clathrata

Oligostomis reticulata

Brachycentrus subnubilus

Micrasema setiferum

Ironoquia dubia

Limnephilus affinis

Limnephilus auricula

Limnephilus bipunctatus

Limnephilus decipiens

Limnephilus elegans

Limnephilus extricatus

Limnephilus flavicornis

Limnephilus griseus

Limnephilus hirsutus

Limnephilus ignavus

Limnephilus incisus

Limnephilus lunatus

Limnephilus rhombicus

Limnephilus sparsus

Limnephilus stigma

Limnephilus subcentralis

Limnephilus vittatus

Limnephilus xanthodes

Grammotaulius nigropunctatus

Glyphotaelius pellucidus

Anabolia brevipennis

Anabolia furcata

Rhadicoleptus alpestris

Potamophylax luctuosus

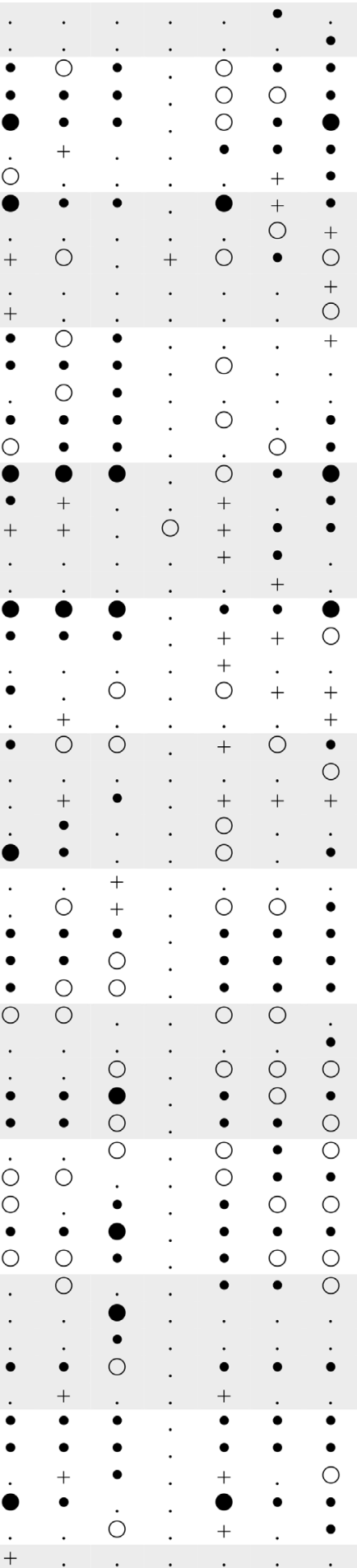


Potamophylax nigricornis Potamophylax rotundipennis Halesus digitatus Halesus radiatus Halesus tesselatus Platyphylax frauenfeldi

Stenophylax meridiorientalis

Stenophylax permistus

Micropterna lateralis

Micropterna nycterobia

Micropterna sequax

Micropterna testacea

Chaetopteryx fusca

Chaetopteryx major

Goera pilosa

Lithax obscurus

Silo nigricornis

Silo pallipes

Silo piceus

Lepidostoma hirtum

Crunoecia irrorata

Athripsodes albifrons

Athripsodes aterrimus

Athripsodes bilineatus

Athripsodes cinereus

Ceraclea alboguttata

Ceraclea annulicornis

Ceraclea aurea

Ceraclea dissimilis

Ceraclea fulva

Ceraclea riparia

Ceraclea senilis

Mystacides azurea

Mystacides longicornis

Mystacides nigra

Triaenodes bicolor

Ylodes kawraiskii

Ylodes simulans

Erotesis baltica

Oecetis furva

Oecetis lacustris

Oecetis notata

Oecetis ochracea

Oecetis testacea

Oecetis tripunctata

Setodes punctatus

Setodes viridis

Leptocerus interruptus

Leptocerus tineiformis

Adicella filicornis

Adicella reducta

Adicella syriaca

Notidobia ciliaris

Beraea pullata

Beraeodes minutus

Ernodes articularis

Helicopsyche bacescui

összesen/altogether 143 faj/species

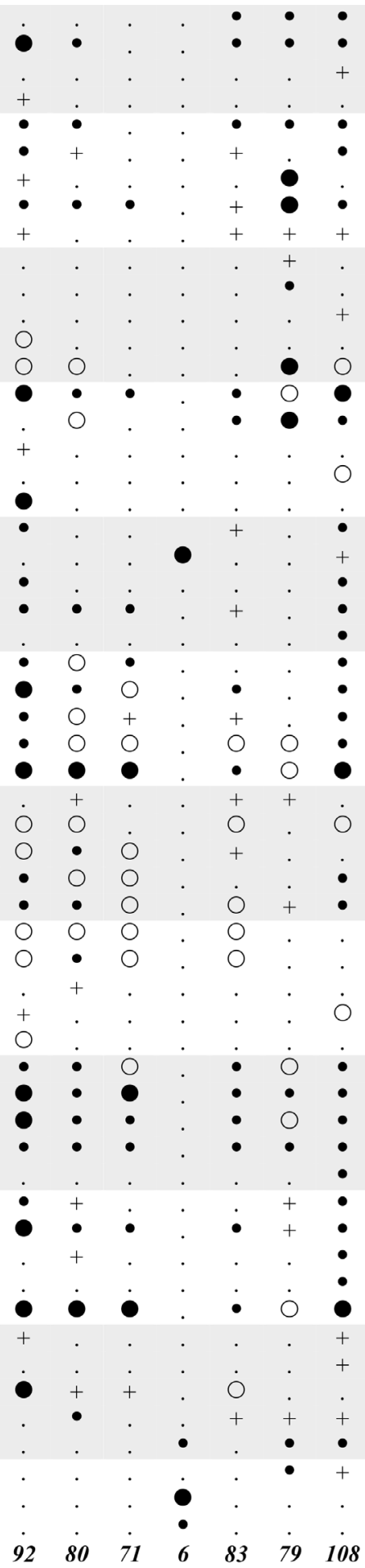




\section{Irodalom}

Malicky, H. 2004: Atlas of European Trichoptera. Second Edition. - Springer, pp. 359.

Malicky, H., Waringer, J., Uherkovich, Á. 2002: Ein Beitrag zur Bionomie und Ökologie von Platyphylax frauenfeldi Brauer, 1857 (Trichoptera, Limnephilidae) mit Beschreibung der Larve. - Entomologische Nachrichten und Berichte (Dresden) 46 (2): 73-80.

Neu, P., Malicky, H., Graf, W. \& Schmidt-Kloiber, A. 2018: Distribution Atlas of European Trichoptera. Die Tierwelt Deutschlands 84, pp. 891.

NóGRÁDI, S. 1985a: Caddisflies of the Barcs Juniper Woodland, Hungary (Trichoptera). A Barcsi borókás tájvédelmi körzet tegzesfaunája. - Dunántúli Dolgozatok Természettudományi Sorozat 5: 117-134.

NóGRÁDI, S. 1985b: Further caddisfly species new to the Hungarian fauna (Trichoptera). - Folia entomologica hungarica 46 (1): 129-135.

NóGRÁDI, S. 1986: New data to the caddisfly fauna of Hungary (Trichoptera). - Folia entomologica hungarica 47 (1-2): 135-140.

NóGRÁDI, S. 1988: New data to the caddisfly (Trichoptera) fauna of Hungary, II. - Folia entomologica hungarica 49: 205-210.

NóGRÁDI, S. 1992a: Five Trichoptera species new to the Hungarian fauna. - Folia entomologica hungarica 52 [1991]: 181-185.

NóGRÁDI, S. 1995: Hungarian locality data of Ujhelyi's Trichoptera collection in the Hungarian Natural History Museum. - Folia entomologica hungarica 56: 119-131.

NóGRÁDI, S. 2000: Caddisflies (Trichoptera) from the Villány Hills, South Hungary. Collection in a range without water courses. - Dunántúli Dolgozatok Természettudományi Sorozat 10: 285-295.

NóGRÁDI, S. 2001: Further data to the caddisflies (Trichoptera) of Hungary. - Folia Historico naturalia Musei Matraensis (Gyöngyös), 25: 83-90.

NóGrÁdi, S. \& Uherkovich, Á. 1988: The caddisfly fauna of the Gyöngyös Stream-system, South Hungary (Trichoptera). - A Janus Pannonius Múzeum Évkönyve 32 (1987): 15-24.

NógrÁdi, S. \& Uherkovich, Á. 1990: The Trichoptera fauna of the Zselic Downs, Hungary. - A Janus Pannonius Múzeum Évkönyve 34 (1989): 15-38.

NóGrÁdi S. \& Uherkovich Á. 1992: A Boronka-melléki Tájvédelmi Körzet és környéke tegzes (Trichoptera) faunája. - Dunántúli Dolgozatok Természettudományi Sorozat 7: 217-240.

NóGRÁdi S. \& Uherkovich Á. 1995: A Dráva magyarországi szakaszának tegzes (Trichoptera) faunája. Dunántúli Dolgozatok Természettudományi Sorozat 8: 117-137.

NóGrÁdi S. \& Uherkovich Á. 1998: Újabb eredmények a Duna-Dráva Nemzeti Park Dráva menti területei tegzes (Trichoptera) faunájának kutatásában. - Dunántúli Dolgozatok Természettudományi Sorozat 9: 331-358.

Nógrádi, S. \& Uherkovich, Á. 1999: Protected and threatened caddisflies (Trichoptera) of Hungary. Proceedings of the 9th International Symposium on Trichoptera: 291-297. Faculty of Science, University of Chiang Mai, Thailand.

NóGrÁdi S. \& UhERKovich Á. 2002a: Magyarország tegzesei (Trichoptera). - Dunántúli Dolgozatok Természettudományi Sorozat 11: 1-386.

NóGrÁdi, S. \& UHERKovich, Á. 2002b: On the caddisflies (Trichoptera) from the catchment area of the rivers Mura and Kerka, Southwest Hungary. - Somogyi Múzeumok Közleményei 15: 129-144.

Nógrádi S. \& Uherkovich Á., OlÁH, J. 1999: The caddisflies (Trichoptera) of the Aggtelek National Park, North Hungary. - The fauna of the Aggtelek National Park, p. 383-393.

Nógrádi, S., Ujhelyi, S. \& Uherkovich, Á. 1985: Fundamental faunistic data on caddisflies (Trichoptera) of South Transdanubia, Hungary. - A Janus Pannonius Múzeum Évkönyve 29 (1984): 37-48.

Uherkovich, Á. 2004: Further studies on the caddisflies (Trichoptera) of the water system of rivers Mura and Kerka, Southwest Hungary. - Folia Historico naturalia Musei Matraensis (Gyöngyös) 28: 187-194.

Uherkovich, Á. 2005: Further faunistic results of the caddisfly (Trichoptera) examinations of the Dráva region, South Hungary. - Folia Historico naturalia Musei Matraensis (Gyöngyös) 29: 165-168.

Uherkovich, Á. \& NóGrÁd, S. 1992a: The Trichoptera fauna of Magyarszombatfa, West Hungary. - A Janus Pannonius Múzeum Évkönyve (1991) 36: 13-30.

Uherkovich, Á. \& Nógrádi, S. 1992b: Some data to the Trichoptera fauna of Drava river, Hungary. Somogyi Múzeumok Közleményei 9: 269-278.

Uherkovich, Á. \& Nógrád, S. 1997a: Platyphylax frauenfeldi Brauer, 1857 (Trichoptera, Limnephilidae) in Hungary. - Braueria 24: 13-14. 
Uherkovich, Á. \& NóGrÁd, S. 1997b: Studies on caddisflies (Trichoptera) communities of larger rivers in Hungary. In: Holzenthal, R. W. \& Flint, O. S., Jr.: Proceedings of the 8th International Symposium on Trichoptera, 1995. Ohio Biological Survey, Columbus, Ohio, p. 459-465.

Uherkovich, Á. \& Nógrádi, S. 2001: The Trichoptera of the Szigetköz, upper Hungarian Danube Region (Northwest Hungary), I. Compendium of the faunistical researches. - Folia Historico naturalia Musei Matrensis (Gyöngyös) 25: 91-110.

Uherkovich, Á. \& Nógrádi, S. 2006: Caddisflies (Trichoptera) of the Mecsek Mountains, South Hungary. - Natura Somogyiensis 9: 289-304.

UjHeLYi S. 1981a: A Barcsi borókás recésszárnyú (Neuroptera) és tegzes (Trichoptera) faunájának alapvetése. - Dunántúli Dolgozatok Természettudományi Sorozat 2: 59-63.

UjHelYi S. 1981b: Adatok az Alpokalja szitakötő-, álkérész- és tegzesfaunájához. - Savaria, a Vas megyei Múzeumok Értesítője 11-12 (1977-78): 57-65. 
